\title{
DETERMINAGÃO DO CUSTO DE PRODUGÃO dE SUÍNOS NO ESTADO DE SÃO PAULO E ANÁLISE DE RENTABILIDADE DO SETOR
}

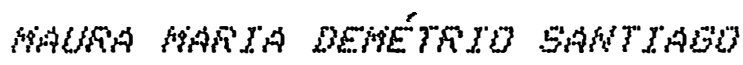 \\ Fesquisador Cientifico
}

orientador: Frof. Dr. Evaristo

Narzabal Neves

\begin{abstract}
dissertacăo apresentada à Escola superior de Agricultura "Luiz de Queiroz", da Universidade de Săo Faulo, para obtenço do titulo de Mestre em Agronomia, Area de Concentracăo: Economia Agrária.
\end{abstract}

\author{
$F$ J. F A C I C A B A \\ Estado de São Faulo --. Brasil \\ Maio -1989
}


Santiago, Maura Maria Demétrio

S235d Determinação do custo de produção de suínos no Estado de São Paulo e análise de rentabilidade do setor. Piracicaba, 1989.

$152 \mathrm{p}$.

Diss.(Mestre) - ESALQ

Bibliografia.

1. Suíno - Custo de produção - São Paulo (Estado) 2. Suinocultura - Rentabilidade - Análise I. Escola Superior de Agricultura Luiz de Queiroz, Piracicaba

CDD 338.1764 


\section{DETERMINACÃO DO CUSTO DE PRODUGÃO DE SUÍNOS NO ESTADO DE SÃO PAULO E ANÁLISE DE RENTABILIDADE DO SETOR}

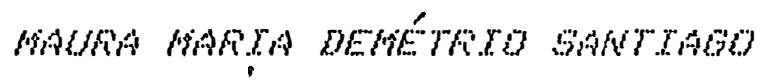

Aprovado em: 03.05 .1989

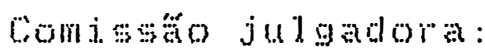

Frof ror. Evarato Marabad Neves ESALQ Q USF

Frot. Mr. Fedrou. Marquess ESPLIL Q Q U F

Frot. Lum. Valdomiros. Mada $\operatorname{ESALOMSOF}$

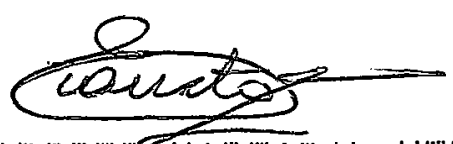

Frof. Mr. EVARTSRO MARZABAl. NEVES

Qr jentador 
Dedico

Aos meus pais, Lourdes e Mauricio (en memória), pela heranga maior que me deixaram de amor aos estudos.

As criancas, Mauricio, Ana, Fenata, Gabriel e Carolina, pelas licóses de esperanga.

A Ileus, meu guia de todas as horas, meu consolo constante. 


\section{AGRADECIMENTOS}

Ao comefarmos o curso de mestrado tinhamos como meta principal o aprofundamento dos conhecimentos teóricos em economia rural, porém, no processo que se estendeu, desde o inicio desse treinamento até a elaboracăo final deste documento, recebemos além dos ensinamentos requeridos a orientacăo, apoio e incentivo de muitas pessoas e entidades, as quais gostariamos de agradecer, 5aัo E: 1 as:

Frofessores e funcionarios do liepartamento de Economia e demais llepartamentos dat ESAlLQ, em especial ao Frofessor [r. Evaristo Marzabal Neves (orjentador e amigo), Frofessor mir. Fedro U. Marques, Frofessor lir. Valdomiro s. Miyada, Frofessor Adriano J. K. U. Azevedo Filho e Estudante de Agronomia Alivinio de Almeióa.

Jkuyo Kyuana, Joaquim Bento de $S$. Ferreira Filho, Lister Corvalan Latapia e Maria Xénia Corvalan Latapia, amj.gos e colegas do curso de mestrado. 
Lucia Maria da Silva cresponsável pelo árduo trabalto de levantamento de campos, Luz Henrjaue de oliveira Fiva, Luiz Moricochi, Maria de Lourdes Sumiko Sueyoshi, Alceu lionadelli, Albino zirlis, Carlos fioberto Bueno Ferreira, Benedito Barbosa de Freitas, Fiosa haria Fescarin Fellegrini, Afonso Negri Neto e Yuli lvete: Hiazaki de Toledo, amigos e colegas do Instituto de Economia Agricola que nos auxiliaram, fornecendo-nos achegas.

Funcionárias do Servico de Eibljoteca e: liocumentacăo do Instituto de Economia Agricola que durante muito tempo nos deram assistência, cuja bibliotecaria Aguri Sawatani Negri fez a cuidadosa revisăo bibliogräfica.

Siumara Assis [uarte dos Santos, Sueli Aparecida Cunha e vilma Aparecida $S$. Fi. da Silva que executaram o competente trabalho de digitacăo do texto.

Nosso maior reconhecimento ao engenheiro agronómo Fiosárjo Fernando Arcuri e veterinária ceci. Argenirino pelas valiosas informacóes técnicas prestadas.

Finalmente agradecemos ao Instituto de: Economia Agricola e Empresa Brasileira de Fesquisa Agropecuaria 


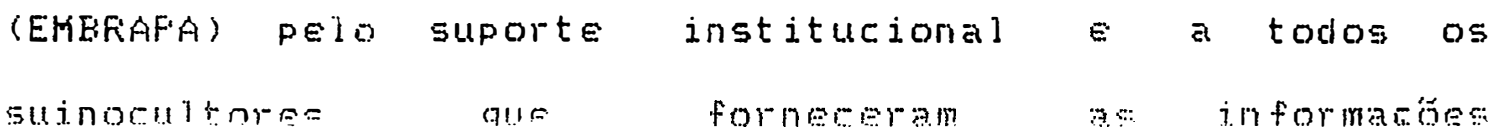
imprescindiveis para a consecucăo deste trabalho. 


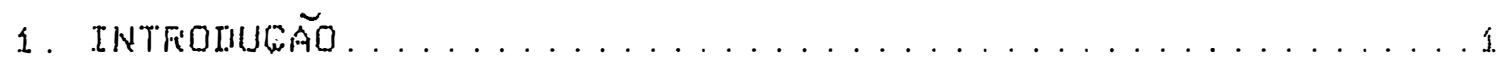

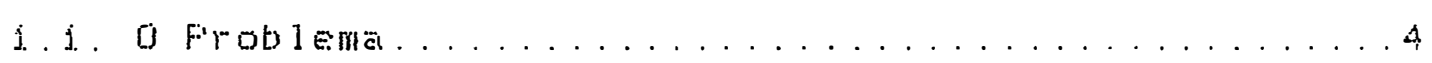

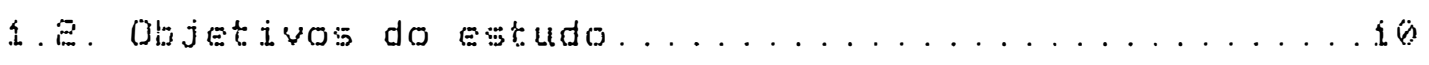

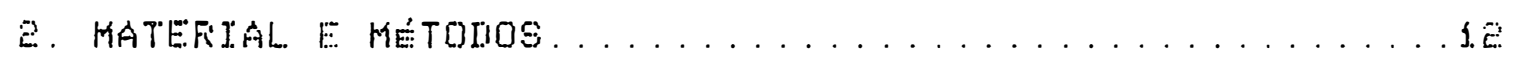

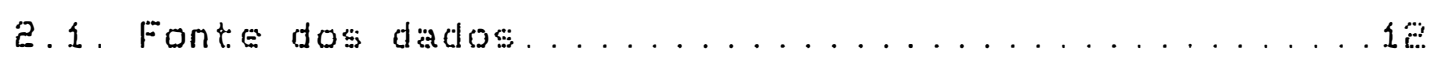

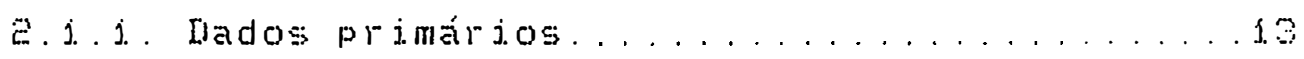

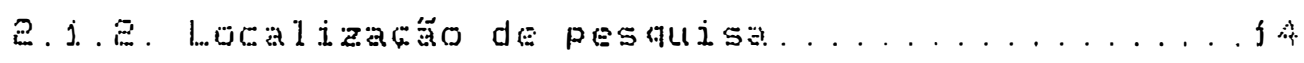

2.1.3. Caracteristicas da unidade pesquisada. . . . is

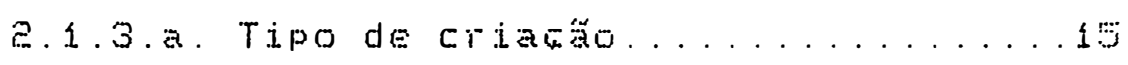


viii

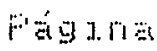

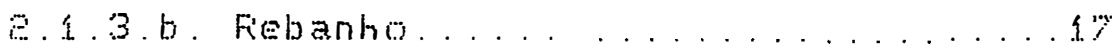

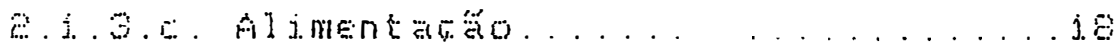

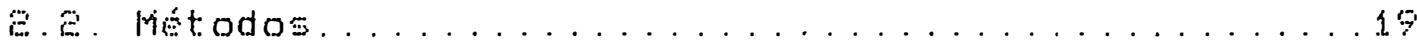

c.e.... Método de cáleulo do custo de producăo....19

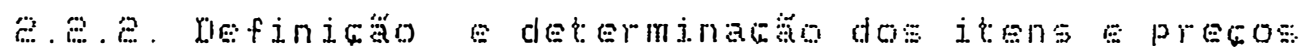
constantes das estimativas dos custos de produrgo . . . . . . . . . . . . . . .

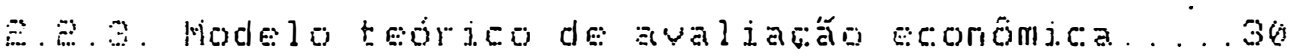

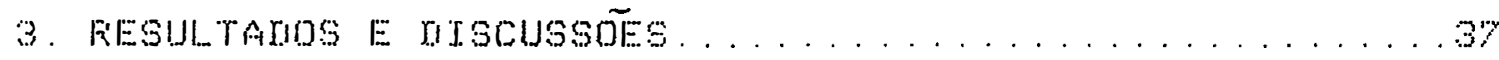

3.1. Anälise dos custos anualizados. . . . . . . . . . . . .

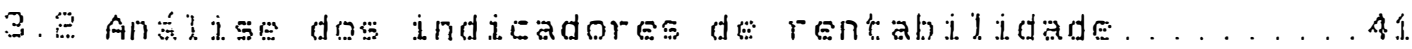

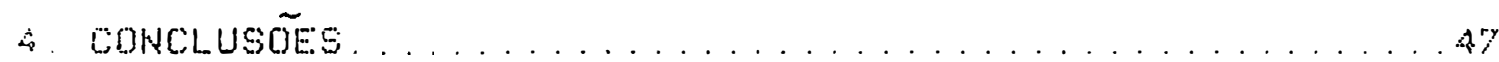

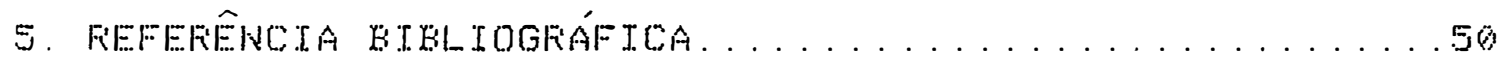


Prigina

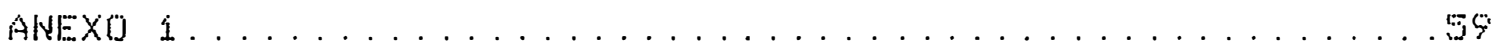

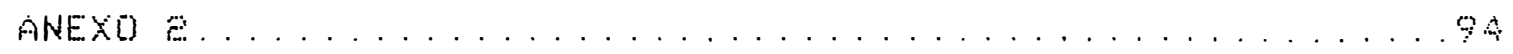

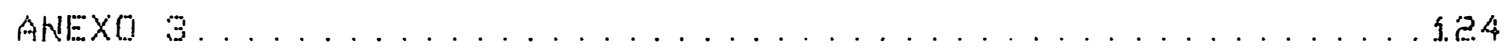

ANEXO

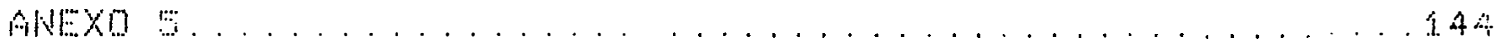




\section{DETERMINACÃO DO CUSTO DE PRODUCÃO DE SUÍNOS NO ESTADO de são paUlo e anÁlije de rentabilidade do SETOR}

Autora: Maura Maria llemétrio Santiago Orientador: Frof. Ir. Evaristo Marzabal Neves

\section{RESUMO}

$$
\text { Este estudo se propos a determinar as }
$$
estimativas de custos de producáo tecnifirada de suinos nas regiöes de Eraganca Faulista, Firacicaba, Ourjuhos e Avaré. Concomitantemente, procedeu-se a análise de rentabilj.dade do setor produtivo, através de alguns indicadores como valor atual, "payback period"(prazo de recuperaz̆o de capital) simples e econömico, relaráto beneficiolcusto e taxa interna de retorno. 
Tendo em vista a grande importáncia do arracoamento na producăo de suínos, simularam-se para

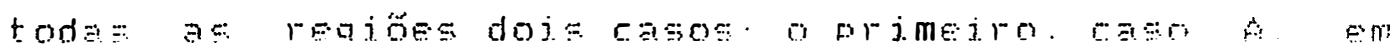
que se usa racáo formulada ä base de concentrado e milho e o segundo, caso B, onde se utiliza de racĭo de custo minimo formulada à partir de prémix vitaminicomineral.

Fartindo-se de um levantamento de campo realizado nas regiöes citadas, nos anos de 1986 e 1.987, chegou-se aos coeficientes técnicos da suinocultura, que permitiram a estimativa deralhada de custos referentes às fases de estabilizacão e producão efetiva da atividade.

Utilizando-se de metodologia baseadi na teoria de investimentos em bens de producăo atualizaram-se os custos por arroba de suino terminado, apropriados para um horizonte temporal estimado em 1.5 anos, a diferentes taxas de atratividade.

Os resultados mostram que os menores custos foram observados na regiăo de Braganga fiaulista, que săo em média $8 \%$ menores que os registrados em Firacicaba e $7 \%$ inferiores aos constatados em Ourinhos e Avaré. Em todas as localidades estudadas o caso E de alimentacáo mostrou custo inferior, comparativamente ao caso $A$.

Do mesmo modo, obtiveram-se indicadores de rentabilidade superiores em Braganga fraulista, em comparacăo às demais regiöes. Os valores atualizados 
encontrados para os casos em questáo for am positivos 6 a relacăo beneficjorcusto superior a um. o payback

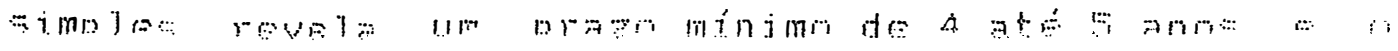
economico amplia o prazo de recuperactáo do capjotal para até anos. As taras internas de retorno indicam valores de $20,91 \%$ a $2.7,64 \%$ nos projetos do caso $A$ e de: $20,72 \%$ a 32, 32\% nos projet:os do caso bi. 


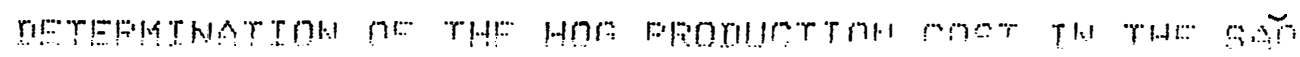

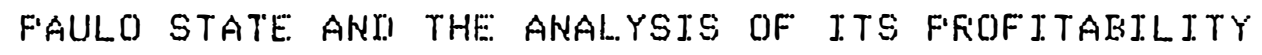

Author: Maura Maria llemétrio Santiago

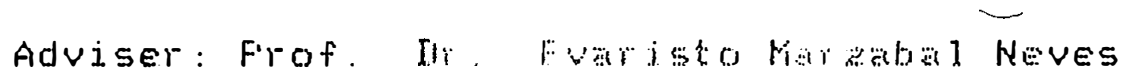

SUIKITARYY

This research determined the hog production cost estimates for the Braganca Faulista, Firacicaba, Ourinhos and Avaré regions, and its profjtability, benefitcost ratio, payback period and internal rate of return.

Two cases were considered: Case A - diets formulated with corn and concentrate, and case B .... diets formulated with minimun cost feed formulation method, using vitamin-mineral premix and other ingrediento.

A sample survey was developed during 1.986 and 4987 in order to obtain the technical coefficient: that were used to estimate the production cost of the effective production and sector stability. 
The production factor investiment theory was utilized to evoluate the cost in a fifteen year horizon alan. under different return rates

The results pointed out that the Braganca Faulj.sta regjon had the lowest cost which was, jin mean, $7 \%-8 \%$, lower than those observed in Ourinhos, Avaré and Firacicaba. Further more, the cost for the Case 1 was lower than the one for the Case A.

$$
\text { braganca waulista showed the highest }
$$

profitability. The benefit/cost ratio was greater than 1. The project simple payback was around \& to 5 years, while the economic payback was around "y years. For the Case $A$ the jnternal rate of return was around $20,91 \%$ and $27,64 \%$ and for the Case $b$ the internal rate of return was around $25,72 \%$ and $32,32 \%$. 
1. INTRODUCÃO

Atualmente, fato observado ao nivel mundial, é a tendência na diversificacăo do consumo de proteinas de origem animal. Além disso, os acréscimos observados nesse consumo săo, notadamente nos paises da Europa, decorrentes do incremento na demanda da carne suina, comparativamente à carne bovina.

Estatisticas mundiais indicam que, $\in m$ 1987, foram produzidas 160.712 milhöes de toneladas de carne, com as de suinos, bovinos, aves $e$ ovinos - caprinos participando, respectivamente, em relatăo a esse total com: $38,7 \% ; 31,07 \% ; 21,90 \% \in 5,38 \%$ ( $F A O$, vários anos)

É importante dizer que essa alteracăo verificada no perfil da producăo mundial de carnes, a partir de meados da década de setenta, foi ocasionada pelos decréscimos na producăo de carne bovina $e$ o desenvolvimento dos setores de carnes ditas alternativas, principalmente de aves, suinos, ovinos e caprinos (TFIOCOLLI \& WEDEKIN, 198. ).

- crescimento dos setores de animais de pequeno E médio porte fundamentou-se năo só na incapacidade da producăo de carne bovina atender à crescente demanda, como, também, pelo fato do mercado mundial passar, a partir de 1977/78, a dispor de elevada producăo de grăos 
forrageiros, ocasionando custos de arracoamento

decrescentes. Somam-se a esses incentivos de mercado a incorporacăo de tecnologias modernas nesses setores

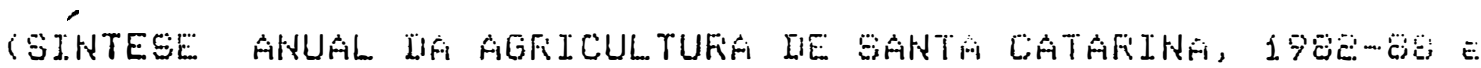
TFOCOLLI \& WEDEKIN, 1981).

Farticularmente, o aumento da importância da suinocultura no cenário de carnes, deve-se, entre outras coisas, a capacidade de resposta, a curto prazo, a estimulos à producăo, haja visto sua elevada prolificidade e rápida adaptacăo aos aperfeicoamentos zootécnicos na al imentacăo, manejo, etc.

A criacăo de suínos, também, constitui um meio indireto de obterem-se melhores precos para alguns produtos agricolas como: milho, soja $E$ mandioca. É ainda, um excelente meio de aproveitamento dos subprodutos agricolas e dos residuos industriais, como soro de leite $e$ outros, transformando-os em proteina animal.

Com o surgimento de outras fontes mais econômicas de producăo de óleo comestivel, incentivou-se o melhoramento genético das espécies voltadas para a producăo de carne mais magra, e atualmente o suino tipo carne já substitui o porco tipo banha nas criacóes industriais $e$ tecnificadas. 0 porco tipo carne(i)

(1) Seguño MIYALA \& LAVORENTI(1985), "O porco tipo carme é definido como um animal que pesa de 90 a $100 \mathrm{~kg}$, aos seis meses de idade; gasta, no máximo, $350 \mathrm{~kg} d e$ alimento para produzir lookg de peso vivo e apresenta na carcaca as seguintes caracteristicas: espessura do toicinho máximo de $3,5 \mathrm{~cm}$; olho de lombo - mínimo de 22cme e comprimento da carcaca - minimo de $75 \mathrm{~cm}$." 
apresenta vantagens comparativas em relacto aos animais tipo bantia, quanto à precocidade, conversăo de alimentos e rendimentos de carne na carcaca.

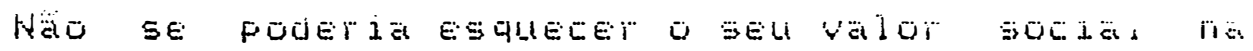
medida em que é um fator de fixacăo do homem no meio rural, principalmente quando explorado em regime de integracăo, ou através de cooperativas, com o emprego de măo de obra familiar (SOUZA et ali., 1.979). 
1.1 C Probleme

Apesar da importância económica d: exploracăo suinicola săo bastante escassas as informacŏes sobre o setor, sendo de consenso geral que uma das grandes lacunas refere-se aos estudos sistematizados e especificos do empreendimento suinicola ao nivel de agricultor, angulo importante no planejamento econômico-.financeiro da suinocultura para empresas ou regiöes especificas.

Os estudos existentes nessa área restringem-se basicamente a regiăo sul do pais, podendo-se citar os de: GASTAL \& AFiÁ́JO (1965) E SELBACH (1971) quE abordaram tópjcos especificos sobre a suinocultura como: produtividade da măo-de-obra, custo de alimentacăo, relactóo de precos porco-milho, etc.

Fosteriormente GOMES (1976), no Fio Grande do Sul, analisou os custos de producăo de suinos em um grupo de produtores, realizando uma análise comparativa de efjciêncja, entre exploraçö̌s com menores custos médios e as de custos médios mais elevados. Lientre os resultados obtidos, observou que o custo variável médio, representou cerca de $88,9 \%$ do custo total, com a alimentaço partjcipando com $77,8 \%$. As benfeitorias, mäo de obra, juros sobre o rebanto, outros gastos másuinas participaram com, respectivamente: $8,1 \% ; 6,8 \% ; 3,4 \% ; \quad 2,8 \%$ e $1,9 \%$ 
Uma pesquisa realizada pela Empresa Brasileira

de Fesquisa Agropecuaria (EMEFAFA, 19\%9) determinou as caracteristicas da suinocultura em Santa Catarina,

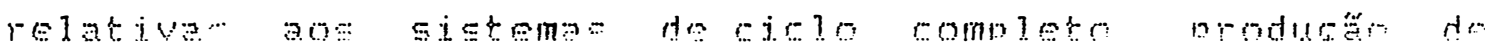
leitónes e terminacăo de leitöes. Em cada sistema, os criadores foram classificados em 3 niveis tecnológicos: baixo, médio e alto.

Na ciassiticacăo de alta tecnologia dever-se-ía atender aos seguintes requisitos: 8 leitónes nascidos por parto; mortalidade de e ieitöes por leitegada; zkg de peso minimo do leităo desmamado aos 35 dias; $10 \mathrm{~kg}$ de peso minimo do leităo desmamado aos 42 dias; $12 k g$ de peso minimo do leităo desmamado aos 56 dias $e 7$ meses de idade máxima de abate.

Ds dados provenientes desta pesquisa, compatibilizados elou combinados com informacóes obtidas em trabalho de acompanhamento de propriedades suinjicolas, permitiram a Frotas (1980) determinar o custo de producăo de suinos para o Estado de Santa Catarina, divulgar os Gritérios de avaliagăo $e$ os valores utilizados. A participacăo dos custos variáveis médios foj de $92,15 \%$, com a alimentacăo sendo responsável por $72,71 \%$ do custo total médio.

Segundo um estudo para o Espirito Santo, a Empresa Brasileira de Assistência Técnica e Extensăo fiural 
(EMFFATEFi, j980) caracterjzou o produtor de cj.lo completo, como aquele que se utilizava do confinamento

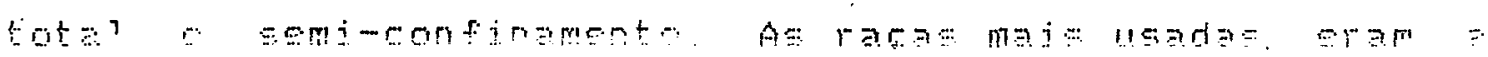
Large White, a liuroc, Landrace e o cruzamento entre elas. A aljmentaçăo era baseada ent racăo comercjal para lej.tóes e racăo formulada à partir de concentrado protéico $e$ milho, para as categorias: reproducào, recria e terminacăo. D desmame era realizado entre os 42 e 49 dias de idade dos leitöes. O programa sanitário seguía as vacinacóes periódicas, desinfectăo das instalacóes e. profilaxia das verminoses.

Ds indices zootécnicos observados foram os seguintes: 9 leitóes nascidos vivos por parto; $15 \%$ de: mortalidade até o desmame; $42-49$ dias de idade na desmama; 1,8 partos por porca por ano; $5 \%$ de mortalidade da desmama ao abate; 13,1 . animais terminados por porca por ano; 200 dias de idade no abate; 90 a lo0kg de peso no abate e $33 \%$ como taxa de reposiqŭo das fêmeas.

As recomendacóes técnicas do trabalho tinham como objetivo atingir os seguintes indices: 9,5 leitóes nascidos vivos por parto; 42 dias de idade à desmama; 2 partos por porca por ano; $3 \%$ de mortalidade da desmama ao abate; 15,6 terminados por porca por ano; 180 dias de idade no abate; lookg de peso no abate e $30 \%$ de taxa de reposicăo de fêmeas. 
Essas informacöes obtidas junto a EMEFAF'A(1979) (E EMFATEF(1980) serviram de parâmetros para a presente pesquisa na definicăo do sistema de criacăo e grau de tennificarat

OLIUEIFA \& KONZEN (1981) analisaram a evolucăo da rentabilidade na producăo de suinos no fío Grande do Sul, no periodo 1970 - 78 e observaram uma variacăo grande na lucratividade, determinada principalmente, pelat combinacăo dos preços do milho dos concentrados com o preqo recebido pelo produto.

- F'FIOTAS \& TALAKINI (3.982) verificaram
existência de diferencas nos resultados técnicos e económicos da atividade suinicola praticada no Estado de Santa Catarina, em três escalas de producăo (pequena, média $e$ grandel. Também identificaram as variáveis que determinam estas diferencas, utilizando-se do critério de comparacăo da margens brutas. As propriedades de tamanho médio, com aproximadamente 17 matrizes, proporcionaram maiores margens brutas, em funcăo do melhor desempenho zootécnico verificado nessas propriedades. Concluiram ainda que nessas propriedades houve melhor alocacăo dos recursos de măo de obra.

COSTÁ et alij. (1985) estabeleceram um sistema de Eálculo do custo de producăo de suinos no Estado do Faraná. Neste trabalho săo discutidạs as dificuldades em 
se identificar a tecnologia media utilizada na suinocultura paranaense, tendo en vista que esta atividade que pode ser desenvolvida com a utilizacáo de

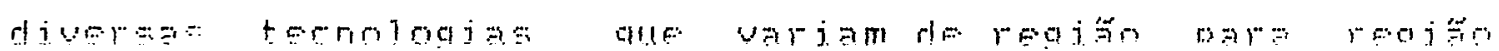
dentro do Estado e de produtor para produtor, dentro de determinada regiăo.

FROTAS et alii (1.986), através da programacăo linear, avaliaram os impactos das variacóes na relacăo de disponibilidade de terra/măo de obra e crédjto na expansăo da atividade suinicola. Os resultados mostraram que a jutensidade de producăo de suínos, en pequenas propriedades, parece estar estreitamente vinculada aे disponibilidade de măo-de-obra, e que uma politica de precos mínimos para o suino poderia ter impacto favorável na reducăo do éxodo rural das regiốes estudadas. Ilada a sensibilidade observada das atividades de suinocultura, em relagăo aos pregos praticados, concluiram que é necessário submeter as novas tecnologias, eventualmente geradas pelas pesquisas, a uma avaliag:ăo econômica antes de passar à etapa de difusăo. Um fato comentado é de que as tentativas para a reducăo do custo médio săo dificultadas por limites físicos da taxa de conversăo alimentar, sendo justamente a alimentacăo o componente mais importante do custo de producăo dos suínos.

COFFEA (1986) determinou o custo de produc:ăo de suinos, na regiăo de Fartura-Săo Faulo. Fara isso 
utilizou daclos sobre rendimentos operacionais e consumo de medicamentos. racósesedemais insumos, obtidos em reuniăo com sujnocultores da regiăo. o módulo médio determinado

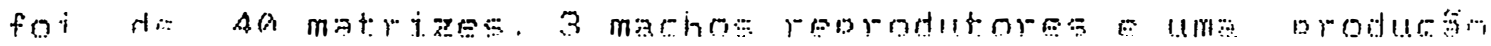
médja de: 8 animajs terminados por parto, com 2 partos/fémea/ano. Assim como nos demais trabalhos sobre custo, a alimentacăo constituiu-se no item de maior peso nos custos totais, contribuindo com $78,88 \%$.

No tocante aos custos de producăo, ainda que se constituam em assunto bastante discutido, destacam-se a:s dificuldades inerentes ao cálculo dos mesmos dadas as situacŏes de multiplicidade e interdependência das producóes agricolas, sensibilidade dos custos às condicöes particulares de cada ano, superposicăo numa mesma empresa de ciclos de producăo de duracöes diferentes e falta de registros contabilisticos.

Como consequếncia desse quadro, constata-se a inexistência de um consenso sobre ura metodologia clara e precisa de apropriacăo. Iliante disso, os estudos de custos acabam dependendo do tipo do problema que se queira resolver, do interesse e critério pessoal E, consequentemente, näo se tem uma linica estrutura de custo, mas inumeras, diferenciadas e muitas vezes conflitantes (BAFROS, 1965; NEVES, 1980 E NEVES \& SHIROTA, 1987).

Um outro ponto discutivel é o que ocorre no caso de atividades agricolas de longo horizonte temporal, 
referente a omissăo da dimensä́o do tempo e do problema da inflaşa nos orgamentos de custo o que dificulta o seu uso.

Tecnicamente a suinocultura é uma opgäo de atividads bera pequenos e medios produtores, no sentidn to que pode ser conduzida com exigencias minimas de área $E$ máno-de-obra, oferecendo um produto final num periogo relativamente curto. For outro lado, para que se obtenham elevados indices de produtividade, săo grandes as suas exigências em termos de capitais fixos e circulantes. Sendo assim, os produtores investem na atividade, considerando um horizonte temporal relativamente longo $e$, portanto, superior ao ciclo de producăo do animal.

For fim, fazem-se necessários estudos sobre custos que levem em consideracăo os fatores acima, e particularmente no caso da producăo de suínos, até o momento, só foram realizados trabalios pelo sistema tradicional, com cortes seccionais no tempo, definindo-se planilhas isoladas para cada ano.

\subsection{Objetivos do Estudo}

Os objetivos a que se propöe o presente estudo รสั้ว :

a) determinacăo das estimativas de custos de 


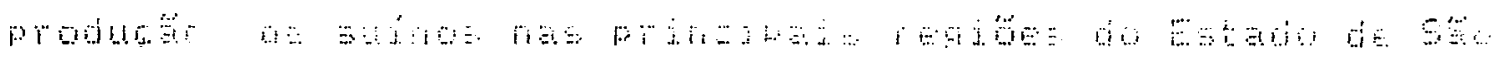

Faulo, para um horizonte temporal de is anos;

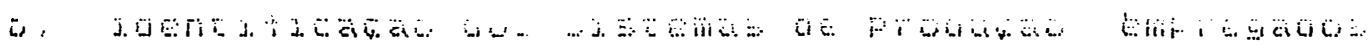

pelos produtores nas localidades de Braganga faulista,

Firacicaba, Ourinhos e Avaré;

c) em extensăo, procurou-se analisar a rentabilidade

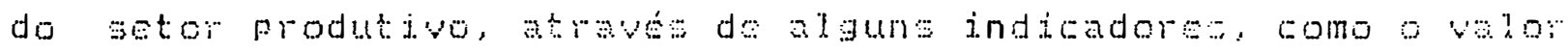
atual. "payback period" (perjodo de recuperacăo do capital) simples e econômico(2), relaçăo beneficiolcusto taxa interna de retorno (situacöes deterministicas); E:

d) adicionalmente, em anexo, a guisa de informacóes, procurou-se caracterizar a suinocultura no mundo, Brasil e Estado de Sáo Faulo, que constituem elementos importantes e auxiliares para o conhecimento dos sistemasi de producăo predominantes e geracăo das planilhas de custos que perfazem os objetivos deste estudo.

(2) Nesse caso os elementos dos fluxos de caixa sáo atualizados, estabelecendo-nse um custo ao dinheiro. 
2. MATERIAL E MÉTODOS

\subsection{Fonte dos dados}

Com o objetivo de determinar os coeficientes técnicos utilizados na suinocultura tecnificada no Estado de Săo Faulo, foi realizado um levantamento de campo nos anos de 1986 e 1987 nas IIvisóes Regionais Agricolas (IIJfiAs) de Marjlia, Sorocaba e Campinas. Estas regiŏes, segundo o Instituto de Economia Agricola, apresentam juntamente com a lira de fibeiräo freto, as maiores concentracóos de suinos do Estado.

A priori, foi definido que as unidades amostradas deveriam adotar um conjunto de praticas relativas a suinocultura tecnificada, no sentjido de que: produzissem o suino tipo carne, que os animis fossem criados confinados ou semi-confinados, recebessem alimentacăo balanceada e observados os devidos cuidados higiênicos e de manejo. 
A seguir, partindo-se dos cadastros de:

informantes do Levantamento Mensal de Fregos Fecebidos pelos Agricultores no Estado de Săo Fiaulo, de suinocultores fornecidos pela Federară de Aqricultura do Estado de Săo Faulo (FAESF) e de indicacóes dos técnicos da Woordenadoria de Assistencia Tecnica Integral (cart), das casas de Agricultura nas regióes citadas, foi determinada uma amostra intencional de suinocultores, que atendesse às exigências pré-determinadas de tecnificacăo da atividade.

\subsubsection{Dados primários}

Fara o levantamento dos dados primários da pesquisa em questăo elaborou-se um questionário especifico com questöes referentes às caracteristicas do produtor e da propriedade, comercializacăo, composigăo e manejo do rebantio, indices de produtividade, mäo-de-obra, benfeitorias e máquinas e equipamentos utilizados nä suínocultura. o método de levantamento foi o de entrevista direta junto aos produtorey. 


\subsubsection{Localização da pesquisa}

As liffis abrangidas pela pesquisa foram as de:

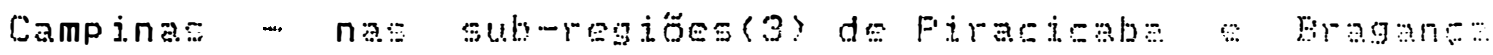
Faulista; Sorocaba - na sub-regiăo de Avaré e Marillia -. nas sub-regiöes de Bernardino de Campose Ourinhos. No tocante a esta litima IIfiA resolveu-se agrupar as duas sub-regiótes estudadas em uma linica regiăo (Ourinhos), visto que anteriormente Bernardino de Campos pertencia a sub-regiăo de Ourinhos.

Em anexo, săo apresentadas $e$ analisadas separadamente as informacóes referentes a cada uma das sub-regióes estudadas (ANEXO 2).

É preciso assinalar que muito embora o objetivo principal deste estudo tenha sido o de levantar os coeficientes técnicos para a determinacăo dos custos de producăo, as informacões aqui apresentadas permitirăo oferecer um diagnóstico preliminar do processo produtivo dos suinocultores, com tecnologia avancada nas regióes estudadas. Fornece ainda subsidios para estudos que se

(3) Ile acordo com a estrutura administrativa da secretaria da Agricultura e Abastecimento do Estado de Sáo Faulo as sub-regiöes correspodem às llelegacias Agrjcolas $(I \mid A)$. 
fazem necessairios, face a inexistência em Sắ Faulo de informacóses sobre a organizacăo e comercializacăo da producăo suinicola ao nivel de produtores.

Apesar de certa similaridade encontrada, en
termos de indjes de produtjujdade nas localjdades da
pesquisa, procurou-se estudar separadamente cada uma
dessas regióes a fim de se detectar se as diferencas
observadas, relativas aos indices de mortalidade e idade
de abate, influem significativamente sobre os custos.

\subsubsection{Caracteristicas da unidade pesquisada}

For simplificacăo $e$ dadas as dificuldades
encontradas no dimensionamento das granjas, optou-se por
um módulo, para este estudo, com 100 matriaes 67 cachacos.

2.1.3.a. Tipo de criacão

Escolheumse um sistema de criacăo totalmente
confinado, para o qual se dispunha de uma planta com as
instalacótes para cada categoria animal.


Segundo GASFAF (s.d.), a titulo explicativo, de acordo com o grau de confinamento, existem três sistemas: de criacăo: extensivo, intensivo e misto.

No sistema extensivo a criacăo fe fejta a campo, com auxilio de abrigos rusticos. Săo necessários grandes áreas com rebanhos de matrizes inferiores a jo porcas. A producăo é caracterizada por safras estacionais, havendo também épocas pré-determinadas para monta, parjŏ̌o terminąăo.

No sistema intensivo todas as etapas da criacăo - cobertura, gestacăo, paricăo, aleitamento, recria e acabamento săo realizadas em instaląŏ́es apropriadas, sem permitir o acesso dos animais a pastos ou piquetes gramados. As instalacóes $e$ o conjunto de práticas criatórias adotadas têm por finalidade realizar todas as fase $\Rightarrow$ da criaç̃o em regime de confinamento total. É um sistema recomendado principalmente para o aproveitamento de pequenas áreas, em regióes supervalorizadas, nas proximidades dos centros populosos, $€$ onde hajam boas fontes de residuos industriais, etc.

Ainda, conforme GASFAF, num sistema racional de exploracăo intensiva há possibilidade de se obterem melhores indices de produtividade, muito embora a măo de obra $€$ as instalacões atinjam um custo mais elevado. Com a necessidade de suprir com uma alimentacăo rigorosamente 
equilibrada as exigências nutricionais anteriormente propiciadas pelo sol. terta e pastos.

c) sistema misto compreende a combinacăo dos dois

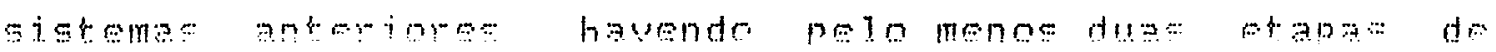
criacăo, gestacăo e recria, em que os animais devem ter acesso a pastos ou pi. quetes gramados.

No entanto, constata-se atualmente que neste sistema também denominado de semi-confinado, só os reprodutores (machos e fêmeas) săo mantidos em piquetes.

\subsection{3.b. Rebanho}

A estabilizacăo do rebanho foj. fejta, supondo-se um esquema de producăo semanal e que as primeiras 14 semanas de implantacăo do projeto foram utilizadas para a construcăo das instalacŏos.

Sempre que se fez necessálio complementaram-se: as informacóes, levantadas junto a produtores, com aquelas provenientes de outras fontes, via literatura existente ou informacóes de técnicos ligados ao setor.

Tendo em vista a grande varjabilidade exjstente na pesquisa em termos de rebanho (número de matrizes) e portanto com diferentes necessjdades de equipamentos, măo --de-obra, etc., após a definigăo do módulo a ser 
anal isado,

propriedades que dispunham de rebanho proximo a 100 matrizes, a fim de se quantificar com precisăo os

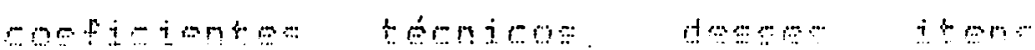

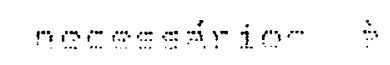

conducăo da atividade.

\subsection{3.c. Alimentacão}

Dutro ponto levado em consjderacăo foi o relativo à alimentaço. Sendo assim, definiu-se para cada regiăo duas alternativas. A primeira (caso A) em que a racăo é formulada à base de concentrado $e$ milho, $e$, a segunda, caso $E$, em que se usa racăo de custo mínimo formulada à partir de prémix vitamínico-mineral, utilizando-se. dos ingredientes mencionados pelos produtores entrevistados.

Fara fins de explicacão, conceituam-se (Fiof'FA, 1985) rafóes balanceadas aquelas que já vem prontas para serem consumidas pelo animal, e săo vendidas diretamente pelos fabricantes. Os concentrados contém a parte proteica, vitaminas e os minerais. Fara seu uso o criador deve adicionar o milho (parte enérgetica), constituindo o concentrado de 1.5 a $25 \%$ da mistura final. Os super concentrados e nucleos contem as vitaminas, os minerais 
todo calcio efóforo requerido, tornando-se necessario, portanto, o emprego conjunto do milho e fonte protéica, (farelo de soja e outros). Em geral, constituem de 4 a

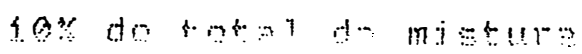

Ds prémixes vitaminicos e minerais fornecem apenas as vitaminas e os mineratis (em alguns casos, também aditivos). Deve-se, adicionar fontes enérgéticas (milho $e$ outros), ingredientes protéicos (farelo de soja e etc.), fontes de cálcjo, fósforo e: sâl.

\subsection{Métodos}

\subsubsection{Método de cálculo do custo do producão}

Fartindo-se da estimativa detaliada de custos, referentes às fases de estabilizacăo eroducăo efetivă para os casos considerados (Tabelas AA.A a AA.12 - ANEXO 4), procedeu-se a atualizaçăo dos custos por matriz $€$ aroba de suino terminado, utilizando-se de metodologia baseada na teoria de investimentos em bens de producão (Neves et alii, 1983b). 
D método para obtencăo do custo anualizado de

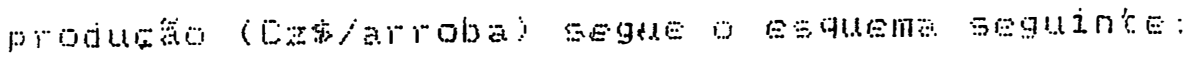

tores, onde:

Seja $C_{i j}$ uma matriz de coeficientes tēcnicos e exigēncia de $f_{\underline{Z}}$

i - corresponde aos inümeros itens referentes ao uso de insumos; aqui sição de reprodutores, māquinas e equipamentos; construção de ins. talações, etc.

j-corresponde ao ano a partir do início da atividade

Assim, cada coeficiente $C_{i j}$ representa a quantidade física do fator necessārio para o item $i$ no ano $j$.

Seja $\mathrm{Pi}$ uma matriz de preços, onde cada elemento pi representa o preço do $i$-ēsimo item da matriz $C_{i j}$. Consideram-se esses preços fi xos, em termos reais, ao longo de todo o horizonte de anālise.

Tendo em vista que foi de 15 anos o horizonte considerado como período produtivo, no caso da suinocultura, tem-se:

$$
j=0,1,2, \ldots \ldots \ldots . .14 \text {. }
$$

Define-se despesa (dij) no $i$ tem $i$, ano $j$,ao produto do preço pi pelo correspondente coeficiente fisico Cij. A matriz de despesa Dij, que resulta do somatōrio das dij, contém todas as estimativas de custos, por item de despesa, ao longo de cada ano do horizonte em questão. Isto $\bar{e}$, a matriz $\mathrm{D}$ corresponde ao produto da matriz $\mathrm{P}$ com a matriz $C$, então:

$$
\operatorname{dij}=p i \times C_{i j}
$$

Atravēs da somatōria das despesas $i$ no ano $j$, obtém-se a despe sa sj nesse ano, ou seja: :

$$
s j=\sum_{i=1}^{n} d j
$$


0 vetor de despesas $S_{j}$ representa o conjunto do despesas $s_{j}$, ano a ano. Dispondo-se das despesas anuais, procede-se ao cálculo do lor presente $V P D_{k}$ desse fluxo, para taxas de descontos alternativos ( $k$ taxas de desconto), onde:

$$
\mathrm{VPD}=\sum_{j=0}^{m} S_{j} \cdot \frac{1}{(1+k) j}
$$

Dispondo-se da estimativa anual de produção de suĩnos, ao lon go do horizonte considerado, obtēm-se um outro conjunto de valores $z_{j}$. 0 valor presente dessa produção para $k$ taxas de desconto alternativas $\left(V P P_{k}\right)$ è determinado assim:

$$
V P P_{k}=\sum_{j=0}^{m} z_{j} \quad \frac{1}{\overline{(1+k) j}}
$$

Finalmente, o custo por unidade produzida $\left(c t_{k}\right)$ resulta da di visão do valor Presente das Despesas $\left(V D_{k}\right)$ pelo Valor Presente da Produ ção $\left(V P_{k}\right)$, ambos descontados a mesma taxa, então:

$$
C T_{k}=\frac{V P D k}{V P P k}
$$

Huito embora na literatura existente näo se tenha conhecimento de trabalho aplicando esta metodologia na área de producăo animal e que possibilite comparacóces com os dados da presente pésquisa, pode-se citar o de Afifuria (1982) que estimou os custos de estratégias de: formarăo e conservacăo de pastagens em uso na regiăo Centro-deste. A finalidade deste estudo era de facilitar a visualizagăo do potencial da pecuária de corte na abertura de novas áreas da região. 


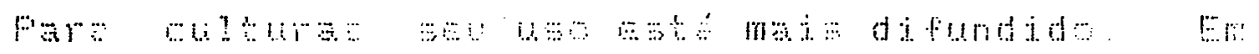

5.984, NEVES utilizou esta metodologia para a determinąăo

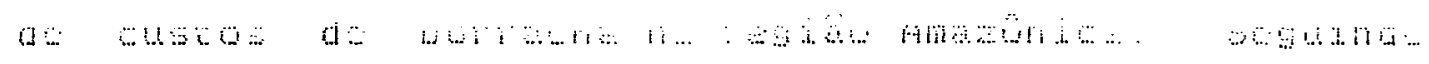

mesma linha de pesquisa Afifura (1987) determinou os custos

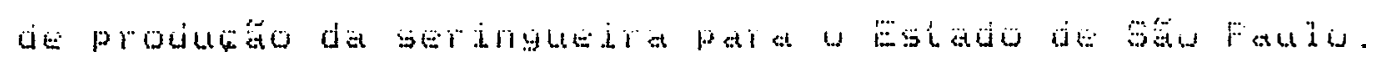

Essa mesma metodologia foj. usada nos trabaltos de NEvEs et alii (1988a), no cálculo de custos de producáo de laranja no Estado de Săo Faulo e SHIfoTA et alid. (1988) nos custos de produsăo do café nas luivisöes fiegionais Agricolas de fibeiräo Freto e Săo José do fijo Freto.

As seguintes consideracóes básieas foran utilizadas no cálculo do custo de producăo:

-.m Todos os fluxos de despesas for am expressos em cruzados de juntio de 1988 e, posteriormente, convertidos em Orks.

- As taxas de desconto usadas foram de $6 \%, 10 \%$, $12 \%, 15 \%$ e 20\% a.a, em termos reais. A taxa de $6 \%$ a.a. corresponde à remuneracăo anual das caderretas de poupanga; as de $10 \%$, $12 \%$ e $15 \%$ a.a. como uma aproximacă às taxas vigentes para o credito rural no Erasil $E$ financiamentos do mercado internacional, e a de $20 \%$ a. a., como uma taxa de mercado. 
2.อ. Definicãc E determinacäo dos ltens e precos constantes das estimativas dos custos de producão

\begin{abstract}
No cálculo dos cuscos de produsăo de suinos

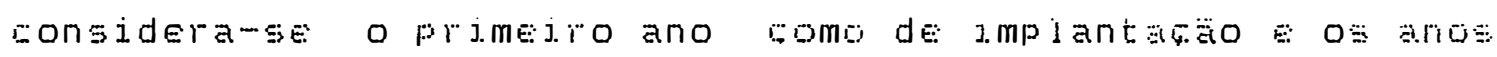
seguintes de producăo.

A fase de implantacăo corresponde ao periodo de: investimentos em benfeitorias, equipamentos, aquisicăo de reprodutores e onde ocorrerä a estabilizacăo do rebanio, após o qual ter-se-a uma producáa estavel ate o final do projeto.
\end{abstract}

Tendo em vista que grande parte dos equjpamentos possui. uma vida lítil de 15 anos foi este periodo também escoltido como horizonte temporal do presente estudo (Tabela $A 4.13, A N E \times O$ 4).

Como é usual nö projetos de suinocultura consideraram-se tanto os investimentos como todos os itens do custo em termos de matriz instalada. Ao final Estimaramse custos anualizados, acompanhando-se os indices descritos de animais terminados/ano/matriz, pol regiăo, com os respectivos pesos médios (ANEXo 己).

$$
\text { Â definic:ăo das variàejs, na fä口 de }
$$
implantaço obedeceu aos seguintes critérios: 
Investimentos em instalacões e máquinas:

... Ds investimentos em benfeitorias englobam o gastos na construcăo das instalacöes especifjcas da suinoculiura como: edificios - creche, maternidade, pré-gestacăo, gestacăo ecachacos; e recria-terminacăo. Computaram-se também os dispêndios com o reservatório de água, casas de empregados, depósito e fábrica de racăo.

0 material usado nestas construgóes $\Leftrightarrow$ alvenaria, telhas de barro e piso semi-ripado (especifico para instalacóes dos suinosi.

Os investimentos em máquinas e equipamentos refersm-se à compra dos seguintes itens: gaiolas (p)é-gestacăo, gesiacăo, maternidade creche), bebedouros, comedouros, campänulas, carrinhos para racăo, desintegrador de racăo, misturador de räắo, pulverizador costal, balanca para racăo, balanga para pesagem dos animais o motore:

\section{Aliment ą̧ão:}

Fara a determinacăo dos custos com al imentacáo dos animais usaram-se das duas alternativas alimentares maj: observadas nas proprjedades pesquisadas, ou seja: racăo fejta à base de concentradoe milho e racáa de custo 
minjmo(s) , à partj.r da premix vjtaminjcomineral.

Especificamente para este segundo caso levantaram-se os

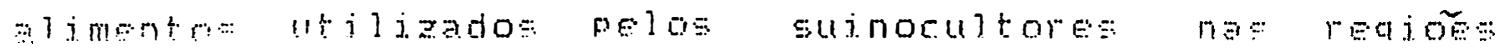
estudadas (ANEXO 2). Em seguida contactou-se uma fábrica de racóes que, de posse dos dados acima, formulou racónes balanceadas para as diversas categorias de suínos. 0 prefos utjilizados dos insumos săo referentes ao mês da junho/88.

0 consumo diário por categoria foi estabelecjdo segundo orientafóo técnica e através dos dados de estabj.l jaacăo do rebanho pôde-se chegar ao consumo anual de racáo por tipo de animal (Tabelas AA. A a AA. A, ANEXO 4). A formulacăo da rafăo à base de concentrado $e$ milho, seguiu as seguintes recomendacöes, por categoria: crescimento - $80 \%$ milho e $20 \%$ concentrado; acabamento (t:erminacăo) - - 85\% milho e 15\% concentrado; reproducăo -..

(4) lie: acordo com FEFES \& MAFQUES(1988). "A formuląä́o de racóses de custo mínimo é um problema clássico da programata lo linear. Ele consiste em, conhecidas as caracteristicas nutricionais dos alimentos, precos destes, necessidades nutricionais dos anjmais E ljmitacótes de ordem técnica e biológica, procurar combinar os alimentos de forma a se obter uma racáo com o menor custo poseível eque ao mesmo tempo, satisfaca a necessidades nutrj.cionais dos anjmais. 
$80 \%$ mitho 0 en $\%$ concentrado. Fara a categoria

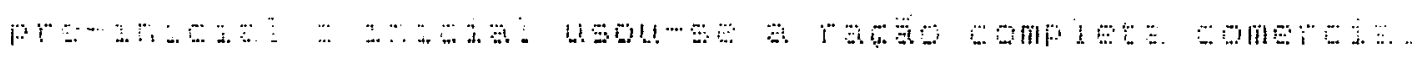
Com referêneia j racăo formulada à partir do

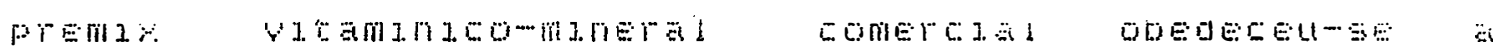
composicăo segundo a Tabela 1.

\section{Investimentos em animais:}

Fara efeito do custo de aquisicăo dos reprodutores, supos-se que eles foram comprados de uma só vez, e os precos considerados referem-se a animaja com Fiegistro de origem Inspecionado (FOI), obtidos $n$ Associafáo Faulista dos Criadores de Suinos. 0s case. estudados englobam 100 femeas 67 reprodurotes, considerando-se uma taxa de $25 \%$ a.a. de reposicăo.

\section{Terra:}

Quanto ao fator terra, admitiu-se que o mesmo serś remunerado a uma taxa de $6 \%$ ao ano. os pregos nesse caso săo resultantes das méias entre as caregorias de terra de primeira e segunda, especificas para as regiose estudadas. 


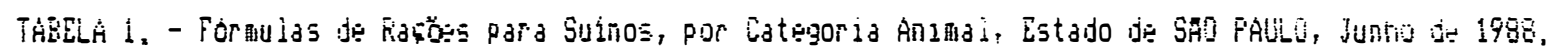
(Eg porcentagen )

\begin{tabular}{|c|c|c|c|c|c|}
\hline inge toments & nefrogus & idtisgiso & $\begin{array}{r}\text { mas } \\
\text { (ate } 20 \mathrm{~kg})\end{array}$ & $\begin{array}{r}(20-60 \text { ) } 9)\end{array}$ & $\begin{array}{l}\text { Modati } \\
\text { bokg-abate }\end{array}$ \\
\hline Futas dy ath & $\therefore, 2$ & 90.50 & $=\therefore$ & $\therefore \therefore$ & $-\infty$ \\
\hline Fareio de trigo & 8.00 & 13,60 & - & 11,000 & 13,70 \\
\hline Farelo de arroz & 10,10 & .* & 8,90 & - & - \\
\hline Fareig de soja $(46 \%)$. & 9,50 & 12,00 & 30,30 & 25,70 & 11,00 \\
\hline Farintia de carne (38\%) & 3.70 & - & - & 1,00 & 1,50 \\
\hline Tarinha de arne $(4 \% \%)$ & - & 5,10 & 2,30 & - & - \\
\hline Calejrio & 0,61 & 0,20 & 0,8 & 0,59 & 0,8 \\
\hline Sai & 0,40 & 0,40 & 0,40 & 0,40 & 2.45 \\
\hline \multicolumn{6}{|l|}{ Foliuitaginico } \\
\hline Indizaliceresionto & - & - & 0,40 & 0,40 & - \\
\hline Folivitarinico & & & $\cdot$ & & \\
\hline Acabariento & - & - & - & - & 3.8 \\
\hline $\begin{array}{l}\text { Folivitabinico } \\
\text { Reprodusăo }\end{array}$ & 0.80 & 0,20 & - & - & - \\
\hline Tot31 & 100,00 & 100,00 & 100.00 & 100,00 & 100,00 \\
\hline
\end{tabular}

Fonte: Ilados da pesquiso 


\begin{abstract}
o item măo-de-obra diz respeito a dois empregados, sendo um deles o encarregado, formada por trabalhadores permanentes e residentes na própria propriedade, conforme dados da pesquisa. Wa vaiorizacăo desses gastos optou-se pelos salários vigentes nas regióes Estudadas, incluindowse os encargos sociais para o trabalhador comum $\in$ o encarregado.
\end{abstract}

Medicamentos:

Fara o cálculo dos gastos veterinários deterininou-se através da pesquisa, as vacinas $e$ medicamentos mais utilizados, com as respectivas doses. A partir dai utilizando-se também das recomendacóes técnicas, estimou-se o consumo de cada tipo de vacina $e$ medicamento por categoria animal/ano, como segue:

- Vacina contra peste suina: matrizes - 2ml; cachacos - 2ml; leitöes (creche) - 2ml.

- Vacina contra paratifo: matrizes - 4ml; leitöes (maternidade) - $2 m l$.

- Vermifugos: matrizes - 10ml; cachacos - 10ml, leitöes - (creche) - $2 \mathrm{ml}$

- Ferro: leitóes (maternidade) - 2ml.

Com estes dados, e tendo o número de animais ein cada categoria, chegou-se ao consumo $e$ gasto com medicamentos do rebanho/ano. 
Sobre o valor encontrado nestes itens, acrescenos ur percentual de sos pare gasto com ontros medicamentos, como: indutores de parto, desinfetantes, sarnicidas, antibióticos, etc.

\section{Energia:}

As despesas com energia elétrica foram determinadas atualizando-se o valor gasto com este item nas propriedades amostradas, na época da pesquisa, através do Indice de Frecos fagos pela Agricultura no Estado de Săo Faulo. Este indice é determinado mensalmente pelo Instituto de Economia Agricola.

o mesmo método foi utilizado para a determinacão do custo de transporte e gastos com combustiveis cóleo, gasolina $\in$ álcool).

Reparos e manutencãa:

Fara o cálculo das despesas com manutencăo $E$. conservacăo aplicou-se uma taxa de $1 \%$ ao ano sobre o valor dos investimentos de instalarö́s, equipamentos e máquinas. 
Encargos financeiros:

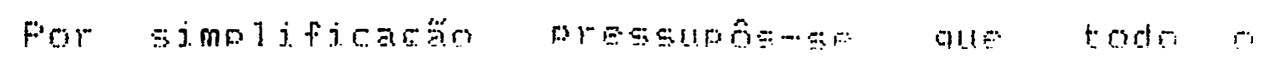

capital utilizado na presente pesquisa éproprio e, diante djsso, năo foram coṇsiderados os encargos financej.ros.

\section{Depreciacão:}

- Fara os equjpamentos que ultrapassaram o horizonte de planejamento do projeto, calculou-nse o valor resjdual, usando-se do método de depreciarăo linear (HOFFlinN et alii, 1976), supondo-se o valor de sucara igual a zero. Esses valores, săo consjderados, no liltimo ano, com sinal negativo, visto que apresentam um residuo financeiro positjuo. Llo mesmo modo, calculou-se o valor residual do rebanho, que será vendjdo ao final do projeto. No ANEXO 3 estä́o listados os preqos consjderados: no presente trabaliho.

\subsection{3 - Modelo teórico de avaliacão econômica}

É inegável reconhecer a importância da análise: económj.ca dos projetos, seja ao nivel governamental, como de empresa rural, uma vez. que se constitui eri jinstrurnento auxj.l jar na tomada de decisöes de jinvestimentos. 
Fara tanto, pode-se utilizar de diversos

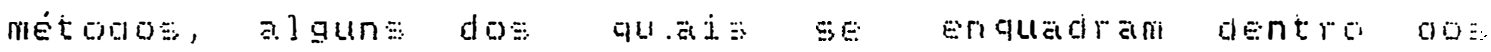
critérios que năo consideram a variacăo que o capital sofre no tempo como o "payback period" (periodo de recuperacăo do capital), razăo receita/custo e razăo receita media/custo. outro grupo, que considera a dimensăo tempo dos valores monetários, engloba os Eitérics: välor atual, taxa internä de retorno, custa ö beneficio periódico equivalente e razăo beneficiolcusto. Todos esses métodos baseiam-se na sequência dos fluxos de caixa periódicos, associada ao projeto em questăo (Fafio, 1.971).

Lleve-se lembrar que por projeto entende-se a inversăo do capital em determinado empreendimento, com a. finalidade de obtencăo de receitas (FAF'o, 1971).

Os fluxos de caixa săo valores em dinheiro que refletem as entradas e saidas dos recursos e produtos por unidade de tempo e que constituem uma proposta de investimento (NOF'NHA, 1981).

Llefine-se como fluxo monetário liquido a diferenca entre receitas e despesas.

Seja Lt com $t=0,1,2 \ldots$ No fluxo liquido de um projeto. Em geral, nos chamados projetos convencionais, caso em que se enquadra o presente estudo, Lo $\langle 0$ quando $t=0 \in \mathrm{Lt}\rangle 0$ para $t\rangle 1$, isto $E^{\prime} 0$ investimento (Lo) é feito no primeiro ano e os retornos: liquidos (l.t ), $t$ > 1 , a partir do segundo ano (NOFONHA, 1981.). 
Segundo Johnson (5), citado por NOFONHA (1981),

a dete beico envolvide na maliaro de projetoe de investimento fundamenta-se nas premissas de que o projeto deve visar a producăo de mais beneficios liquidos $E$ que tais beneficios devem ser produzidos o mais cedo possivel, em relacăo a epora do investimento inicial.

Ilentre os indicadores de rentabilidade já enumerados utilizaram-se do valor atual (UA), taxa interna de retorno(TIfi), relarăo beneficio/custo (B/C), payback simples e payback econômico.

Tem-se a seguir algumas consideracótes sobre estes indicadores.

Payback:

0 "payback" considera como elemento de decisăo o número de anos necessários para que a empresa recupere o capjal inicial investido no projeto, ou seja, compreende - espaco de tempo necessário para que a soma das receitas nominais futuras iguale ao valor do investimento inicial (NOFIONHA, 1981 E FAFIO, 1971).

(5) JOHNSON, Fi.W. Sapital_vudaeting. Ilubique, JowA, Fiendal1, Hunt Fube, 1977. Company, 2. ed., VIII, $165 p$. 
Seja I o investimento inicial, Lt o fluxo anual do projeto $e N$ o horizonte do projeto. O periodo de recuperagáo do taptitat. $n, e ́ d e f i n i d o p e l a$ reląăo:

$$
\sum_{t=0}^{n} L t=0 \quad \text { onde } t^{\prime \prime}=0,1,2, \ldots N ; N>n \text {. }
$$$$
\text { Em geral Lo }<0 \text { para } t=0 \text { e } L t>0 \text { para } t>1 \text {. }
$$

Este método reflete, quase que exclusivamente, a preocupacăo do empresário com a liquidez da empresa, năo podendo se constituir em critério decisivo para a selecăo de projetos. D inconveniente principal deste critério é o de năo considerar o valor do dinheiro no tempo.

A fim de contornar este problema, seguindo NEVES (1984) o "payback" é corrigido, levando em conta a dimensăo tempo de valores monetários, constituindo-se no "payback econômico".

Apesa: das desvantagens, é um método simples de cálculo imediato $\varepsilon$ muito usado na prática. 
Método de valor atual:

o método de valor atual reflete a soma algébrica dos valores descontados dos fluxos de caixa a ele associados é definido pela fórmula:

$$
\begin{aligned}
V A= & \sum_{t=0}^{i} \frac{L_{t}}{(1+\rho)^{t}} \\
\text { onde, } \rho= & \text { taxa de desconto relevante para a emoresa, } V A=\quad v a \\
& \text { lor atual, } L t=\text { fluxo anual do projeto e } t=\text { tempo } \\
& \text { em anos. }
\end{aligned}
$$

o fato do valor atual de um projeto ser positivo significa que, para a taxa de desconto considerada, o valor hoje das suas receitas futuras é superior ao investimento inicial ocorrido na sua implementacăo.

Taxa interna de retorno:

A taxa interna de retorno é a taxa de juros real, que torna o valor atual dos lucros do projeto igual 
a zero, ou que faz com que o valor atribuido às receitas futuras iguale ao custo de investinento. Isto é:

$$
\begin{aligned}
& \sum_{t=0}^{N} L_{t}\left(1-\rho^{*}\right)^{-t}=0 \\
& \text { onde, } \rho^{*} \bar{e} \text { a taxa interna de retorno. Lt = fluxo anual do pro } \\
& \text { jeto e } t=\text { tempo em anos. }
\end{aligned}
$$

Na avaliacăo de um projeto pelo método acima, o critério adotado é de que a sua taxa interna de retorno seja igual ou superior ao custo de oportunidade do capital para a empresa.

Na área de producăo animal, pesquisas sobre a viabilidade econônica săo raros, podendo-se citar o de sá (1985) que analisou a viabilidade, sob condicóes de risco, de projetos de investimentos para a engorda de bovinos de corte, em confinamento, no Estado de Goiás. Na avaliacão econômica utilizou o critério da taxa interna de retorno (TIF). A análise revelou taxas variadas, segundo as condicóes especificas de cada projeto, e que, quando comparadas às respectivas alternativas do custo do capital para a empresa, indicou que os projetos eram economicamente viáveis.

Anteriormente, em 1972, IIIAS avaliou a politica econômica para a pecuária de corte no Brasil, encontrando taxas internas de retorno, com valores entre $4,2 \%$ e $35 \%$.

VIEIF'A (1975) estudando inovacŏes tecnológicas na pecuária de corte no Estado de Săo faulo, constatou TIf variando entre $18,22 \%$ e $23,69 \%$ para as diversas 
alternativas de producăo analisadas.

\section{Razão beneficio/custo:}

A razăo beneficiolcusto consiste na relacăo entre o väior presente dos beneficiose o valor presente dos custos e pode ser representado assim:

$$
\begin{array}{r}
\text { dos custos e pode se } \\
B / C=\frac{\sum_{t=1}^{i N} L_{t}(1+0)-t}{L_{0}}
\end{array}
$$

onde, 0 numerador $=0$ valor descontado dos benefícios adicionais liquidos e $L_{0}=0$ valor presente do investimento Trata-se de um método muito empregado na avaliagăo de projetos governamentais. Segundo HOFFMANW et alii (1976), um projeto só deverá ser implantado se apresentar uma relaqăo B/C maior do que a unidade.

lletalhes pormenorizados dos métodos em questão podem ser obtidos em FAFio (1971), HOFFKANN et alii (1976), NOFINHA (1981), CONTALIOF (1981) E outros autores.

No caso da presente pesquisa, cabe assinalar que para o cálculo das receitas brutas (Eeneficios), Tabelas A5.1 a A5.8 (ANEXO 5), utilizaram-se preqos recebidos pelos suinocultores, representativos dos três últimos anos (outubro de. 1985 a outubro de 1988), em valores de juntro de 1988. f escolita desse periodo deu-se em razăo da instabilidade de prefos na suinocultura, e do fato de que - ciclo de producăo de suinos, abrangido desde o nascimento da matriz até o abate das primeiras crias, leva em torno de 18 meses. Este valor foi de cz\$ 3.11. $3,48 /$ arroba. 


\section{RESULTADOS E DISCUSSǑES}

No presente estudo, foram estimados os custos anualizados de produkăo de suinos em quatro reatöes do Estado de Săo Faulo, utilizando-se dos valores médios de dispêndios anuais, especificos a cada localidade.

Conquanto esse método por sj. só năo oferęa dados suficientes para indicar a viabilidade economica da producăo de sujnos em uma dada regiăo, optou-se também por uma análise econômica dos casos estudados, através do cálculo do valor atual (VA), taxa interna de retorno ( $T I F)$, relacăo beneficio/custo(B/C) e pasback simples (F'BS) e payback econômico (F'BE).

Assim sendo, a análise dos resultados foi dividida em duas partes. A primeira se refere aos custos anualizados e a segunda aos indicadores de rentabilidade.

\subsection{Análise dos custos anualizados}

A partir da planilha dos fluxos de dispêndios monetários a fluxos de producăo anual, para um horizonte de 15 anos, calcularamse os custos anualizados de producăo de suinos, a diferentes taxas de atratividade.

Através da Tabela 2 depreende-se que os menores Lustos, a diferentes taxas de desconto, foram observados na Fegiăo de Bragancä Faulista, que em média săo $r \%$ menores do que os registrados em ourinhose Avaré, $e$ g\% 


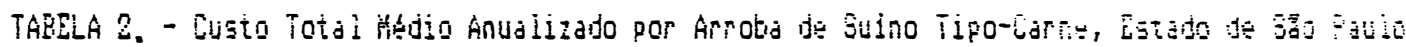

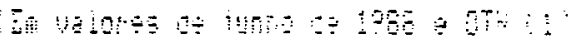

\begin{tabular}{|c|c|c|c|c|c|c|c|c|}
\hline \multirow[b]{3}{*}{ Taxa } & \multicolumn{6}{|c|}{ 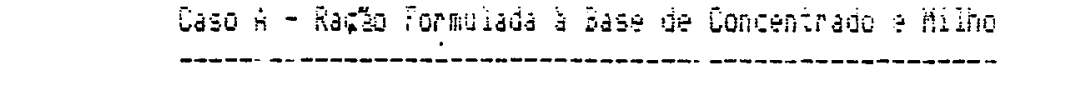 } & \multirow{2}{*}{\multicolumn{2}{|c|}{ hogigu de findacado }} \\
\hline & Regien & fi Gursinios & ar agangis & avista & hoglo be & fivate & & \\
\hline & ZZt/arrocia & OTHiarrobia & Czatarroba & Oihlarrobia & CZ\$/arrous & DThtoriosos & 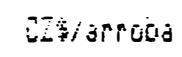 & onitaros \\
\hline $8 \ddot{6}$ & $0.75,0$ & 1,78 & 8.907 .98 & 1,30 & $2.58,7$ & 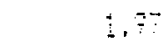 & $2,60 \div .4$ & \\
\hline $10 \%$ & $2.703,00$ & 2,06 & $2.521,80$ & 1,89 & $0,711,7+$ & 5,8 & $8.730,9$ & \\
\hline $12 \%$ & $8.770,69$ & 2,07 & $2,502,4 \bar{i}$ & 1.90 & $5.775,84$ & 2.6 & 8.796 .97 & \\
\hline $1 \%$ & $5,90, \div$ & 3,15 & $8,87,3$ & 8,3 & $2.33,5$ & $\therefore \therefore$ & $8.90, \div$ & $\therefore$ \\
\hline $20 \%$ & $3.062,11$ & 2,2 & $2,343,62$ & 2,13 & $3.077,07$ & 2,8 & $3.079,90$ & 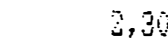 \\
\hline
\end{tabular}

\begin{tabular}{|c|c|c|c|c|c|c|c|c|}
\hline \multirow{3}{*}{ 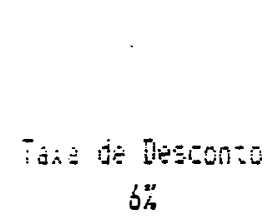 } & \multicolumn{2}{|c|}{ Fegiono de un intos } & \multicolumn{2}{|c|}{ 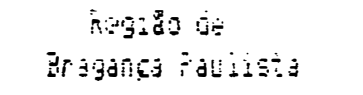 } & \multicolumn{2}{|c|}{ TOjisu de Auart } & \multicolumn{2}{|c|}{ 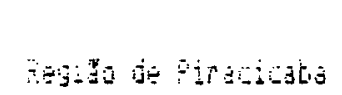 } \\
\hline & Eztizroba & Whitariots & Utartas & Oifiotrobo: & 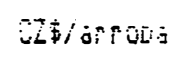 & Thideresos & $20+3+30$ & OHatione \\
\hline & $2,401,7 i$ & 1,80 & $2,347,96$ & 1,60 & $3.410,4=$ & 2.25 & $3,437,04$ & 1,20 \\
\hline $1 \hat{V}_{h}^{\prime \prime}$ & $3,527,64$ & $\therefore, 89$ & $2.360,93$ & 1,70 & $2,537,65$ & 1,90 & $2,558,7$ & 1,7 \\
\hline $12 \%$ & 5.594 .65 & 1,74 & $2,400,69$ & 1,8 & $5,60 \div, 7$ & 1,94 & $5.63,15$ & $t, p$ \\
\hline $15 \%$ & $\therefore, 600,70$ & 205 & $8,814,64$ & 1,80 & $2.761,95$ & 2,0 & $5.723,7 \mathrm{~s}$ & $2,0 \div$ \\
\hline $20 \%$ & $3.901,74$ & 8,8 & $2,677,96$ & 2,0 & $3,5 i 1,83$ & 2,2 & $2,900,5$ & $\therefore:-$ \\
\hline
\end{tabular}

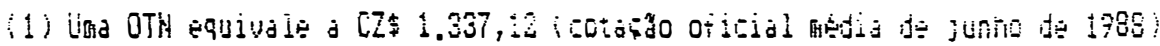
Fon ex: liados da Fusquisa 
inferiores aos constatados em Firacicaba.

A explicacăo para essa vantagem obtida por Braganca Faulista está no fato de que a despejto de se ter ai encontrado indices técnicos ( $n$ de partosiporca, ne de: leitöes nascidos vivos por parto, ete.) semelhantes às outras regiöes, registrou-se uma produtividade, medida em termos de arroina produzida de carne por matriz instalada, relativamente maior que as demais.

Sadlenta-se também as diferenazs verificadas entre os dois casos estudados, ou seja, caso A - com os animais alimentados a base de raçăo formulada à partir de concentrado e milho e caso $\mathrm{B}$ - em que se usa racăo de custo mínimo formulada à partir de pirémix vitaminico mineral. Em todas as localidades estudadas esse ultimo caso mostrou custo inferior, comparativamente ao caso A (Tabela 2).

Lleve-se ressalvar, entretanto, que no item gasto com racóes só foram considerados os custos de aquisicăo dos alimentos, năo se computando os dispêndioss adicionais com măo de obra especializada, assistência técnica, etc, que normalmente incidem nas racöes preparadas ao nivel de granja.

Sobre este aspecto, as informacöes disponiveis na pesquisa efetuada de caracterizacăo das unidades produtoras de suínos nas regiöes de Ourinhos, Braganga Faulista, Firacicaba e Avaré (AWEXO 2) indicam a tendência da substituigăo da raç̃o comercial pela racăo de fabricacăo própria pelos produtores, fato já constatado, em termos gerais, por MAFiTINS ( 1987 ). 
Essa mesma autora enfatiza que os suinocultores

premidos pelas suas margens negativas vêm tentando reduzir custos, iustamente pelo lado das racóses que constituem a sua maior despesa.

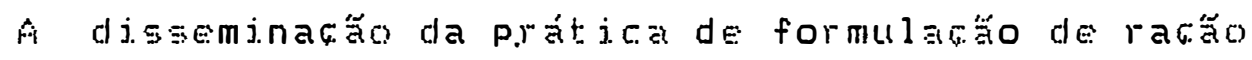
ao nivel de granja, fato que ocorreu depois de 1975, deu-se após o surgimento das industrias de super concentrados de minerais $e$ vitaminas $e$ da maior disponibilidade de equipamentos modulares (trituradores, misturadores, etc:). Também os programas de formulatăo tornaram-se mais acessiveis, seja através de representantes de fabricantes de prémix ou de empresas de consultoria na área (MAFITINS, 1987 e Consumo de racöes balanceadas, 1988 ).

Outra alternativa encontrada pelos suinocultores sEgundo SANTIAGO (1982) E MOURA (1985) têm sido o uso, em maior frequência, de matérias primas alternativas mais baratas para compor as racótes, principalmente residuos da agroindustria (soro, melaco, residuos das industrias de tomate, ervilha, milho, palmito, etc.).

No entanto, conforme MOUfiA (1985), năo existe à disposicăo do suínocultor uma tecnologia adequada para utilizacăo da maioria das fontes alternativas de energia $E$ proteina.

Ainda, com relacăo às racões, é importante: frisar que embora os modernos métodos de formulatăo, como é o caso da programacăo linear, tenham se mostrado adequados para atender às exigências da atual suinocultura industrial, estes nắo levam em consideracăo fatores 
relevantes

como

a

palatabilidade

e textura

dos

ingredientes ou a presenea de princjpios com abáo deletérica (FEFES \& MAFiQUES, 1988).

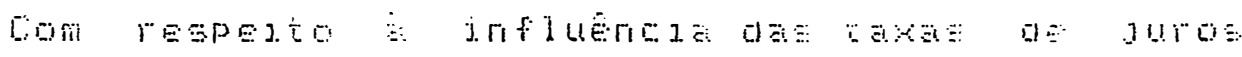
sobre os custos, observou-se que existe relacăo direta entre estes dois indicadores, o que implica que quanto maior é a taxa, maior o custo por arroba. É preciso lembrar que esta taxa representa para o investidor, a taxa minima de atratividade para o empreendimento, correspondendo ao custo de oportunidade do capital.

\subsection{Análise dos indicadores de rentabilidade}

A Tabela 3 mostra os indicadores de rentabilidade obtidos tomando $10 \%$ como taxa de desconto. Verificou-se para as regiŏes estudadas que o caso B (racăo formulada de custo mínimo, à partir de prémix vitaminico-mineral) apresenta indicadores com melhor atratividade que o caso A cracto formulada à base de concentrado $E$ milhos.

Valor atual:

Fiara o horizonte considerado de 15 anos $e$ a valores de junho/88, os valores atualizados (VA) foram todos positivos. Em termos médios os valores encontrados para o caso E (racăo formulada de custo minimo) săo $38 \%$ 


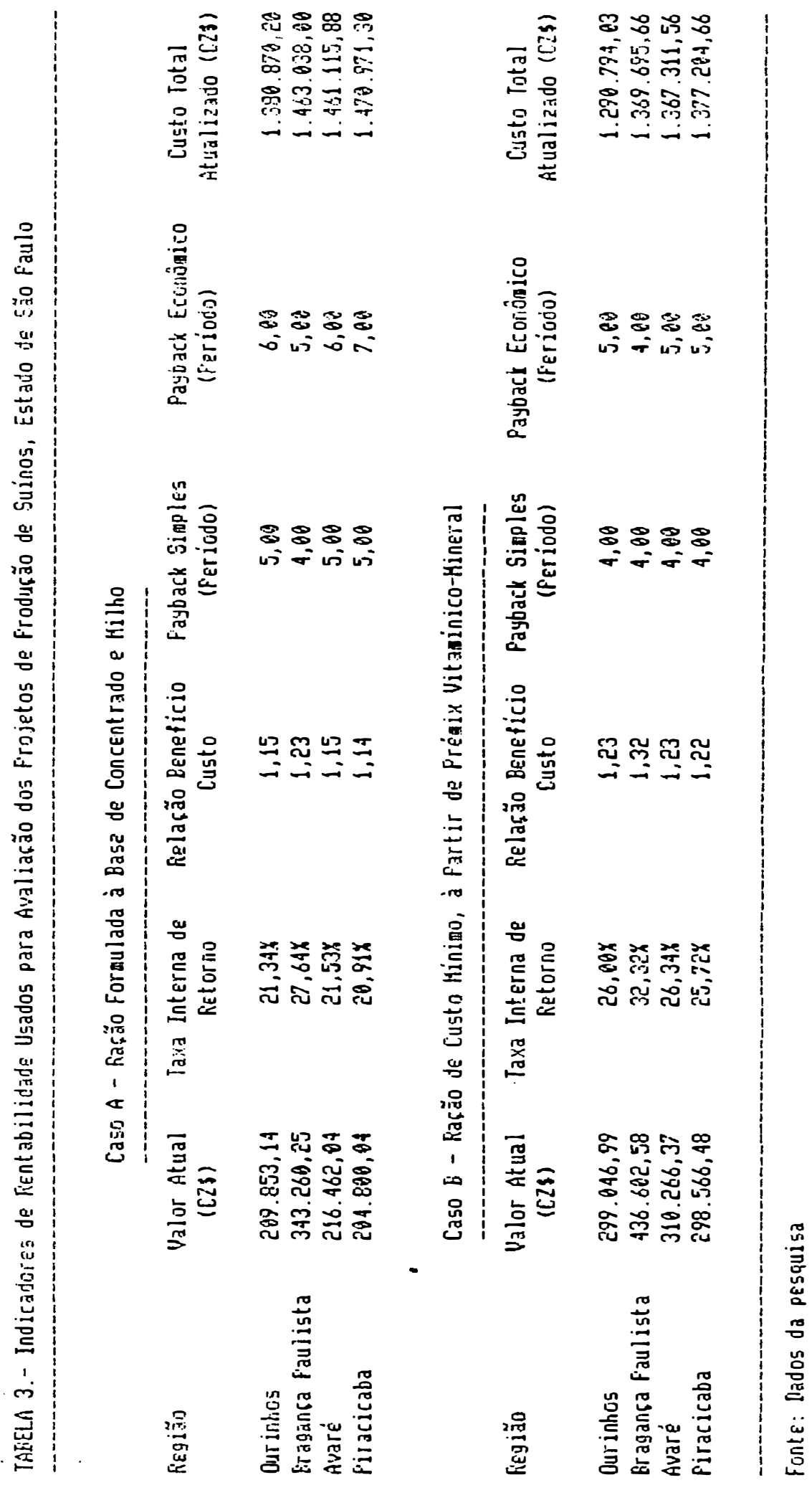


majores que os da alternativa $A$. Esses valores posjtjvos estariam indicando que esses projetos calculados com base no custo do capital para empresa săo maiores que o valores dos investimentos iniciais.

A fim de mostrar o efejto da variacăo nos fatores de desconto sobre o valor presente( $b$ ), consjderaram-se taxas variando de 0 a $50 \%$ (Figura 1. ). Fode-se depreender que quanto maior o custo do capital, menos atrativo torna-se um mesmo projeto. o valor atualizado decresce monotonicamente com relagăo aos aumentos na taxa de desconto (NOFiONHA, 1981.).

0 valor atualizado mais elevado foi encontrado para o sistema de producăo desenvolvido em Braganca Faulista (caso B), enquanto que o menor foi obtido para o sistema de producăo que usa racăo formulada à base de concentrado e milho na regiăo de Firacicaba(casoA).

Reląão beneficiolcusto:

Tendo em vista que os valores atualizados encontrados foram positivos, a relacăo beneficio/custo foi para todos os casos esiudados superior a um. Ilo ponto de vista econômico qual quer um dos sistemas de producăo seria viável. A major relacăo benefjcio/custo foi encontrada

(6) Escolheu-se como exemplo o projeto elaborado para a regiăo de Firacicaba, caso A. 


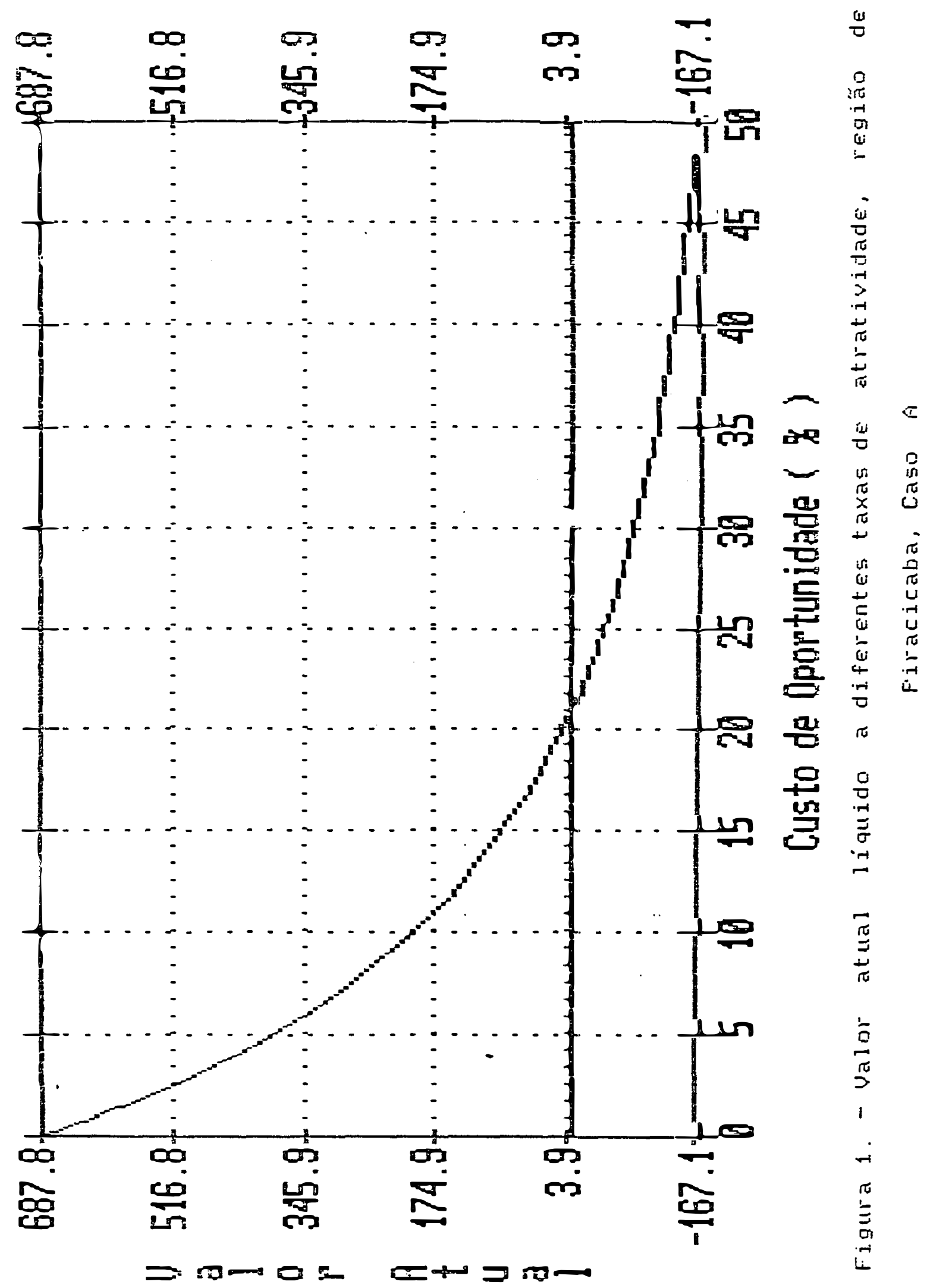


para o sjstema de producăo baseado na racăo formulada partir de premix vitaminico-mineral para a reg̣ăo de Braganca Faulista $(E / C=1,32)$.

\section{Payback simples:}

- payback simples revelou um periodo minimo de 4 até 5 anos para recuperacăo do capital investido, dependendo do sistema de producăo. Fara o caso B (racăo formulada de custo mínimol foi de 4 anos. Já no caso $A$ (racăo formulada à base de concentrado e milho) esse tempo se estendeu até 5 anos (Tabela 3 ).

\section{Payback econômico:}

o payback econômico que leva em consjderacăo o valor do dinhej.ro no tempo, à taxa de $10 \%$ a. a., ampliou o prazo de recuperacão do capital para até 7 anos (Tabela 3). Enquanto o payback económico para o caso E variou de A (regiăo de Braganca Faulista) a 5 anos (Avaré, Ourinhos e firacicabal. Fara o caso A a variacăo foi de 5 (regiăo de Braganca Faulista) até 7 anos(regiăo de Filacicaba).

$$
\text { Vale dizer que a equivalência entre o payback }
$$

simples e econômico (4 anos) observada na regiăo de Braganca Faulista deveu-se ao fato do programa utilizado no cálculo desses indicadores só dar como resultados 
números inteiros.

Taxa interna de retorno:

Os resultados relativos às taxas intẹnas de retorno variaram de $20,91 \%$ a $27,64 \%$ nos projetos do caso A E de $26,34 \%$ a $32,32 \%$ nos projetos do caso E.

Conceitualmente a TIR representa exatamente a taxa de juros sobre o saldo do capital implantado no projeto, durante sua vida litil, enquanto o capital inicial está sendo recuperado (NOFONHA, 1981).

Aqui se encontra um dos grandes problemas na avaliacăo de investimentos, usando-se a TIR, uma vez que se faz necessário a determinacăo da taxa mínima de atratividade ou custo real do capital para cada empresa. A comparacăo dessa taxa minima com a tifi calculada é que permite concluir-se sobre a viabilidade ou não dos Projetos.

Supondo-se que só seja utjlizado capital próprio, a quantificacăo do custo real deste depende das condicáes vigentes na economia em cada periodo, sendo de certa forma explicitado de forma arbitriria (SÁ, 1985).

Consulta à literatura, também, mostra que săo raros os estudos que procuram estimar a taxa de retorno ao capital do setor agricola, tratando-se na maioria das vezes de pesquisas setoriais (NOGUEIFA, 1986). Como também mencionado no trabalho de $S^{\prime}$ (1985), na impossibilidade de determinála com certeza, 
consideraram-se no presente estudo diversas taxas, variando de 6 a $20 \%$ ao ano.

Assim, na presente pesquisa, supondo-se: a taxa máxima de $20 \%$ a.a., todos os projetos analisados apresentaram-se economicamente viáveis.

Constam também da Tabela 3 os custos totais atualizados para as quatro regiöes $e$ tem-se que em terinos médios os custos relativos aos casos de racáo de custo minimo foram $7 \%$ inferiores àqueles em que se usam de racăo formulada à partir de concentrado e milho.

Têm-se a salientar que ourjinhos apresentou custos totais inferiores às demais regiöes, no entanto, dada a sua menor produtividade, alguns de seus indicadores de rentabilidade foram relativamente menos atrativos do que os obtidos para Braganca faulista $e$ Avaré. Isso deve-se à dependência essencial dos métodos em questäo aos fluxos de caj.xa dos projetos.

\section{CONCLUSÕES}

A despeito das limitacóes existentes neste trabalho no que tange às dificuldades em se determinar com exatidăo os investimentos ocorridos em benfeitorias, à inexistência de contabilidade sobre transacótes na suinocultura, o que dificulta a quantificacăo dos insumos utilizados $e$ também à estimativa de outros itens de dispêndios, espera-se que os resultados encontrados possam - servir de orientacão năo só para os suinocultores que 
estejam em atividade como para futuros investimentos, que ventram a ocorrer na suinocultura. fio mesmo tempo pretende-se com este estudo levantar problemas para a execucăo de pesquisas no futuro, năo só no campo econômico como técnico.

Conforme os objetivos propostos determinaram-se, os custos totais médios da producăo de suinos, ao longo de 15 anos, referentes a quatro regiöes do Estado de sä́ Faulo. Fiara os sistemas de producăo estudados os que usavam racăo formulada de custo minimo, à partir de prémix vitaminico-mineral mostraram-se mais vantajosos e com menores custos que os sistemas que utilizaram rafăo formulada à base de concentrado e milho.

A análise econômica da atividade mostrou diferentes indices de rentabilidade ao nivel regional, e para os dois casos estudados de arracoamento. Os resultados indicam que a suinocultura é economicamente viável, desde que observadas as condicóes assumidas no presente estudo.

Ilestaque-se a influência da alimentą̆äo nos dispêndios dos suinocultores, indicando a necessidade de se encontrar formas alternativas, como se pode observar ao comparar-se os resultados encontrados tanto nos custos anuaiizados, quanto na análise de rentabilidade, usando-se de racăo feita de concentrado de milho e racăo de custo minimo. Fara todas as regiöes observou-se a superiorjdade das estimativas desse ulitimo caso. 
Assim, recomenda-se um trabalho conjunto entre a pesquisa extensáo rural a fim de que sejam avaliado: o valor nutritivo das alternativas alimentares existentes e desenvolvidos programas de formulacăo de racóes aproveitando os subprodutos existentes em cada regiäo do Estado.

Tratando-se a suinocultura uma atividade que tem convivido com graves crises decorrentes de precos năo remuneradores, fazem-se necessairias pesquisas que indiquem a viabilidade econômica desse setor sob condicóes de incerteza. 
REFERENCIA B́IBLIOGRÄFICA

ACEIN-SIPA. Evolução do abate de suínos sob inspeção Federal do SIPA: Brasilia, s.d. (Quadro)

ANILISE econônica sobre a situação da suinocultura. A Lavoura, RJ, 88: 13, jan./fev. 1986 .

ARAUJo, P.F.C., coord. Progranas de investimento na agricultu ra paulista. São Paulo, Banco de Desenvolvimento do Estado de São Paulo, 1979 . 80 p.

ARRUDA, S.T. Anälise econômica da produção da borracha natural. no Estado de São Paulo. São Paulo, Secretaria de Agricultura e Abastecimento, IEA, 1987. 129p. (Relatório de Pesquisa, $17 / 87$ )

ARRUDA, Z.J. Estimativa de custos de formacão e conservacão de. pastagens para a região Centro-0este do Brasil. Brasília, EMBRAPA-DID, 1982. 42p. (Circular Técnico, 8)

BARROS, H. Os métodos de cälculo dos custos de produção aplica da à viticultura. $\quad$ Revista Agronômica, Lisboa, 48, 1965.

BRANDT, S.A.; MARTINS, M.I.G.; MORO, S.; WONG, S.; ALMEIDA, J.M. C. Ciclos e integração no mercado de carnes. R. ECON. Rural, Brasilia, 25(3): 303-309, jul./set. 1987 . 


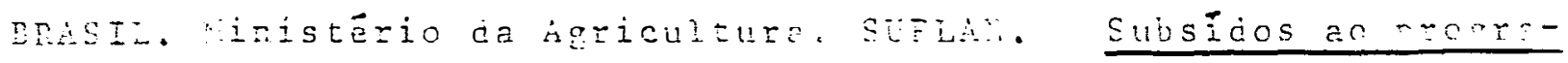
ma de apoio ao desenvolvimento da suinocultura. Brasilia, 1976. S.P.

CAMARGO, A.M.M.P. Substituição regional entre as principais atividades agrícolas, no Estado de São Paulo. Piracicaba, ESALQ/IISP, 1.983. 236P. (Dissertação de Mestrado)

CANTOS, C. Panorama da suinocultura nas regioões sul e sudeste. Informacões Econômicas, SP, $\underline{9}(1): 19-24$, nov. 1977.

CENSO AGROPECUARIo, 1920-80. Rio de Janeiro, Fundação IBGE, 1920-84.

0 CONSUMO de rações balanceadas. O Estado de são Paulo, São Paulo, 31 maio 1989. Suplemento Agricola, 34(1755): 13-16.

CONTADOR, C.R. Avaliação social de projetos. São Paulo, Atlas, 1981 . $301 \mathrm{p}$.

CORREA, C. 0. Custo total de produção: suinocultura. Marilia, CATI/DIRA, $1986.6 \mathrm{p}$.

COSTA, N.; TURRA, F.E.; SILVEIRA, G.B.; MACHADO FILHO, G.P. C.USto de producão, bovinos, suínos, aves. Curitiba, organizacão das Cooperativas do Estado do Paranä, 1985. 90 . 
DIAS, G.L. da S. Ávaliação da politica econômica para é Decu $\vec{z}-$ ria de corte no Brasil. São Paulo, FEA/USP, 1972. 118p. (Tese de Doutorado)

EMBRAPA. Centro Nacional de Pesquisa de Suínos e Aves. Caracteristicas da produção de suínos no Estado de Santa Catarina. Concórdia, 1979 . 25 .

EMBRAPA. DID. Programa nacional de pesquisa de suinos. Brasi 1ia, 1981. P. 33-34

EMBRATER. Sistemas de produção para suinos, ES. Vitōria, 1980. 27P.. revis. (Semi Sistemas de Produção, Boletim, 191)

FAO PRODUCTION YEARBOOK. Roma, diversos anos.

FARO, C. Critērios. quantitativos para avaliação e seleção de. projetos de investimentos. Rio de Janeiro, IPEA/INPES, 1971 . 142p. (Monografias, 2)

GASPAR, A. Sistemas de criação de suínos. Campinas, Secretaria da Agricultura. CATI, s.d. $4 \mathrm{p}$.

GASTAL, E.F. \& ARAUJO, M.O.C. Estudo de administração rural em Ibiruba.. Porto Alegre, ASCAR, 1965. p. 18,40-1. (Progra ma Cooperativo de Extensão Rural) 
GODINHO, J.F. Suinocultura: tecnologia e viabilidade económica. 3.ed. São Paulo, Nobel, 1981 . $323 \mathrm{p}$.

GOMES, A.T. Anālise dos custos de producão de süinos em um grupo de explorações localizadas em micro-regiões coloniais - RS, 1973. Porto Alegre, Universidade Federal do Rio Grande do Sul, IEPE, 1976. 66p. (Tese - Mestre)

HOFFMANN, R.; EXYGLER, J.J.C.; SERRANO, O.; THAML, A.C.M.; NEVES, E.M. Administracão da empresa agrícola. São Paulo, Pioneira, 1976 . $323 p$.

MARTINS, S. Fluxos de transformacão da producão vegetal e prodüção animal. São Paulo, Secretaria da Agricultura, IEA, 1987. 25p. (Relatório de Pesquisa, 33/87)

MACHADO, L.C.P. Os suinos. Porto Alegre, A Granja Ltda, 1967. $622 \mathrm{p}$.

MOURA, M.P., coord. Programa integrado de pesquisa: suínos. São Paulo, Secretaria de Agricultura e Abastecimento. CPA, 1985. P. 5-8

MYADA, V.S. \& LAVORENTI, A. Atualização em suinocultura. Piracicaba, FEAL?, 1985. F.7

NEVES, E.M. Anälise econömica do investimento em condição de riscona cultura da borracha. Piracicaba, ESALO/USP, 1984. 171p. (Tese de Livre-Docência) 
NEVES, E.M. Custos agrícolas: cana de açūcar para produção de älcool. In: SEMINARIO SOBRE TECNOLOGIA E ECONOMIA DO ALCOOL, 1, São Paulo, 1980. Anais. São Paulo, Secretaria da Indúsrria, Comērcio, Ciência e Tecnologia, 1980. p.139-144.

NEVES, E.M. \& SHIROTA, R. Consideração sobre a importância, determinação e atualização dos custos agricolas. Piracicaba, FEALQ/DESR/ESALQ, 1987 . 26P.

NEVES, E.M.; SARTORELLI, S.R.P.; SHIROTA, R. Custo de producão. da laranja no Estado de São Paulo. Piracicaba, EsALQ/FEALQ, 1988. 24p. (Relatório de Pesquisa)

NEVES, E.M.; SHIROTA, R.; SARTORELLI, S.R.P. Anälise de inves timento na agricultura: uma metodologia para determinação de custo para culturas perenes. In: CONGRESSO LATINO-IBERO-AME RICANO DE PESQUISA OPERACIONAL E ENGENHARIA DE SISTEMAS, 4 , Rio de Janeiro, 1988. p.87-88. (resumo)

NOGUEIRA, E.A. Estudo sobre a viabilidade economica-financeira de cacauicultura no Estado de São Paulo. São Paulo, FGV. Escola de Administração de Empresas de São Paulo, 1986. 133 . (Tese de Mestraio)

NORONHA, J.F. Projetos agropecuärios: administração financeira, orçamentação e avaliação econômica. Piracicaba, FEALo, 1981. $274 \mathrm{p}$. 
OLIVEIRA, J.G. \& KONZEN, O.G. Relações receita-custos na suinocultura do Rio Grande do Sul: 1970-1978. R. Econ. Rural, Brasîlia, 19(2): 259-285, abr./jun. 1981.

PAUL, J.M., coord. Diagnóstico da suinocultura nacional. Florianópolis, CEPA/SC, 1977. $229 \mathrm{p}$.

PERES, F.C. \& MAROUES, P.Y. Manual de cálculo de racõos de custo minimo. Piracicaba, ESALO/FEALQ, 1988 . p.5.

PINHEIRO, A.C.; PROTAS, J.F. da S. IRANG, R. A funçaõ de produção e a relação de preços insumo - produto, como determinantes do peso ótimo de abate de suínos. R. Econ. Rural, Brasilia, 21 (3): 371-379, jul./set. 1983 .

PORTAS, A.A. Suinocultura em São Paulo. Casa da Agricultura, Campinas, 6 $(4): 18-23$, jul./ago. 1984 .

PROGNOSTICO, 78/79 - 86/87. São Paulo, Secretaria da Agricultura, IEA, 1978-1986.

PROTAS, J.F. Custo médio de prcducão de suínos para abate. Concórdia, EMBRAPA - CNPSA, 1980.

PROTAS, J.F. \& TALAMINI, D.J.D. Resultados técnicos e económicos de propriedades suinicolas com diferentes tamanhos de rebanhos em Santa Catarina. R. Econ. Rural, Brasilia, 20(4): 575-586, out./dez. 1982 . 
PROTAS, J.F.; LAYZER, E.A.; PINHEIRO, A.C.A. A alocacão de recur sos eru pequenas propriedacies de Santa Cacarina: uma anäise de sensibilidade. R. Econ. Rural, Brasilia, 24 (2): 161-178, abr./ jun. 1986 .

REGAZZINI, P.S. Projeto técnico de suinocultura confinada. Pi tangueiras, Humus Agrícolas S/A, 1977. 50p. mimeo.

ROPPA, L. Alternativas alimentares para a diminuição do custo de produção. Anuärio Suinicola, SP, :42-50, dez./jan., 1984/85.

ROPPA, L. Produção de suínos no Brasil. Suinocultura Industrial, SP, $\underline{9}(112): 8-30$, ago. 1988 .

SA, J.M. Anälise econômica da engorda de bovinos em confinamento, trado)

SAnTIAgO, M.M.D. Suinocultura. Prognóstico, 82/83, SP, 11:204207,1982 .

SÃo PAULO. Secretaria da Agricultura. Comissão de Programação de Suinos. Plano indicativo da suinocultura. São Paulo, 1976 . p. 13-28.

SELBACH, J.C. A suinocultura a nível de emoresa: Ibirubä/RS, 1967. Porto Alegre, Universidade Federal do Rio Grande do Sul. IEPE, 1971. 120p. (Tese de Conclusão dos Cursos de Pós-Graduação em Economia Rural e Sociologia Rural, 13) 


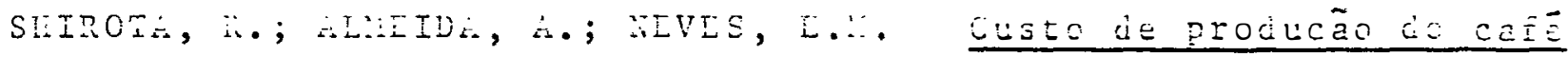
nas divisões regionais agrícolas de Ribeirão Preto e são José do Rio Preto. Piracicaba, ESALQ/USP, 1988. 40p. (Reiatório de Pesquisa)

SINOPSE PRELIMINAR DO CENSO AGROPECUARIO: Censos econômicos, 1985 Bräsil, Região Centro-oeste, Sul, Noroeste e Sudeste, Rio de Ja neiro, $\underline{4}(2-6) 1987$.

SítTESL ANUAL DA AGRICULTURA DE SANTA CATARINA. Florianónolis, Instituto CEPA-SC, $1982-88$.

SITUAC̆̃o econômica do mercado de carnes. Suma Agrícola,RJ, (11): 19-24, nov. 1988 .

SOUZA, A.T.V.; TELLES, E.G.; CARNEIRO, J.M.; VASCONCELOS, M.; FREIRE, J.A.; OLIVEIRA, S.G. Fontes alternativas de proteínas de origem animal: suinocultura. Belo Horizonte, Secreta ria de Estado da Agricultura, APC/CEPA, 1979. 46p. (APC/ CEPA/ $021 / 12 / 79$ )

SUINOCULTURA: a saída poderia ser o mercado internacional. groanalysis, RJ, 6 (3): 42-46, mar. 1982 .

TROCOLLI, I.R. \& WEDEKIN, I. O Brasil e o mercado mundial de carne. Agroanalysis, $R J, \underline{5}(7):$ 3-19, jul. 1981 . 
VIEIRA, C.A. Análise econômica de engorda de bovinos de corte. Agricultura em São Paulo, SP, 22(1/2): 51-90, 1975 .

ZIRLIS, A.E.F. Mercado de produtos: suinocultura. Prognóstico Agricola, 88/89, SP, 1: 5-96/5-100, 1988 . 
ANEXO 1. ASPECTOS DA

SUINOCULTURA NO MUNDO, BRASIL E ESTADO DE SÃO PAULO 


\section{A suinocultura no mundo}

A suinocultura é uma das atividades criatórias mais difundidas no mundo, adaptando-se as variadas condicöes de meio ambiente e tecnologia(FAL, 1977).

lientre os paises detentores dos maiores rebanhos destacam-se a China, Estados Unidas da América, Fílssia E Brasil (Tabela A1.1). Estes quatro paises detêm mais de $60 \%$ do efetivo suino do mundo.

Analisando-se as taxas anuais de crescimento do rebanho no periodo 1973-86, observa-se que os maiores acréscimos ocorreram na Holanda (5, $1.1 \%$ ); Fiomênia (3, $55 \%$ ), Espanha $(4,54 \%)$; Canadá $(3,10 \%)$; Japăo $(2,79 \%)$; China $(2,46 \%) ; \quad$ Iugoslávia $(1,51 \%)$. Ilecréscimos foram observados nos Estados Unidos da América $(-0,88 \%)$, Folónia $(-0,22 \%)$, Brasil $(-0,56 \%)$, Feino Unido $(-0,88 \%)$, Filipinas $(-1,21 \%)$ e Vietnă $(-0,83)$, enquanto nos demais paises o: acréscimos variaram entre $0,56 \%$ a $1,43 \%$. Ao nivel mundial, o aumento médio foi de $0,86 \%$.

Apesar da superioridade do Erasil, em termos de: efetivo mundial de suínos, observa-se uma mudanga nessa importância quando se analisam dados de producăo de carne 
TABELA A1.1. - Euoluç̧o do Rebantio Sufno, Fir incipais Falses: 1973 - 88

(E- 1000 Catecas)

(continua)

\begin{tabular}{|c|c|c|c|c|c|c|c|c|}
\hline Pais & 1973 & 1974 & 1975 & 1976 & 1977 & 1978 & 1979 & 1980 \\
\hline China & 235.831 & 233.638 & 232.809 & 278.315 & 283.676 & 295.540 & 305.607 & 325.123 \\
\hline U.R.S.S. & 66.593 & 70.032 & 72.273 & 57.899 & 63.055 & 70.511 & 73.484 & 73.898 \\
\hline E.E.U.U. & 59.180 & 61.106 & 54.693 & 49.267 & 54.934 & 56.539 & 60.356 & 67.353 \\
\hline Brasil & 33.000 & 34.000 & $34.19 n$ & 35.205 & 36.800 & $37: 500$ & 35.695 & 34.183 \\
\hline Alesiantia Ocidental & 20.028 & 20.452 & 20.234 & 19.805 & 20.589 & 21.386 & 22.641 & 22.374 \\
\hline Polonia & 19.782 & 21.496 & 21.311 & 18.848 & 20.051 & 21.717 & 21.224 & 21.326 \\
\hline Espantia & 8.472 & 8.308 & 7.865 & 8.583 & 9.008 & 9.770 & 9.769 & 10.715 \\
\hline Holanda & 6.425 & 6.719 & 7.279 & 7.507 & 8.288 & 9.172 & 9.728 & 10.138 \\
\hline Rowenia & 8.785 & 8.987 & 8.566 & 8.813 & 10.193 & 9.744 & 10.337 & 10.899 \\
\hline Franca & 11.387 & 11.560 & 12.031 & 11.451 & 11.509 & 11.548 & 11.340 & 11.446 \\
\hline Alemantia oriental & 10.361 & 10.849 & 11.519 & 11.501 & 11.891 & 11.757 & 11.734 & $12.13 \%$ \\
\hline Japz̆o & 7.590 & 8.018 & 7.684 & 7,459 & 8.132 & 8.780 & 9,491 & 9.988 \\
\hline Héxico & 10.753 & 10.860 & 11.466 & 11.694 & 11.986 & 12.321 & 12.578 & 13.222 \\
\hline Canada & 6.958 & 6.455 & 5.913 & 5.708 & 6.170 & 6.653 & 8.074 & 9.688 \\
\hline Ilinaglarsa & 8.423 & 7.763 & 7.682 & 7.701 & 7.925 & 8.751 & 9.348 & 9.957 \\
\hline Itália & 7.990 & 8.201 & 8.814 & 8.888 & 9.097 & 9.420 & 9.822 & 8,807 \\
\hline Iugoslávia & 6.342 & 7.401 & 7.683 & 6.536 & 7.315 & 8.452 & $? .747$ & $? .508$ \\
\hline Reino Unido & 8.979 & 8.551 & 7.540 & 7.947 & 7.815 & 7.708 & 7.864 & 7.815 \\
\hline Filipinas & 8.627 & 9.300 & 9.700 & 9.700 & 5.696 & 6.910 & 7.445 & 7.734 \\
\hline Vietng & 7.500 & 11.200 & 8.000 & 9.224 & 9.058 & 8.823 & 9.354 & 10.000 \\
\hline Total hundial & 652.925 & 661.245 & 654.665 & 649.411 & 704.105 & 737.804 & 763.410 & 794,581 \\
\hline
\end{tabular}

(1) Estimativa

(2) Previszo

Fonte: FAO (diversos anos) 
TAEELA A1.1. - Euo Iuszo do Fehantio Suino, Fir incipais Fa15es, $1973-88$

(E. 1000 Catrecas)

(conclusso)

\begin{tabular}{|c|c|c|c|c|c|c|c|c|}
\hline Pais & 1981 & 1982 & 1983 & 1984 & 198.5 & 1986 & $1987(1)$ & $1988(2)$ \\
\hline China & 310.251 & 298.528 & 300.780 & 298.536 & 306.790 & 331.396 & 336.933 & 329.283 \\
\hline U.R.S.S. & 76.671 & 73.302 & 76.671 & 78.722 & 77.914 & 77.772 & 79.400 & 78.000 \\
\hline E.E.U.U. & 64.512 & 58.688 & 54.534 & 56.694 & 54.073 & 52.314 & 51.160 & 55.500 \\
\hline Bris & 32.429 & 33.176 & 33.500 & 30.000 & 30.000 & 30.500 & 31.700 & 32.700 \\
\hline Alerantia astonta! & 92.55 & 30.310 & $n g .47^{\circ}$ & 90.449 & 32.617 & 34.300 & $2 \frac{8}{1} .50$ & 84.97 \\
\hline Polonida & 18,480 & 19.471 & 17.564 & 15.858 & 17.207 & 19.170 & 19.619 & 18.800 \\
\hline Espanhia & 10.692 & 12.023 & 11.682 & 12.124 & 11.800 & 15.782 & 15.782 & 15.661 \\
\hline Holanda & 10.315 & 10.254 & 10.590 & 11.008 & 11.800 & 12.908 & 14.063 & 15.000 \\
\hline Romenia & 11.542 & 12.464 & 12.644 & 14.347 & $14.77 i$ & 14.319 & 14.500 & 14.700 \\
\hline França & 11.629 & 11.421 & 11.709 & 11.251 & 10.975 & 10.956 & 12.002 & 13.572 \\
\hline Alesantia Oriental & 12.871 & 12.869 & 12.107 & 13.058 & 13.191 & 12.946 & 12.840 & 12.800 \\
\hline Japzo & 10.065 & 10.040 & 10.273 & 10.423 & 10.718 & 11.061 & 11.354 & $\$ 1.600$ \\
\hline México & 17.562 & 18.373 & 16.460 & 13.137 & 12.320 & 13.115 & 12.357 & 11.438 \\
\hline Canada & 10.190 & 9.810 & 10.070 & 10.741 & 11.032 & 10.664 & 10.826 & 11.276 \\
\hline 『inamarca & 9.799 & 9.288 & 9.504 & 9.016 & 8.960 & 9.104 & 9.422 & 9.500 \\
\hline Itália & 8.928 & 9.015 & 9.132 & 9.187 & 9.041 & 9.138 & 9.278 & 9.350 \\
\hline Iugos lóvia & 7.867 & 8.431 & 8.370 & 9.337 & 8.673 & 7.821 & 8.459 & $8.80 ?$ \\
\hline Reino Unido & 7.828 & 8.023 & 8.211 & 7.782 & 7.793 & 7.930 & 7.955 & 7.855 \\
\hline Filipinas & 7.758 & 7.795 & 7.980 & 7.613 & 7.304 & 7.275 & 6.950 & 7.000 \\
\hline Vietng & 10.000 & 10.494 & 5.182 & 5.886 & 6.569 & 6.674 & 7.057 & 7.100 \\
\hline Total Hundial & 778.736 & 767.495 & 701.516 & 701.742 & 706.785 & 736,415 & 749.080 & 748.657 \\
\hline
\end{tabular}

(1) Estinativa

(2) Previsazo

Fonte: FAO (diversos anos) 
suina (rabela $A 1.2$ ), onde se destacam: China, Estados Unidos, fiepública Federal Alemă, Japăo, Ilinamarca, Folónia, Holanda, Fiepublica llemocrática Alemä, Itália Eélgicà-Luxemburgo.

As taxas anuais de crescimento da producăo de carne suina no periodo $1973-86$ foram expressivas em paises como Ujetnä $(8,56 \%)$; lugoslávia $(6,56 \%)$; México (5,55\%); Espanha $(5,00 \%)$; Folônia $(4,22 \%)$, China $(4,67 \%)$; Itália $(3,85 \%)$; Japăo $(3,41 \%)$; Canadá $(2,80 \%)$; llinamarca $(2,80 \%)$ E Hungria $(2,34 \%)$.

llentre os pajises selecionados, o Brasil, que ocupa uma posicăo pequena na producăo mundial de carne suina $e$ a Holanda foram os línicos que mostraram decréscimos, respectivos, de $0,11 \%$ e $0,03 \%$. Llestaque-se que a China, Comunidade Comum Européia, Estados Unidos e Físsia detêm juntas $79 \%$ dessa producăo.

A explicacăo para o fato da baixa participacăo do Brasil na producăo de carne, deve-se ao fato do pequeno desfrute do rebanho, que pode ser calculado através do número de animais abatidos (Tabela A1.3).

Como aconteceu com o efetivo, a producăo mundial de carne suina mostrou-se crescente, durante a década de setenta motivada pelo bom desempenho econômico da atividade nesses anos. Já nos anos 80 , observa-se um comportamento oscilante, como reflexo do encarecimento dos custos das racónes, problemas sanitários, etc.

Assim em 1982, após o expressivo volume ofertado de 38,0 mihóos de toneladas em 1981, houve reducăo tanto no efetivo como na oferta de carne suina em muitos paises 
TABELA A1.2. - Evoluz3o da Froduça de Carne Sulna. Frincipais Falsis, 1973 - 89

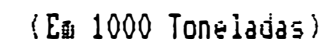

(iconitinua)

\begin{tabular}{|c|c|c|c|c|c|c|c|c|}
\hline País & 1973 & 1974 & 1975 & 1976 & 1977 & 1978 & $197 \overline{9}$ & $1980 \mathrm{j}$ \\
\hline China & 9.488 & 9.702 & 9.800 & 13.327 & 14.377 & 14.566 & 15.580 & 16.438 \\
\hline E.E.U.U. & 5.784 & 6.262 & 5.218 & 5.631 & 5.009 & 6.075 & 7.008 & 7.200 \\
\hline Róssia & 5.081 & 65.480 & 5.749 & 4.238 & 4.950 & 5.302 & 5.389 & 5.092 \\
\hline aínantia Ocidental & 2.271 & 2,320 & 2,415 & 2.483 & 8.483 & 2.617 & 2.688 & 3.247 \\
\hline Japzo & 971 & 1.076 & 1.039 & 1.056 & 1.169 & 1.284 & 1.430 & 1.475 \\
\hline Franca & 1.544 & 1.570 & 1.350 & 1.6 .58 & 1.688 & 1.770 & 1.849 & 1.860 \\
\hline Polonia & 812 & 883 & 892 & 936 & 967 & 1.048 & 1.107 & 1.125 \\
\hline Holanda & 1.759 & 1.885 & 1.812 & 1.540 & 1.542 & 1.785 & 1.792 & 1.711 \\
\hline Alepantia Oriental & 970 & 1.041 & 1.132 & 1.099 & 1.094 & 1.119 & 1.143 & 1.212 \\
\hline Itália & 689 & 738 & 787 & 816 & 904 & 967 & 1.033 & 1.085 \\
\hline llina角arca & 774 & 744 & 734 & 716 & 744 & 812 & 899 & 972 \\
\hline Espantia & 589 & 710 & 602 & 649 & 735 & 803 & 939 & $98:$ \\
\hline Reino Unido & 980 & 978 & 816 & 852 & 905 & 878 & 939 & 928 \\
\hline Hungria & 696 & 810 & 843 & 765 & 865 & 853 & 885 & 905 \\
\hline Canadá & 617 & 611 & 521 & 533 & 539 & 620 & 750 & 877 \\
\hline Dexico & 427 & 414 & 386 & 389 & 410 & 425 & 415 & 497 \\
\hline Viẹtng & 275 & 400 & 370 & 420 & 425 & 410 & 43.7 & 415 \\
\hline Romenia & 674 & 749 & 724 & 772 & 778 & 852 & 925 & 977 \\
\hline Tetrecosloudquia & 671 & 675 & 708 & 699 & 751 & 798 & 797 & 819 \\
\hline Iugosláuia & 306 & 393 & 699 & 600 & 679 & 785 & 743 & 723 \\
\hline Éślgita - Luxemiturgo & 588 & 622 & 579 & 575 & 586 & 631 & 657 & 369 \\
\hline $\begin{array}{l}\mathrm{Br} a s i l \\
\mathrm{k}\end{array}$ & 701 & 793 & $7 \in 0$ & 785 & 834 & 850 & 900 & 900 \\
\hline Filipinas & 358 & 372 & 385 & 373 & 337 & 366 & 377 & 408 \\
\hline Total Kundial & 41.019 & 43.067 & 48.491 & 44.922 & 47.999 & 50.060 & 53.259 & 55.910 \\
\hline
\end{tabular}

(1) Estionativa

(2) Ereviszo

Fonte: FAO (diversos anos) 
TABELA A1.2, - Evolug\%̆o da Produzăo de Carne Suina, Frincipais fiaises, 1973 - 88

(E. 1000 Toneladas)

( coneiusao)

\begin{tabular}{|c|c|c|c|c|c|c|c|c|}
\hline Pais & 1981 & 1982 & 1983 & 1984 & 1985 & 1986 & $1987(1)$ & $1988\langle 2)$ \\
\hline China & 12.648 & 13.478 & 13.161 & $14.44 i$ & 16.547 & 17.968 & 16.905 & 18.144 \\
\hline E.E.U.U. & 7.201 & 6.454 & 6.894 & 6.719 & 6.716 & 6.379 & 6.781 & 7,128 \\
\hline Kússia & 5.219 & 5.300 & 5.760 & 5.927 & 5.855 & 5.900 & 5.850 & 5.850 \\
\hline Aleannia Ocidental & 3.182 & 3.150 & 2.725 & 2.734 & 2.753 & 2.872 & 2.845 & 2.840 \\
\hline Jap?o & 1.396 & 1.428 & 1.429 & 1.424 & 1.531 & 1.552 & 1.575 & 11.615 \\
\hline França & 1.907 & 1.807 & 1.624 & 1.625 & 1.607 & 1.520 & 1.565 & 1.600 \\
\hline Polonia & 1.194 & 1.211 & 1.201 & 1.257 & 1.340 & 1.449 & 1.535 & 1.545 \\
\hline Holanda & 1.346 & 1.462 & 1.444 & 1.288 & 1.494 & 1.752 & 1.664 & 1.581 \\
\hline Alearntia Oriental & 1.279 & 1.155 & 1.231 & 1.210 & 1.252 & 1.235 & 1.260 & 1.265 \\
\hline Itália & 1.106 & 1.108 & 1.046 & 1.098 & 1.067 & 1.170 & 1.180 & 1.185 \\
\hline Jinagarca & 993 & 991 & 1.048 & 1.040 & 1.083 & 1.143 & 1.152 & 1.180 \\
\hline Espantia & 1.021 & 1.115 & 1.120 & 1.181 & 1.157 & 1.166 & 1.150 & 1.150 \\
\hline Réino Unido & 925 & 955 & 1.037 & 955 & 995 & 1.022 & 1.037 & 1.050 \\
\hline Hungria & 906 & 947 & 1.094 & 1.168 & 1.060 & 962 & 1.013 & 1.010 \\
\hline Canadá & 840 & 833 & 852 & 863 & 900 & 908 & 940 & 1.000 \\
\hline MExico & 490 & 497 & 1.136 & 942 & 865 & 910 & 909 & 936 \\
\hline Vietn: & 410 & 451 & 539 & 732 & 831 & 868 & 919 & $91 ?$ \\
\hline Riomenia & 1008 & 908 & 821 & 715 & 875 & 840 & 870 & $890^{\circ}$ \\
\hline Tehecoslousquia & 853 & 743 & 827 & 846 & 832 & 859 & 853 & 357 \\
\hline Iugoslávia & 799 & 817 & 772 & 846 & 780 & 750 & 780 & 815 \\
\hline Bélgica - Luxegturgo & 680 & 680 & 707 & 740 & 726 & 745 & 780 & 775 \\
\hline Erasil & 980 & 970 & 950 & 567 & 600 & 800 & 1.100 & 700 \\
\hline Filipinas & 442 & 460 & 452 & 440 & 430 & 478 & 489 & 505 \\
\hline Total Kundial & 51.853 & 52.080 & 50.794 & 51.749 & 54.339 & 56.236 & 55.878 & 57.672 \\
\hline
\end{tabular}

(1) Estionativa

(2) Previszo

Fonte: FAO (diversos anos) 


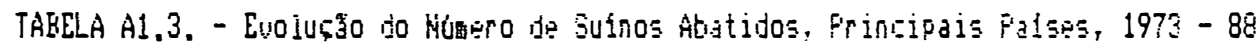

(E⿷ 1000 Cabresas)

(continua)

\begin{tabular}{|c|c|c|c|c|c|c|c|c|}
\hline Pats & 1973 & 1974 & 1975 & 1976 & 1977 & 1978 & 1979 & 1980 \\
\hline China & 168.804 & 173.079 & 175.225 & $238.482^{\circ}$ & 246.197 & 253.205 & 260.428 & 263.956 \\
\hline E.E.U.U. & 77.846 & 83.085 & 69.824 & 74.959 & 78.442 & 78.417 & $90.17^{c}$ & $96.30=$ \\
\hline U.R.S.S. & 63.428 & 65.480 & 76.310 & 57.653 & 62.159 & 67.299 & 67.177 & 68.370 \\
\hline Alesant:a 0 -idental & 30.507 & 31.822 & 32.579 & 32.905 & 34.449 & 36.254 & 37.565 & 37.998 \\
\hline Japzo & 14.023 & 15.370 & 14.384 & 14.279 & 16.075 & 17.448 & 19.226 & 19.943 \\
\hline Franca & 16.575 & 16.740 & 18.458 & 18.675 & 19.283 & 20.108 & 21.071 & 21.109 \\
\hline Holanda & 9.695 & 10.517 & 10.654 & 11.087 & 11.439 & 12.530 & 13.116 & 13.239 \\
\hline Polónia & 20.213 & 21.319 & 20.599 & 17.759 & 16.345 & 30.182 & 19.712 & 19.503 \\
\hline Ilinamarca & 11.424 & 11.041 & 10.894 & 10.539 & 10.999 & 12.012 & 13.410 & $14.57 \Omega$ \\
\hline Reino Unido & 15.128 & 15.324 & 12.841 & 13.364 & 14.194 & 13.787 & 14.781 & 14.630 \\
\hline Canadá & 10.399 & 10.289 & 8.803 & 8.969 & 9.077 & 10.027 & 12.210 & 14.311 \\
\hline Espantia & 7.396 & 9.464 & 8.031 & 8.512 & 9.816 & 10.952 & 12.693 & 13.198 \\
\hline fiotenia & 8.640 & 9.603 & 9.282 & 9.897 & 9.974 & 10.923 & 11.859 & 12.520 \\
\hline Alewantia Oriental & 10.285 & 10.829 & 11.903 & 11.801 & 11.635 & 12.198 & 12.318 & 12.843 \\
\hline Iugoslávia & 10.048 & 11.921 & 12.518 & 11.322 & 12.545 & 14.394 & 13,501 & 13.090 \\
\hline$H \in$ Exico & 6.700 & 6.500 & 5.43 .5 & 5.480 & 5.770 & 5.980 & 5.839 & 7.000 \\
\hline Vietnz & 5.500 & 8.000 & 7.400 & 8.400 & 8.500 & 8.200 & 3.700 & 3.300 \\
\hline Itálja & 7.245 & 7.605 & 8.170 & 8.388 & 9.169 & 9.621 & 10.041 & 10.285 \\
\hline Hungria & 7.499 & 8.787 & 9.283 & 8.431 & 9.210 & 9.254 & 9.639 & $7,88=$ \\
\hline Filipinas & 7.260 & 8.090 & & 3.093 & & & 9.764 & 10.577 \\
\hline Erasil & 10.456 & 10.719 & 11.343 & 11.709 & 12.448 & 12.687 & 18.850 & 14.100 \\
\hline Total Kundial & 603.060 & 627.943 & 624.218 & 701.467 & 702.363 & 737.026 & 773.214 & 796.940 \\
\hline
\end{tabular}

(1) Estigativa

(2) Previszo

Fonte: FAO (diversos anos) 


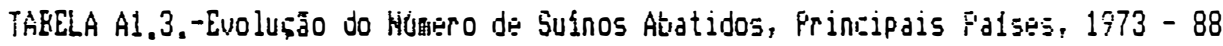
(E⿱一⿴⿻儿口一口阝 1000 Cabieras)

(Con:iusas:

\begin{tabular}{|c|c|c|c|c|c|c|c|c|}
\hline Fals & 1981 & 1982 & 1983 & 1984 & 1955 & 1986 & $1987(1)$ & $1980\left(r_{4}\right)$ \\
\hline China & 201.925 & 207.630 & 206.610 & 220.470 & 239.034 & 256.923 & 248.000 & 252.000 \\
\hline$\Sigma, E, U, U$, & 92.475 & 82.844 & 88,084 & 85.641 & 84.938 & 79.956 & 80.150 & 89.150 \\
\hline U.R.S.S.S. & 68.687 & 69.700 & 72.519 & 73.898 & 71.590 & 71.550 & 71.550 & 7.550 \\
\hline Alérianhia Ucidental & 37.914 & 37.379 & 38.088 & 38.652 & 38.809 & 37.443 & 39.600 & 37.500 \\
\hline Japd̄o & 18.709 & 19.110 & 19.080 & 19.258 & 20.626 & 20.995 & 21.300 & 21,800 \\
\hline Franca & 1.618 & 80.465 & 20.243 & 20.482 & 20.330 & 19.743 & 20.340 & 80.750 \\
\hline Holanda & 14.065 & 14.349 & 14.833 & 15.685 & 16.600 & 17.905 & 19.000 & 19.185 \\
\hline Polonia & 15.874 & 16.398 & 15.049 & 14.051 & 16.037 & 19.151 & 18.834 & 17.500 \\
\hline Eiinamarea & 14.699 & 14.497 & 15.293 & 14.895 & 15.220 & 16.117 & 16.800 & 16.500 \\
\hline Reino Unido & 14.584 & 15.055 & 15.989 & 14.897 & 15.265 & 15.606 & 15.800 & $\$ 5.900$ \\
\hline Canadá & 13.682 & 13.449 & 13.688 & 13.851 & 14.431 & 14.422 & 14.900 & 15.800 \\
\hline Espantia & 14.037 & 15.161 & 14.775 & 15.962 & 15.777 & 15.845 & 15.640 & 1.5 .440 \\
\hline Fiomenia & 12.923 & 11.644 & 13.840 & 12.065 & 15.000 & 14.000 & 14.500 & 14.950 \\
\hline Alemiantia Oriental & 13.879 & 13.419 & 13.440 & 13.929 & 14.268 & 14.000 & 14.100 & 14.200 \\
\hline Iugoslávia & 13.550 & 13.562 & 13.331 & 14.418 & 13.150 & 12.448 & 13.500 & 13.960 \\
\hline$M e x i c 0$ & 6.900 & 7.000 & 16.981 & 13.080 & 12.010 & 12.800 & 12.800 & 13.000 \\
\hline Vietnz & 8.200 & 7.700 & 6.889 & 9.265 & 10.380 & 10.530 & 11.500 & $11,5 \mathrm{G}$ \\
\hline Itália & 10.592 & 10.542 & 10.952 & 11.447 & 11.229 & 11.100 & 11.300 & 12.350 \\
\hline Hungria & 9.927 & 10.117 & 11.334 & 12.664 & 10.568 & 10.295 & 10.03 & 0.500 \\
\hline Filipinas & 10.800 & 11.434 & 9.045 & 8.800 & 8.600 & 8.700 & 8.900 & 7.200 \\
\hline Er asil & 14.000 & $\$ 3.800$ & 13.800 & 8.500 & 8.500 & 10.000 & 11.500 & 3.700 \\
\hline Total Mundial & 730.8 .1 & 726.730 & 702.207 & 711.397 & 732.523 & 751.966 & 751.662 & 76,370 \\
\hline
\end{tabular}

(1) Estimativa

(2) Previsato

Fonte: FAO (diversos anos) 
como: a Folônia, Héxico, Alemantha oriental e

Tchecoslováquia. Entretanto, os reduzidos estoques de animais, no inicio desse ano, nos Estados Unidos, Filissia : Comunidade: Econômica Européia, resultaram em aumentos de: precos, estimulando a producăo nessas localidades, năo só em 1982, como também em 1983 (SÍNTESE ANUAL IIA AGFICULTUFí IIE SANTA CATAFIINA, 1982-88).

As melhorias nas condicóes económicas, dos paises industrializados, ocasionaram en 1983 e 1984 aquecimento do mercado mundial com a consequente expansăo dos rebanhos e producăo, principalmente na comunidade Econômica Européia, China, Japăo e llinamarca. No Kúxico, - aumento da producăo deu-se em fungăo dos programas de incentivo ao consumo interno de carnes (SÍNTESE ANUAL IIA AGFICULTUFiA TIE SANTA CATAFINA, 1982-88).

Até 1985 os custos dos insumos cresceram a niveis superiores aos dos prezos dos suínos. Já em 1986 tanto o milho como a soja atingiram os menores niveis de precos da década ocasionando expansăo na producăo mundial. Llo mesmo modo verj.ficou-se aumento na demanda por carne suina, como resultado do rebaixamento dos estoques mundiais de carne bovina (SÍNTESE ANUAL IIA AGFicULTUFA IIE SANTA CATAFINA, 1982-88).

Fosteriormente em 1987 verificou-se reducăo de 1\% na producăo mundial de carnes, como consequência do aumento nos preqos dos grăos, o que ocasionou abate de: matrizes e queda no ritmo da atividade. Já as estimativa: para 1988, mostravam acréscimos na producăo e comércio de carne suina (ZIFl..IS, 1988). 
Os principais exportadores săo a comunidade Econômica Européda (CEE), China, Alemanha Grientä. Canadá, Hungria, Fiomênia, Estados Unidos da América $E$ Folônia.

\section{A suinocultura no Brasil}

A introducăo dos suinos na América deu-se a partir do século XV. No caso especifico do Brasil os primeiros animais foram trazidos pelos colonizadores portugueses em 1.532 e pertenciam às racas da fienisula Ibérica, existentes em Fortugal. No entanto, a criąăo desses animais ocorreu de modo primitivo, $e$ em muitos casos formaram grupos independentes, junto às matas, os quais deram origem às racas com caracteristicas definidas de pelagem e aspecto exterior (GOIINHO, 1981).

Após o inicio deste século aportaram no Brasil exemplares das racas Berkshire, Tamworth, Large Black $E$ Yorkshire, provenientes da Inglaterra, que já possuia uma zootecnia mais avancada. Continuando os efeitos melhoradores vieram reprodutores foland-China Iluroc-Jersey e, nas décadas de 30 e 40 chegaram espécimes I. Edelschwine, Landschwine, wessex - Saddleback E Hampshile. Na década seguinte (anos 50), Landrace, Large White e Montana (GOIINHO, 1981).

Atualmente as racas de origem estrangeira, majs importantes na suinocultura industrial brasileira, săo a Landrace, Large White, Iluroc, Hampshire e Wessex (GOIINHO, 
1981).

A suinocultura, hoje, caracteriza-se por ser uma das atividades do secor primário de nossa economia mais difundidas e de maior alcance socjal no pais. No entanto, em decorrência de um processo lógico, desenvolveu-se mais junto as zonas de producăo de seus elementos básicos milho e soja e desse modo tanko o rebanho quanto aibate, durante mujtos anos, concentravam-se na regjăo sul e sudeste (BFASIL - Ministério da Agricultura, 1976 $e$ SINTTESE ANUAL IIA AGFICULTUFA IIE SANTA CATAFINA, 1982-1.988) (Tabela A. A).

Contudo, há de se notar que a partj.r da década de 70 ocorreram certas mudancas no quadro acima dada a grande expansăo ocorrida no efetivo de suinos na região nordeste e declinio na regiăo sudeste.

llesse modo, em j.985, a distribuj. ăo desse rebanho, em relacăo ao total do Brasil, era a seguinte: Fiegjăo sul - 38,7\%; Fiegiăo Nordeste - 26,1\%; Fiegjăo Sudeste - $48,2 \%$; Fiegiăo Centro-Deste - $9,8 \%$ e Fiegiăo Norte $-7,2 \%$.

A lideranca da sujnocultura sulina, além do motivo exposto, deve--se ¿̀ grande influencia dos colonizadores $e$ da modernizacăo do parque industrial, melhoria genética do rebanho e implantacăo de modernos sistemas de producăo.

Na regjăo nordeste predomina uma suinocultura de subsistência, cujo destaque decorre do valor quantitativo do rebanho suino. No entanto, a jmplantacăo de projetos, com caracteristicas jndustriais, como vem se processando 


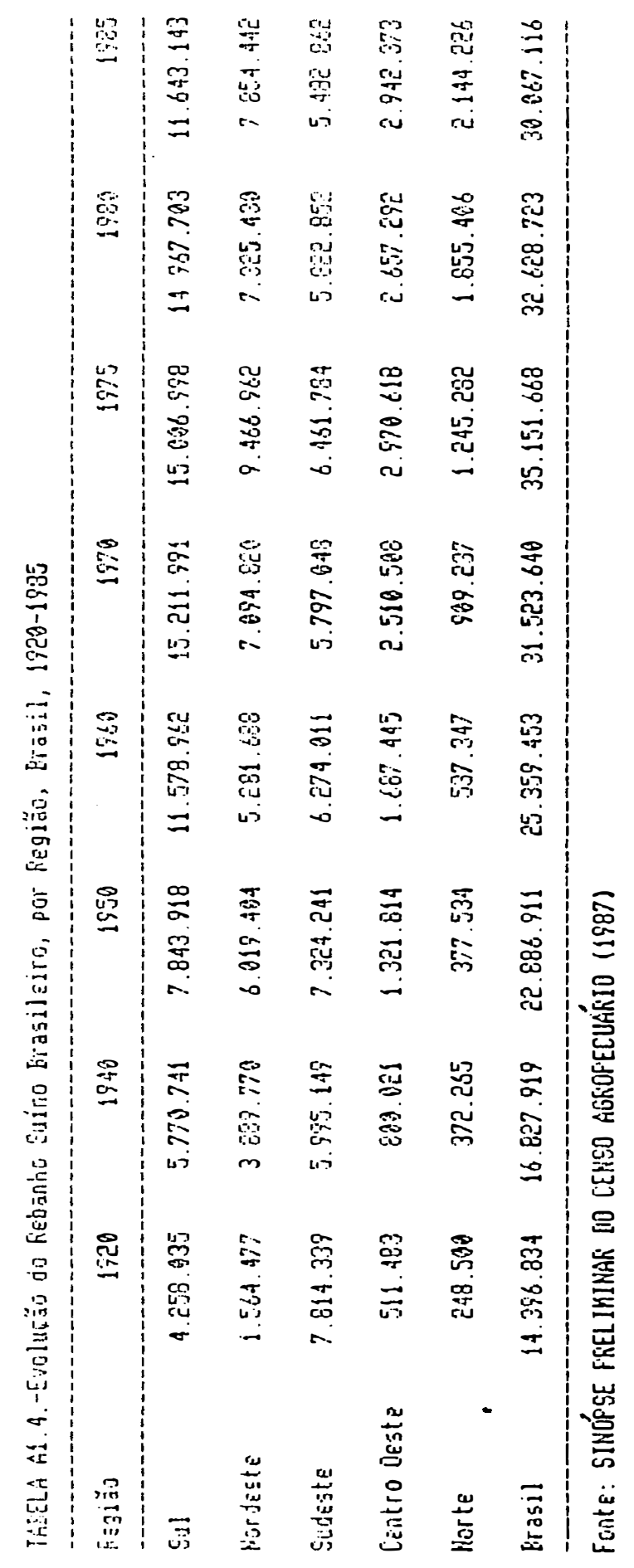


na regjăo, poderá mudạr esse quadro.

lieve-se observar que o aumento dos rebanhos nessa regiăo como tambem nä regiăo rorte provem dä expansăo da fronteira agricola, com a erescente participacăo de produtores sulinos, fato que também acontece na regiăo centromoste, onde implantaram-se grandes projeto: de criacăo e industrializacăo, estimulados por linhas de crédito. Concomitantemente houve, também, a expansăo da cultura de milho nessas regiö́s.

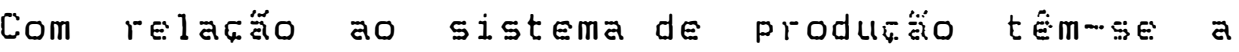
dizer que o semi-confinamento émuto comum em todas as regiótes do Brasil, enquanto a criacăo no sistema de confinamento total apresenta tendência crescente nas áreas de maior tecnificacăo, especialmente no sul e sudeste. Esses dois sistemas caracterizam a grande maioria da sujnocultura tecnificada, que se utiliza de animais de: melhor potencial genético 〈SÃO F'AULO - Secretaria da figricultura, 1976; FAUL, 1977 EFOF'F' 1988).

Quanto à organizaçăo do produtor, constata-se que na regiăo sul grande parte dos criadores estabeleceram-se em sistemas de integracăo ligados às cooperativas e: às indústrias de transformacăo. Nas demais; regióes predominam, tanto na producăo como na comercializacăo, os produtores independentes (F'AUL, 1.97\% FIOFA, 1988).

No tocante ao número de suinos por propriedade, segundo o IBGE, em 1985, 48,14\% possuiam menos de animais; $37,42 \%$ de 20 a 100 e $14,44 \%$ mais de 100 animais. 
- maior percentual de granjas com mais de 100 animais está nat regiäb sudeste sul do pajs (FofFin, 1.980).

Analisando-se as taxas anuais de crescimento por regiăo no periodo $1920-85$ tem-se que, com excecăo da regiăo sudeste $(-0,54)$, todas as demais apresentaram valores crescentes como segue: Nordeste $(2,37 \%)$; Centro-0este $(2,69 \%)$; Norte $(3,32 \%)$ e Sul $(1,54 \%)$. Em temos globais a expansăo no Brasil foi de $1,52 \%$.

Essa mesma análise nos principais estados produtores (Tabela Ai.5) mostra que marantiăo $(4,45 \%)$; Fiaui (3,22\%); Ceará $(3,11 \%)$ e Fará $(2,85 \%)$ apresentaram aumentos expressivos, seguindo-se: Faraná (2,84\%); Santa Catarina $(2,60 \%)$; Goiás $(2,26 \%)$, Bahia $(1,35 \%)$ e Fio Grande do Sul $(0,51 \%)$. Somente em Săo Faulo $(-0,68 \%)$ e Minas Gerais $(-0,55 \%)$ essa evoluçăo foi negativa.

Considerando-se os abates fiscalizados (Tabela Á.6) Vê-se que, em 1987, Minas Gerais, Săo Faulo, Faraná, Santa Catarina e fiio Grande do Sul foram responsáveis por cerca de $85 \%$ do total abatido no Brasil.

Conquanto no Brasil, como um todo, esses abates tenham apresentado, no periodo 1973-87, uma taxa anual de crescimento equivalente a $5,72 \%$, observaram-se aumentos superiores, à essa cifra, em Santa Catarina ( $17 \%$ ) e Minas Gerais $(6,07 \%)$ e menores no Faraná $(5,46 \%)$, filo Grande do Sul $(0,73 \%)$ E Săo Faulo $(0,11 \%)$.

A partir de 1975, vem ocorrendo uma reducăo do rebanho nacional, fato que resulta dos movimentos recessivos da economia brasileira. Entretanto, há de se observar ganhos de produtividade da suinocultura, como se 


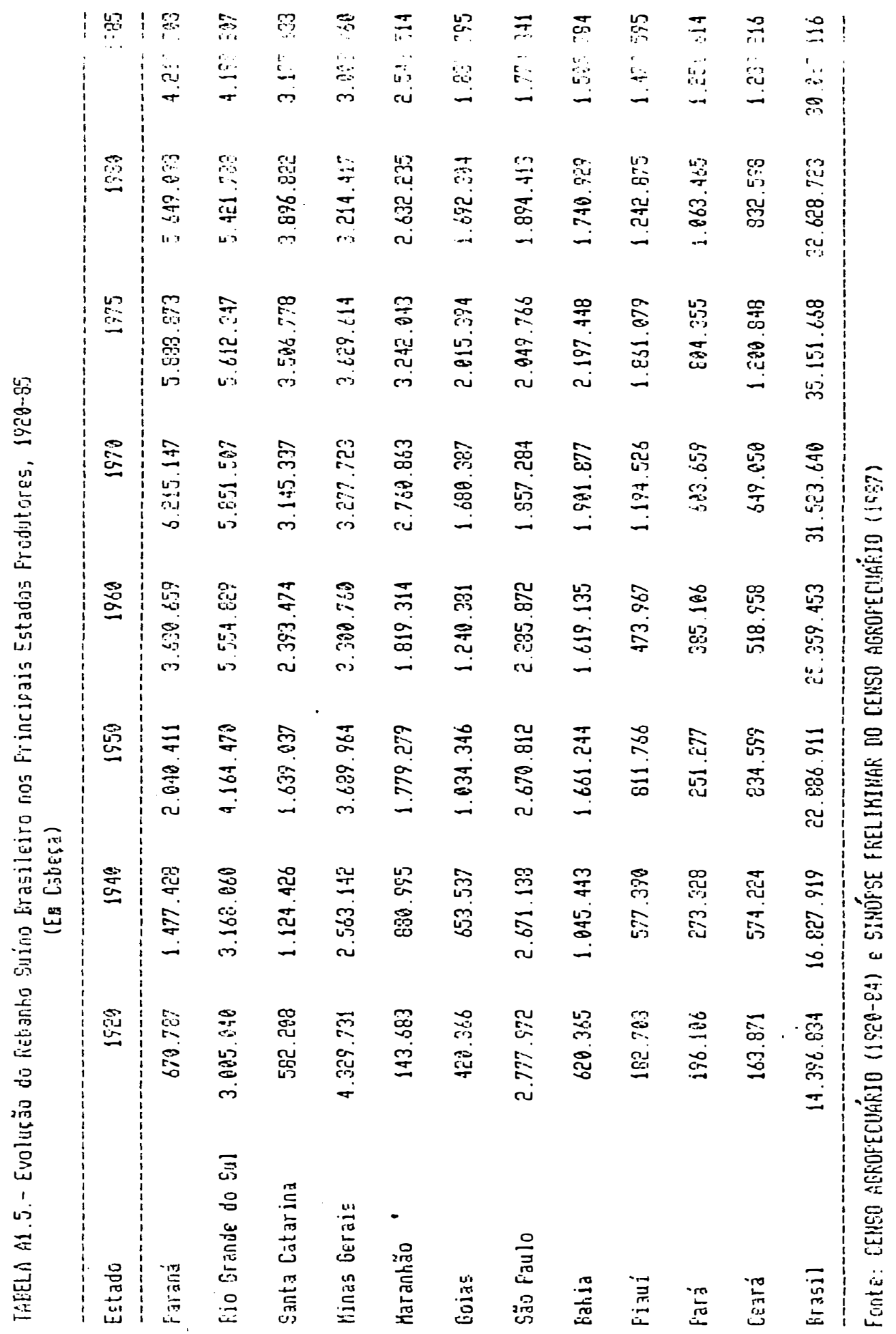




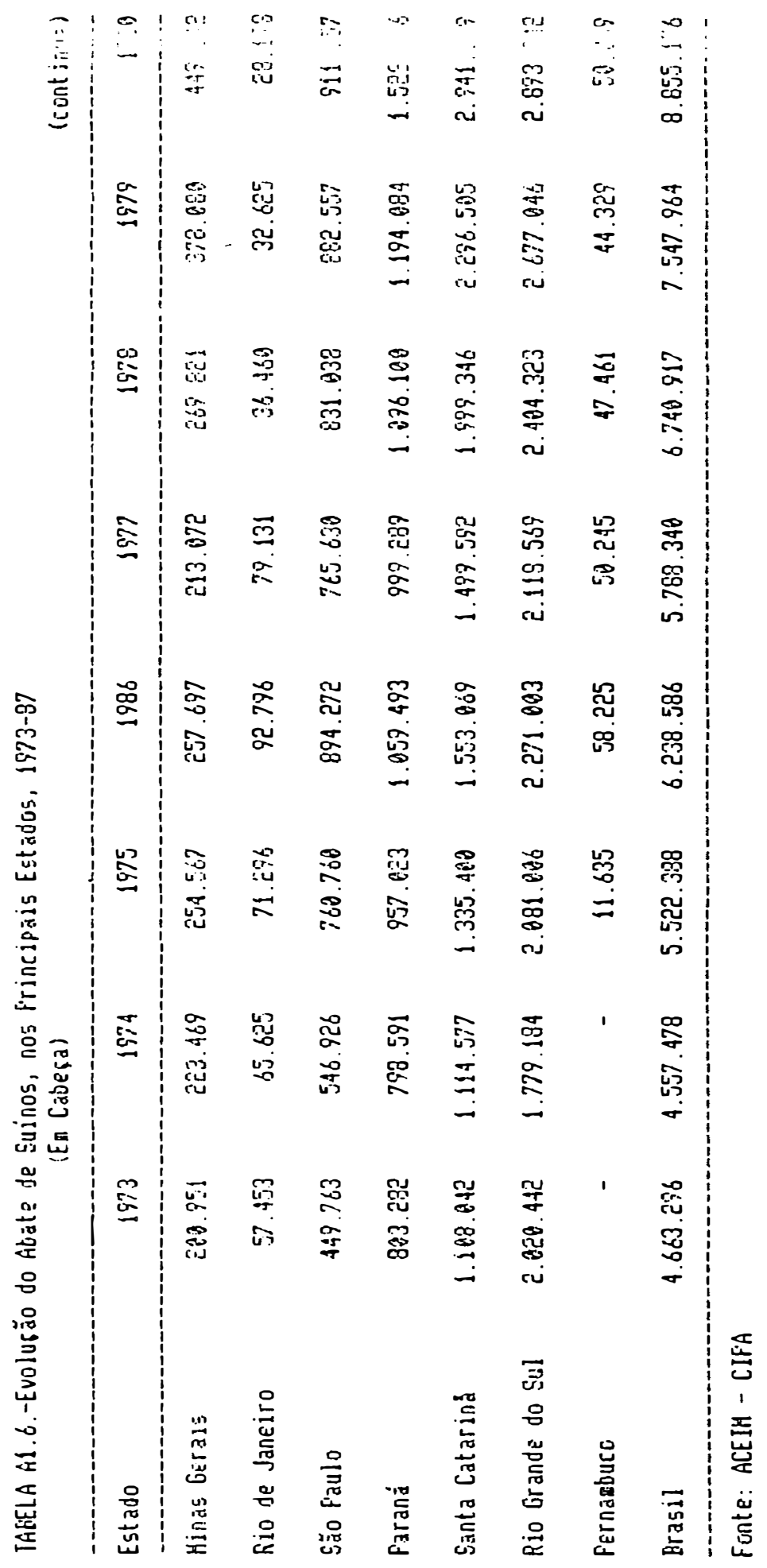




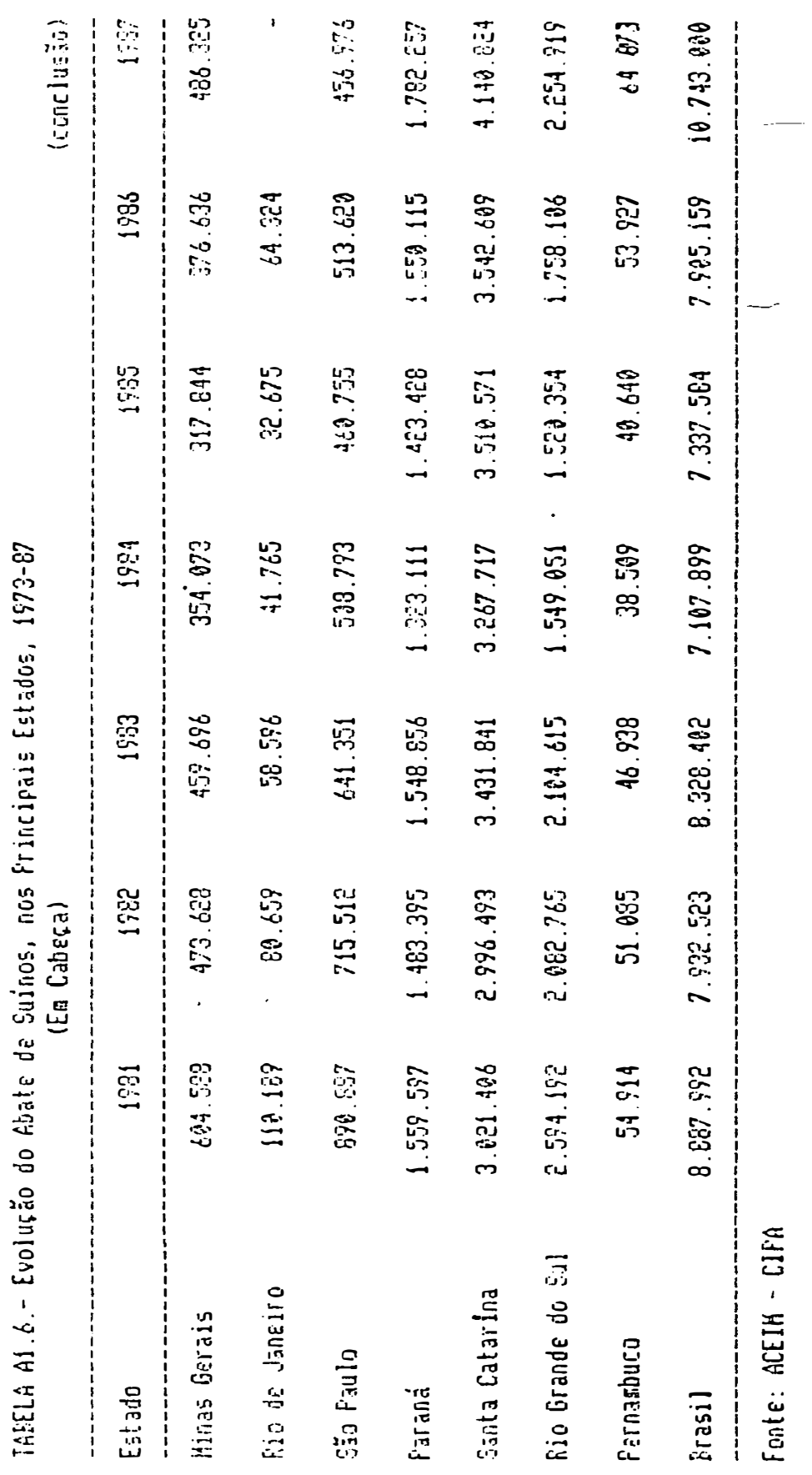


pode depreender das relacóes rebanho e producăo nesse periodo. Isto se tornou mais notorio em 198\% (Tabela A1.7).

A producăo nacional de carne suina atjngiu em 1987 um volume próximo de 1,2 milhóes de toneladas, superando o volume recorde de 1981. Isto decorreu das condicóes favoráveis de mercado e prefos, tanto dos suínos como dos principais insumos, que vinham sendo observadas desde o segundo semestre de 1985 e durante todo o ano de 1986, que estimularam o incremento da producăo e o retorno dos criadores que estavam afastados do processo produtivo (SITUACÃO econômica do mercado de carnes, 1988)

Entretanto, as dificuldades enfrentadas pela suinocultura, principalmente, a partir do liltimo semestre de 1987, implicaram em reducóes de rebanhos. Assim, estimativas, de vários setores ligados a suinocultura, indicavam para 1988 uma retracăo em torno de $20 \%$ no rebanho nacional (ZIFilis, 1988).

\section{A suinocultura no Estado de São Paulo}

Em Săo Fiaulo a carne suina vem participando, nos últimos anos, do rol dos 26 principais produtos da agropecuária paulista:

o rebanho de suínos no Estado de Săo Fiaulo comecou com Martim Afonso de Souza e outros colonizadores que introduziram na capitania de Săo Vicente alguns espécimes da Fenínsula Ibérica. Estes animais. 


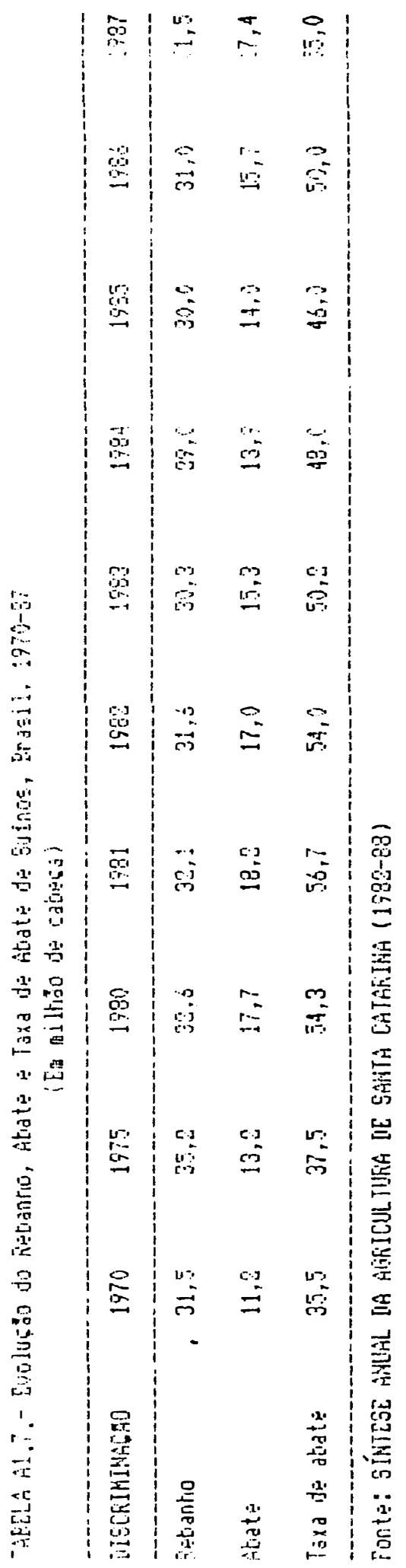


acompanharam os colonizadores na invasăo do sertăo, e

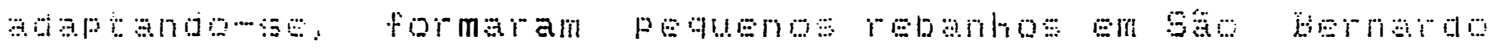
do Campo. Llepois, com os bandeirantes e com as fazendas de café, espalharam-se por quase todo o pais, e formaram as "racas nacionais" (GONINHO, 1981).

É importante que se diga que a partir da biltima década teve injcio no Brasil o programa de melhoramento genético do rebanho, com o estabelecimento do "Filano do porco - tipo carne"(7). Até entăo a criacăo de suínos era extensiva, com a predominância de animais rusticos de baixa produtividade, soltos e criados junto ao milharal. Em 1975 foram desenvolvidos os primeiros programas de hibridos (GOIINHO, 1981).

Há de se acrescer a 1.550 o fato de que, em 1.970 , - Eanco de llesenvolvimento do. Estado de Săo Faulo (BAIIESF) implementou um programa de investimento na suinocultura, cujos principais objetivos, entre outros, eram: elevacăo da taxa de desfrute utilizando-se racas especializadas na producăo de carne (porco tipo carne) e com elevado potencial genético; criacobes intensivas e técnicas adequadas de manejo (AFífú.Jo, 1979).

Fretendia-se, também, induzir a racionalizacăo da atividade em bases empresariais, em termos de distribuicăo uniforme da producăo ao longo do ano $e$ estimulo à integragăo da atividade em diversos niveis ( AFiAÚJJO, 1.979).

(7) Tie acordo com MOUFiA (1985) "Em 1928 a Fazenda fís da Firata em Vinhedo, dava inicio a uma nova fase de suinocultura paulista com a introduc:ăo dos animais tipo carne da raca lluroc". 
Atualmente, contribuem para o criatorio

paulista, formando rebanhos, as racas Landrace, Large

White $e$, em pequena escala, lluroc, Hampshire, Wessex Saddleback. Fiecentemente foram importados os hiridos Humus-Seghers (GOIINHO, 1981).

Ilados relativos a composicăo do rebanho

paulista, sornecidos pelo CENSO AGFOFECUÁfilo, 1920-80 (1920-84), corroboram as afirmacöes citadas, haja visto que a participacăo do porco-carne passou de $15 \%$ do rebanho total em 1975 a $47 \%$ em 1980 (Tabela A1.8).

TABELA A1.8- Composicăo do Fiebanho por Finalidade, Estado de Săo Faulo, 1975-80

(em cabeca)

Tipo

1975

1980

$\bar{C} \bar{a} \bar{n} \bar{E}$

Eanha

Mais de uma finalidade

e engorda

Total $\overline{3} \overline{6} \overline{9} \cdot \overline{3} \overline{7} \overline{3}$

288.761

1. 451.268

2. 049.766 $\overline{8} \overline{9} \overline{8} \cdot \overline{0} \overline{3} \overline{7}$

363.924

1.894 .413

Fonte: CENSO AGROFECUÁ́IIO, 1920-80 (1920-84).

Segundo Fortas (1984), o desenvolvimento da suinocultura no Estado de Săo Faulo deu-se em decorrência da utilizacăo de uma tecnologia avancada, com os criadores oriundos, em sua maioria, do meio urbano. Nessas granjas via de regra, o plantel de matrizes é composto de 50 a 250 animais. Săo utilizados reprodutores selecionados, racăo balanceada $e$ cuidados sanitários eficientes. Contudo, esse quadro favorável năo é caracteristico do Estado, como um todo, onde predomina uma suinocultura com baixos niveis tecnológicos, producăo polarizada com pequeno número de 
suinos em muitas propriedades, como evidenciam dados do

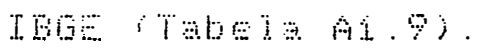

Analisando-se a relaçăo número de cabegas/número de informantes, observam-se os valores de 16,$93 ; 10,96$ e j..$\%$, respectivamente nos censos de j.975, 1.980, es 1.985.

Em relacào ao tipo de informante, vé-se que nă categoria proprietário, que detém o maior número de cabecas, essa relacăo varia entre um minimo de 19,24 (1975) a um máximo de 21,87 (1980).

Considerando-se os giupos de área total tem-se que a maior porcentagem das propriedades (74,7\% a $75,9 \%$ ) possuem áreas inferiores à logha, que correspondem a 4 it alqueires paulistas, caracterizando uma proprjedade de média a pequena.

Quando se associa numero de caberas e informante com área, compreende-se que existe uma relacăo direta entre rebanho e área, pois, em 1985 encontrou-se os seguintes valores de rebanho médio: 13,$72 ; 17 ; 33,57$; 92,82 e 1.844, respectjuamente para os estratos de menos de soha; de 10 a 100ha; de 100 a 1.000ha; de 1.000 a 1.000ha; de 10.000ha a mais.

Outro fato observado em Săo fiaulo éde que a pecuária suina encontra-se disseminada por todo o Estado, como mostra a distribuicão do rebanho, por regiäo agricola: no periodo 1973 a 1987 (Tabela Ailio): muito embora se note a superioridade em termos numericos dos efetivos nas rilfiAs de Campinas, libeirăo Freto, são Jose do Fio Freto, Sorocaba e Marjila. 


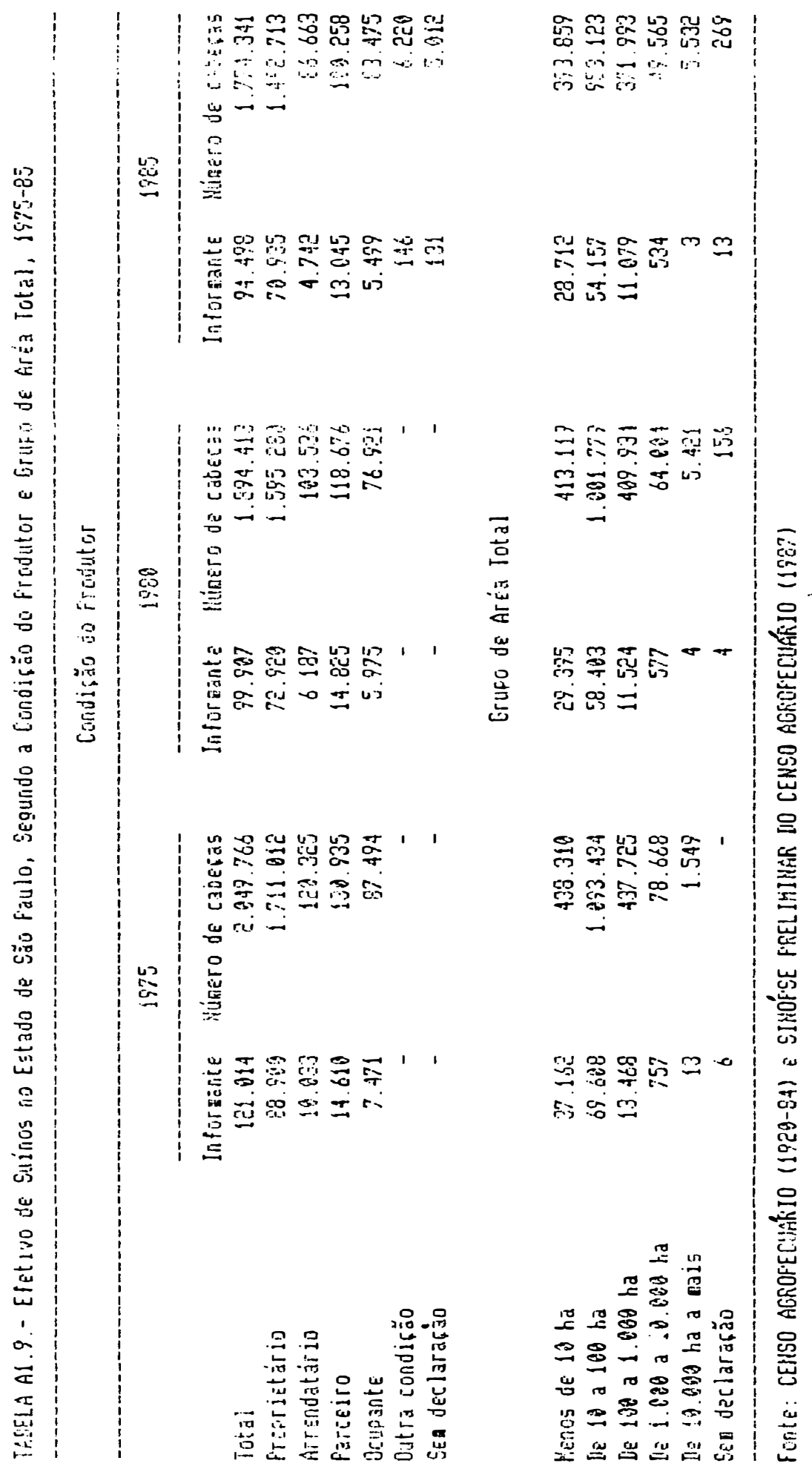




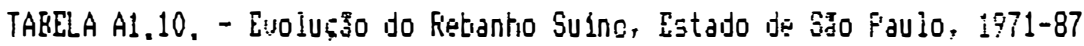

\begin{tabular}{|c|c|c|c|c|c|c|c|c|}
\hline DIFA & 1971 & 1972 & 1973 & $197:$ & 1975 & 1976 & 1977 & 1978 \\
\hline Säo Fiaulo & 39.410 & 47.525 & 37.957 & 54.466 & 43.801 & 43.925 & 49.906 & 41.500 \\
\hline Vaife do Paralta & 79.715 & 58.634 & 68.024 & 69.084 & 72.834 & 95.714 & 96.684 & 82.886 \\
\hline Soroistia & 491.260 & 279.640 & 276.536 & 291.440 & 265.800 & 323.373 & 302.040 & 338.495 \\
\hline Campinas & 298.220 & 253.503 & 258.570 & 273.820 & 262.540 & 235.592 & $882.94 \overline{2}$ & 311.250 \\
\hline Fiturirzo Froto & 181.315 & 258.236 & 245.290 & 228.789 & 253.435 & 282.069 & 224.494 & 289.395 \\
\hline Bauru & 408.260 & 393.187 & 153.590 & 117.518 & 129.042 & 110.870 & 101.380 & 101.300 \\
\hline S.J.do R. Preto & 542.350 & 502.950 & 494.781 & 490.300 & 546.562 & 522.249 & 471.350 & $4: 7.660$ \\
\hline Arasatuba & 125.780 & 147.269 & 132.869 & 136.069 & 132.880 & 139.590 & 130.265 & 135.359 \\
\hline Pros.Prudente & 103.120 & 85.800 & 138.178 & 139.040 & 167.110 & 101.468 & 106.370 & 133.891 \\
\hline Marllia (1) & - & - & 169.442 & 191.852 & 200.600 & 192.000 & 167.400 & 107.150 \\
\hline Total do Estado & 2.269 .430 & 2.026 .744 & 1.975 .237 & 1.998 .378 & 2.074 .604 & 2.096 .350 & 1.938 .771 & 1.969 .898 \\
\hline
\end{tabular}

(1) Antes di 1973, a UIfiA de Marllia estava incluida na de Bauru

Fonte: Instituto de Economia Agricola (IEA) e Coordenadoria de Assistencia Ténica Integral (CATI) 
TABELA A1.10. - Evolujăo do fiztiantio Suino, Estado de Szo Faulo, 197i-87

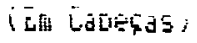

: :0กับ4

\begin{tabular}{|c|c|c|c|c|c|c|c|c|c|}
\hline IIIKA & 1979 & 1980 & 1981 & 1980 & 1983 & 1984 & 195 & $198:$ & 198 \\
\hline STo Fiaulo & 40.875 & 51.768 & 72.648 & 96.360 & 108.150 & 09.650 & 38.710 & 27.497 & $\$ 1,-=$ \\
\hline Vale do Faralba & 60.333 & 62.697 & 59.788 & 55.754 & 55.350 & .53 .980 & 80.380 & 78.538 & 62.3 \\
\hline Sorocaba & 319.875 & 277.650 & 286.563 & 284.813 & 274.500 & 253.550 & 261.391 & 257.240 & 281,04 \\
\hline Campinas & 330.387 & 355.795 & 373.764 & 379.700 & 353.714 & 371.856 & 456.556 & 461.436 & 527.75 \\
\hline Fitreirzo Freto & 246.875 & 265.173 & 258.774 & 225.949 & 237.504 & 219.789 & 230.804 & 235.030 & $23 E_{2}, \mathrm{v}$ \\
\hline Bauru & 109.795 & 110.420 & 97.740 & 100.980 & 103.390 & 91.480 & 79.395 & 89.532 & 80.5 \\
\hline S.J.do Rifireto & 365.549 & 278.230 & 256.297 & 247.815 & 253.882 & 251.120 & 256.054 & 260.216 & 296.80 \\
\hline Ar ajatubia & 105.740 & 123.737 & 102.550 & 116.200 & 95.983 & 99.400 & 80.711 & 73.160 & 73.75 \\
\hline Fros.Prudente & 141.536 & 145.040 & 144.644 & 138.752 & 139.137 & 138.312 & 141.852 & 139.720 & $113.9=$ \\
\hline $\operatorname{Mar} 1 \mathrm{lia}(1)$ & 161.018 & 167.292 & 151.732 & 151.438 & 147.020 & 156.243 & 175.700 & 208.713 & 274.05 \\
\hline Total do Estado & 1.881 .983 & 1.837 .802 & 1.798 .500 & 1.797 .961 & 1.768 .570 & 1.745 .380 & 1.801 .993 & 1.833 .176 & 1.989 .7 \\
\hline
\end{tabular}

(1) Antes de 1973, a BIfiA de Marllia estava incluida na de Bauru

Fonte: instituto de Econoria Agricola (IEA) e Coordenadoria de Assistencia Ténica Integral (CATi) 
Entretanto, é importante que se diga que em

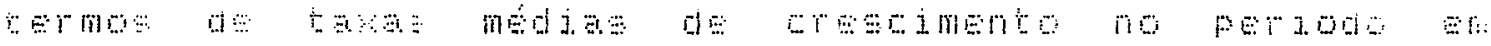
questăo só se obtiveram valores positivos nas lilfias de Campinas $(4,87 \%)$ e marjia $(3,26 \%)$, regiöes en que, segundo estimativas do IEA, em 198\%, existem os majores centros criatórios do Estado, como nas sub-regióne de Bernadino de Campos (Marilia) e Braganga Faulista (Campinas). Ao nivel de Estado o rebanho evoluiu a uma taxa média de $0,05 \%$.

Como nos demais estados, em Săo fraulo a inseguranga a que está sujeita a suinocultura tem provocado grande instabilidade no setor, prejudicando o desenvolvimento da atividade.

Na anälise de pregos pagos aos suinocultores, tem-se a considerar um ciclo produtivo menos definido que - da pecuaria bovina, influenciado por fatores externos, principalmente, prego edisponibilidade do milho e prego de carres substitutas (bovina e: de frango) (figura 1.).

Como resultado de uma relacío de precos porco/milho favorável aos suinocultores, pregos altos dos suinos relativamente aos pregos dos alimentos, ocorre o aumento do rebanho $e$, consequentemente, na quantidade ofertada no mercado. Isto ocasiona, posteriormente, queda nos prefos dos animais, provocando retracăo na atjuidade, com os produtores ajustando sua producăo aos baixos prefos, dando-se a escassez de animais para abate o que implica em novo aunento de presos. 
Assim, a euforia de mercado no periodo 1972-74, com a valorizacăo em termos reais da carne suina $e$ perspectivas de aumento de exportacăo, ocasionaram crescimento da producăo. Contribuiram para esse panorama a crescente demanda do produto, decorrente da escassez no abastecimento de óleos vegetais eda safra recorde de milho, proporcionando maior poder de troca aos criadores (CANTOS, 1977).

No periodo de 1975-76 coincidindo com um pico da oferta de carne suina ocorreu um aumento da oferta de carne bovina acaretando queda nos precos pagos aos produtores. Estes passaram a reduzir seus plantéis, Provocando, com isso, oferta ainda maior e diminuicăo do pręo do suíno (CANTOS, 1977).

A retracăo da producăo em 1977 possibilitou a estabilizacăo da oferta e a consequente reač̆o de mercado. Com os pregos novamente favoráveis a producão retomou seu ritmo de crescimento(FFiOGNóstico, 1978-86).

Em 1978, em fins de abril, foi confirmado o primeiro foco da Feste Suina Africana, o que levou a um elevado abate de animais, pressionando novamente os precos ao nivel de produtor, que em termos reais voltaram a se situar em niveis próximos àqueles registrados em 1976. Fosteriormente, em 1979 as cotafóes do suino aumentaram expressivamente, ao contrário dos pregos relativamente baixos das racóses e do milho, propiciando a estabilizacăo da produqăo (F'ROGNÓSTICO, 1978-1986). 
lá som fo80, mais precisamente no final do ano o aumento sazonal da oferta de suinos coincidindo com a alta

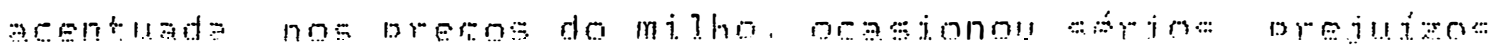
aos suinocultores, além do que em functáo da queda dos precos reais da carne bovina houve forte retracăo da demanda por carne suina.

Esse panorama de pregos reais decrescentes continuou durante 1981 e se năo fosse a abundante oferta de mj.ito o desempento de atividade suinjcola teria giojo bastante desastroso; do lado do consumo agravou-se o quadro desfavorável à carne de porco (FFolinóstico, $1978-\{986)$

For sua vez, a retracăo verificada em 1981 determinou a alta dos prefos dos suinos em 1982. Em 1983 a escassez do milho, aliado à menor demanda de carne levou, os criadores a um descarte nos rebanhos, tanto a nivel de matrizes, como de suinos tjpo carne. Os altos custos da alimentacăo dos animais năo puderam ser repassados ao produto fjnal, reduzindo-se assjm a lucratividade do setor. A partir de fevereiro de 1984 , houve uma melhoria no desempentro da atividade, em razăo da queda do preco do milho e da retracăo na oferta de suinos, elevando os fiecos destes no mercado. Em 1985, a relatjua estabilidade do item alimentabío proporcionou boa rentabjlidade a suinocultura com reflexos positivos no processo de recuperacăo do rebanho e abates em 1986 (FFOGNÓSTICO, 1978-1986 E ANÁLISE Economica sobre a situaçăo da suinocultura, 1986). 
Apesar da recuperacăo real dos preqos recebidos pelos suinocultores em 1986 (Figura 2 ), observa-se que em termos médios foram inferiores aos observados em $1974 \in$ 1979, anos de alta ciclica nos preqos da carne bovina.

Após a euforia do plano cruzado, com a queda no poder aquisitivo, verificou-se retracăo no preco real do suino, notadamente a partir de marqo de 1987 e que se estendeu durante o ano de 1988, provocando o fechamento de cerca de 30\% nas granjas no Estado de Săo Faulo (SITUACÃO econômica do mercado de carnes, 1988 e ZIRLIS, 1988).

some-se a esta situacăo de desestimulo, o fato de que os precos minimos do milho săo atualmente corrigidos pelas variacões das obrigacões do Tesouro Hacional (OTW), $e$ os pregos do farelo de soja e de micro-elementos, necessários a fabricacăo das racões, também sofreram aumentos acompanhando a variacăo cambial.

É necessário enfatizar que esse quadro atual deverá trazer reflexos no plantel, abates e producăo nos Próximos anos.

o desempentro econômico da atividade pode ser aferido através da relacăo de precos porco-milho. Um fato observado é de que nos liltimos anos, mais precisamente a partir de 1980-81 as recuperacótes ocorridas nestas relaç̌ลs năo tem sido suficientes para ocasionar aumentos nos abates fiscalizados, como se observa na figura 3 , mostrando que os produtores, ao contrário do que afirmado anteriormente, têm sido cautelosos ao programar suas producóes. 


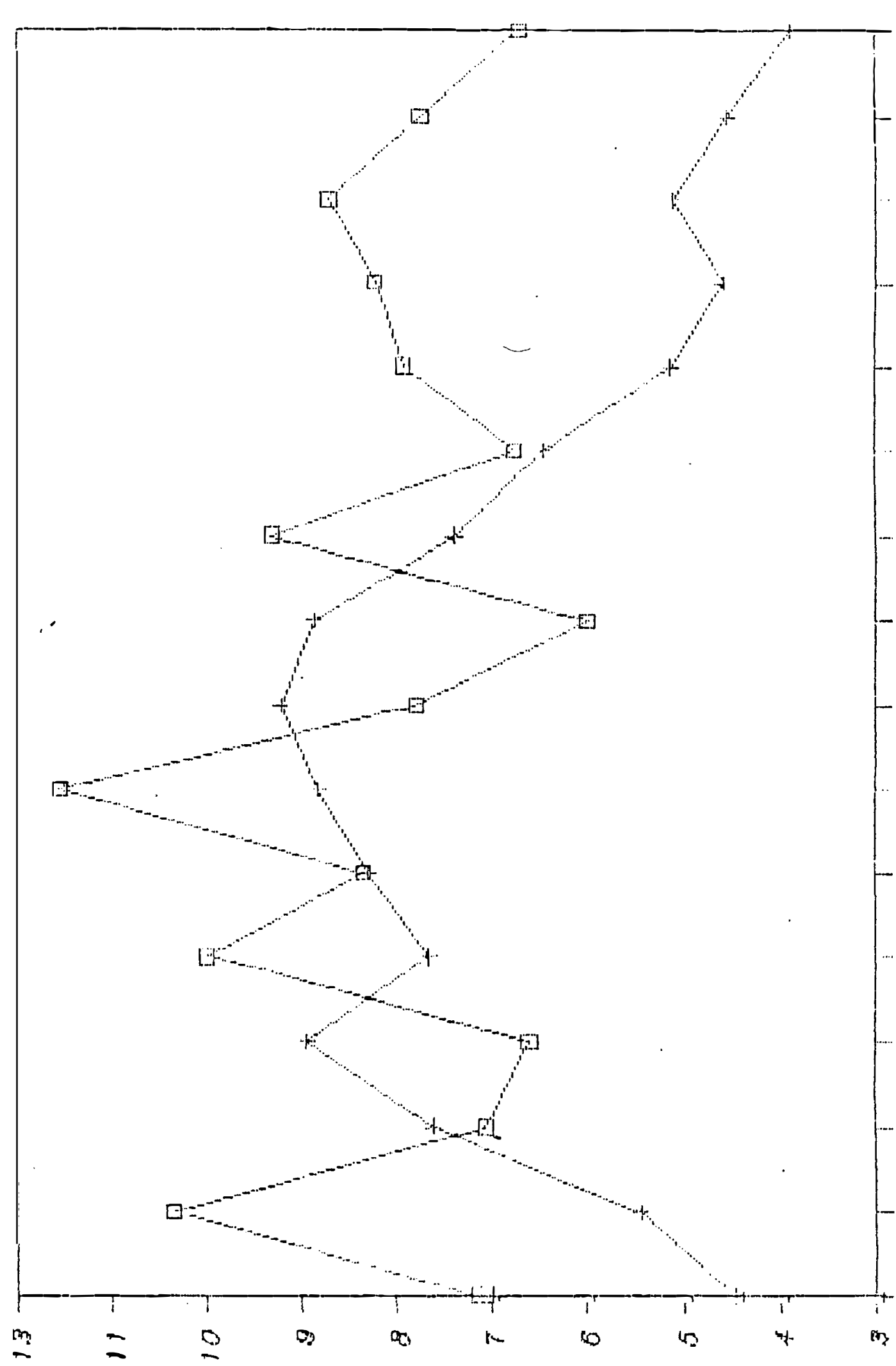

as

c)

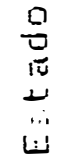

N

$\infty$

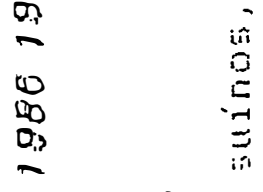

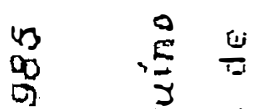

- in

के षे

0 is

in

O)

-

$\infty+\vec{E}$.

2

2

0

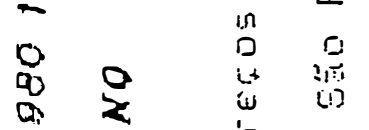

$-\frac{1}{4}$

a

a

$-$

as

a

2

n

r

$20 \pi$

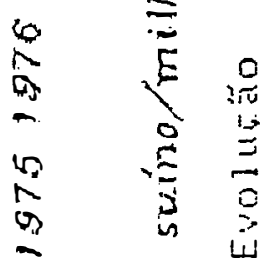

* > 8

$\frac{1}{2} \quad \frac{5}{2}$

$m 5$

a

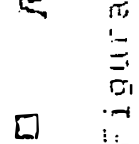




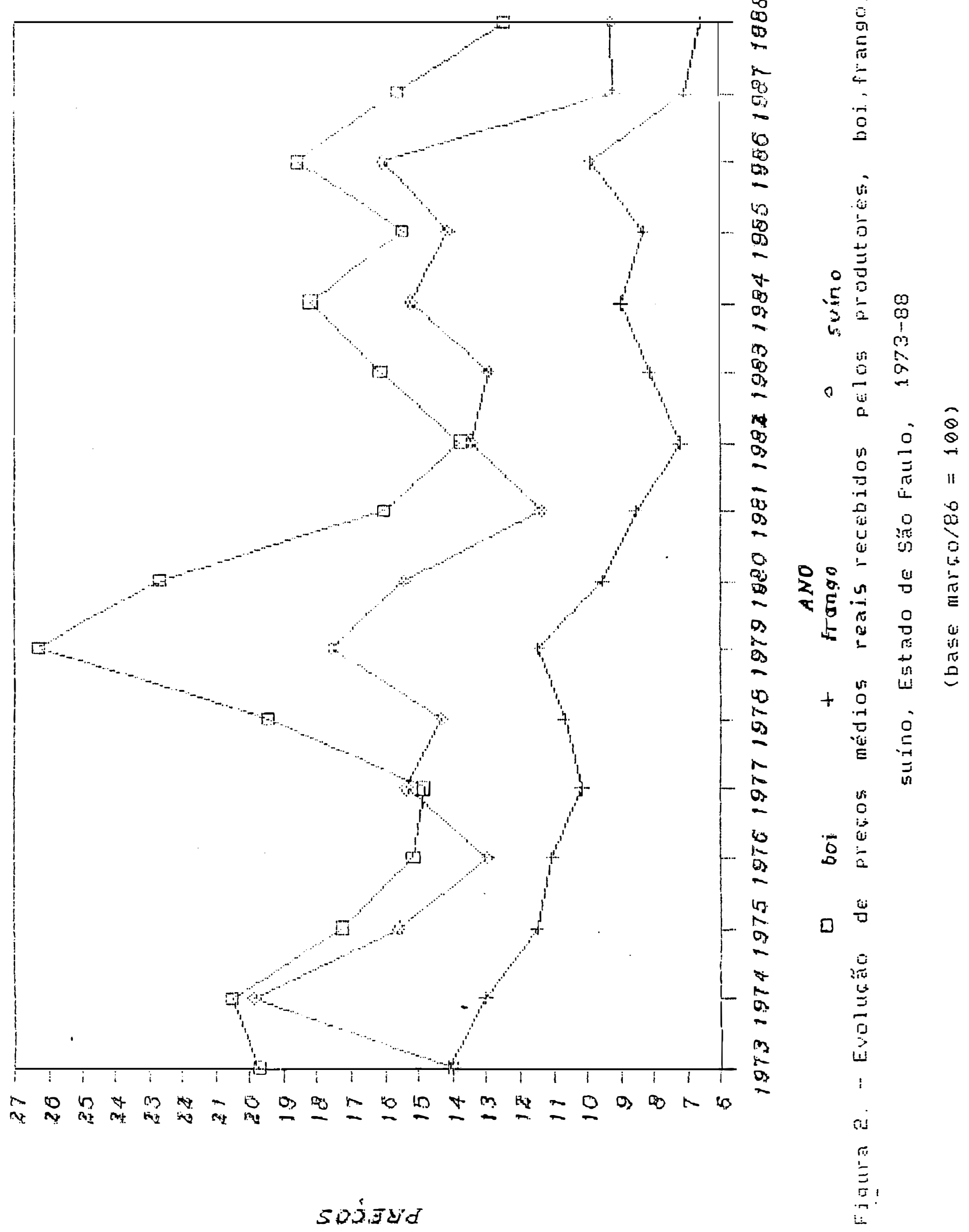


Analisando-se comparativamente a evolucăo dos precos recebidos pelos produtores de suínos, bovinos $e$ frangos, (Figura e) nota-se que via de regra os precos das aves $e$ do boi tendem a apresentar variacóos no inesmo sentido, já os prefos do porco mostram comportamento mais independente em relaçăo à carne bovina, explicado, em parte pelo elevado grau de industrializacăo desta carne.

Sendo assim, é comum que em anos de menor oferta de suíno vivo, independentemente da tendência de preços de outras carnes, observadas ao nivel de varejo, o preco pago ao produtor sofra elevacöes, visto que as industrias prescindem de uma quantidade fixa de matéria-prima. Fode-se citar como exemplo o ano de 1982 que, ao contrairio do acontecido no setor avicola, foi bastante favorável à suinocultura.

Sobre esse aspecto, dados apresentados no Congresso da Fauliscarne, em 1987 mostram que $70 \%$ do consumo da carne suina no Brasil é sob a forma industrializada $\varepsilon 30 \%$ in natura (F'OF'A, 1988).

Esse mercado de carne suina associada a tradifăo de venda "in natura" das partes mais nobres do suino (lombo e pernil) constituem um fato agravante para a suinocultura, uma vez que disputa com a bovina os prefos mais altos no comércio de proteinas animais, (Tabela Ai.11), dificultando desse modo a expansăo de seu consumo, apesar da carne de porco progressivamente deixar de ser mais cara, equiparando-se aos da carne bovina. 


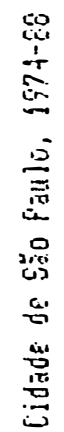

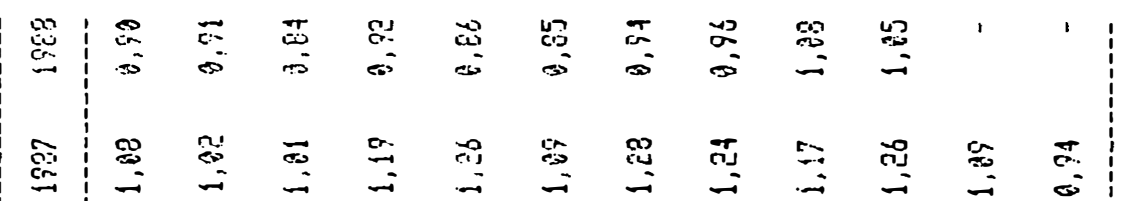

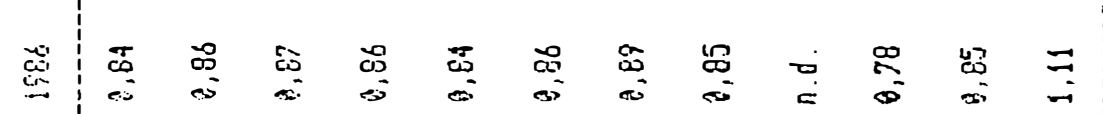

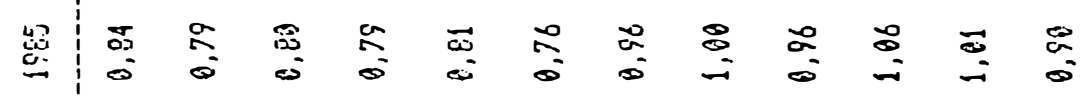

cin

胥 管

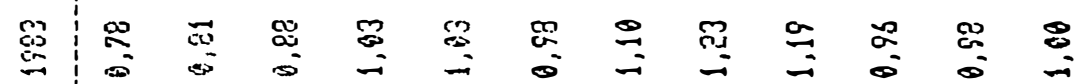

यis

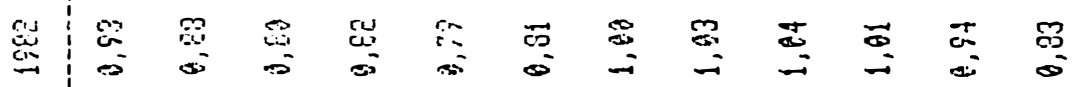

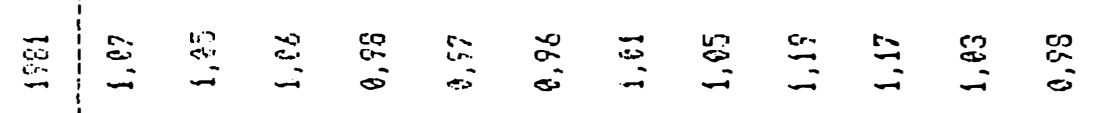

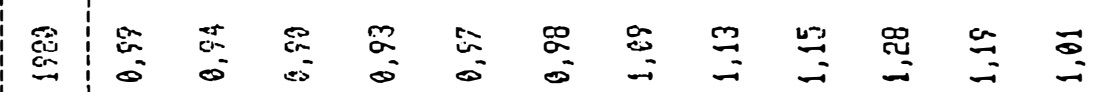

营

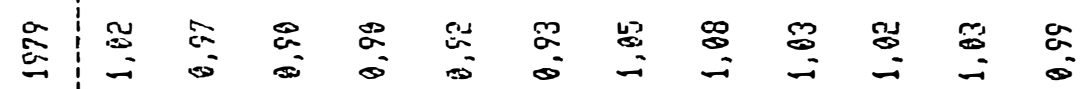

总

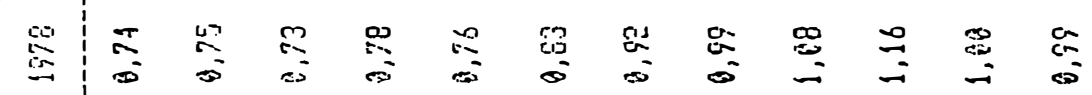

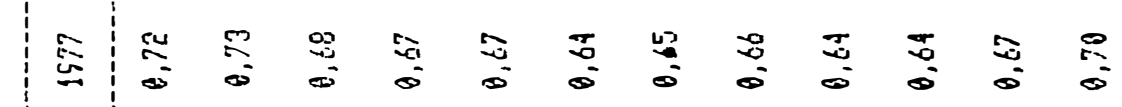

总

峞

岕

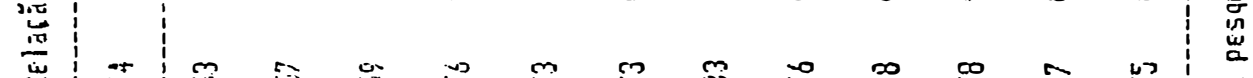

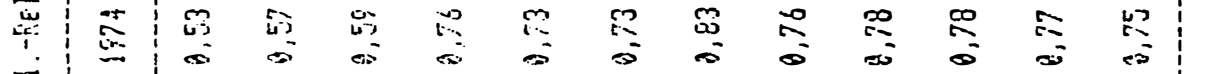

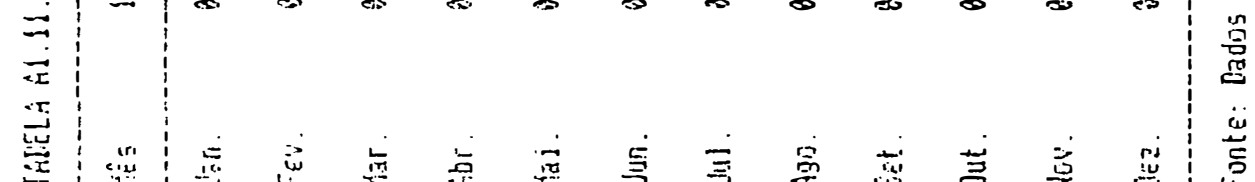


BFANIT et alii ( 1.987 ) em trabalho sobre ciclos $E$ integracáo no mercado de carnes, encontraram como resultado a existência de maior eficiência de ajuste às variacóes em precos de carne bovina do setor avicola, quando comparado com o ajuste observado no setor de: suinocultura, corroborando as constatacöes anteriores. 
ANEXO 2. CARACTERIZACÃO DAS

UNIDADES PRODUTORAS DE SUÍNOS NO ESTADO DE SÃo PAULO 
Região de Marilia: sub-região de Durinhos

Área de estudo:

os municipios abrangidos nesse trabalto foram os de Fartura, Taguai e Sarutaiá pertecentes a relegacia Agricola (DA) de Eernardino de Campos e Timburi que faz parte da lia de ourinhos. Fara fins de analise da presente pesquisa, acompanhando tambem trabalho de CAMAFigo (1983), essas duas delegacias foram agrupadas em uma linica, ou seja, Durintios.

As principais atividades na lira de marilia săo: trigo, mandioca, soja, amendoim da seca, amendoim das águas, café, milho, arroz, tomate rasteiro, feijăo da seca, kangerina, feijăo das águas e mamona (CAMAfigo, 1983). Na sub-regiăo de ourintos destacam-se: café, milito, cana, soja, arroz, trigo, fej.jăo da seca, algodão, feijăo das águas e mandioca (CAMAFigo, 1.983).

Em 1987, levantamentos do Instituto de Economia Agricola (JEA) indicavam para o Estado de Săo Faulo um etetivo suino ao redor de 1.989 .000 animais, com arfa de 
Marilia participando rom j.s, $7 \%$ desse total. Mas R.A. de Bernardino de Campos e Ourinhos observaram-se,

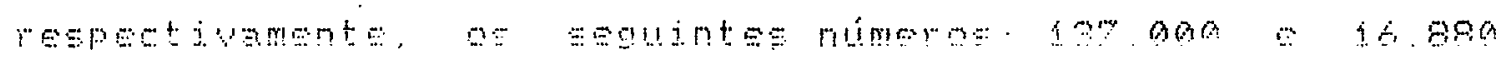
animais, o que representa $49,48 \% \in 6,45 \%$ do rebanho observado na IIIFiA de Marilia.

\section{Caracteristicas gerais da propriedade e do proprietário:}

A área total de ada propriedade wariou entre a 41e alqueires, encontrando-se um tamanho médio de 36 al queires.

Um fato observado é de que nas propriedades com áreas inferiores a 4 alqueires (25\% da amostra), a. principal atividade comercial é a suinocultura. Fara as demais a participacăo da suinocultura na receita total variou entre $20 \%$ a $80 \%$, com média de $42 \%$. As outras atividades mencionadas foram: café, grăos (principalmente milho) $E$ bovinos.

Quanto ao estágio de producăo têm-se que $93 \%$ dos casos estudados encontram-se em producăo e $7 \%$ em implantacăo. Llas que se encontram ent producăo, $68 \%$ acham-se em expansăo, $28 \%$ em estabilizacăo e $4 \%$ retornando à atividade.

0s fatores citados como limitantes para aumento de producăo efou melhoria genética do rebanho foram, em ordem decrescente de importancia: baixos precos recebidos; falta de crédito; falta de reprodutores; problemas de abastecimento do milho, notadamente na entressafra 
doenfas.

Quanto ao tempo na atividade, este variou entre:

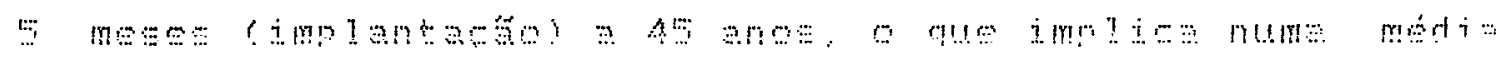
de 10 anos. Analisando-se os informes individuais tem-se: que $68,96 \%$ dos proprietarios estăo na faixa até 10 anos $89,65 \%$ na faj.xă de até 15 anos.

\section{Informacões sobre comercialização:}

Na comercializac̆ăo dos animais o sistema de: vendas utilizado é o de peso vivo, usando-se um percentual de $20 \%$ de desconto para se chegar ao peso morto.

o sistema de pagamento é, em sua maioria (79\%), a prazo, com variabilidade de 8 a 20 dias, sendo o mais comum de is dias.

Quanto aos fatores usados para se estabelecerem os precos, tem-se que em 100\% dos casos é observado o peso do animal.

Os locais de comercjalizacăo săo preponderadamente próximos às regiöes de producăo; no entanto, além destes, foram cjtados: Săo Faulo, kotucatu $\varepsilon$ : Săo José do Fio Firexo.

os agentes envolvidos na comercializacăo săo os intermediários $(71 \%)$, seguindorse os acougueiros, abatedouros e frigorjfjcos inspecionados. 
Quanto à finalidade de criacăo, tem-se que $100 \%$ dos entrevistados săo criadores de ciclo completo.

Ila análise da composicăo racial do rebanho (Tabela A2.1), observamse a predominância das ragas Landrace $e$ Large White, no caso dos machos e Landrace $e$ cruzamento entre ragas para as fêmeas.

TAEELA A2.1- Composigăo Fiacial do Fiebanho, Fiegião de Ourinhos, Estado de Săo Faulo (em porcentagem)

Riaca rluroc Landrace Large White Wessex Hampshire racas

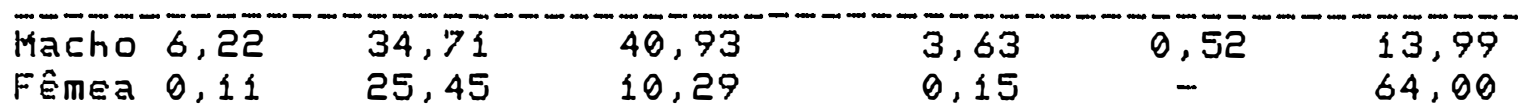

0,15

64,00

Fonte: Ilados da fesquisa

Considerando-se o numero de fêmeas, observou-se que este variou entre 10 a 290 , com nuimero médio de 93 animais. Quanto aos machos tem-se um efetivo entre 1 a 14 animais, em média 6 .

o rebanho total de fêmeas somou 2.664 animais $E$ - de machos 173, assim sendo a relacăo macho/fêmea é de 1.:15. Wo entanto, analisando-se este informe individualmente detectou-se relacóses variando entre 1:6 a i: 22 .

Com relacão à porcentagem de descarte de matrizes e cachacos por ano, o indice mais frequente esteve entre 20-25\%. 


\section{Índices médios de produtividade}

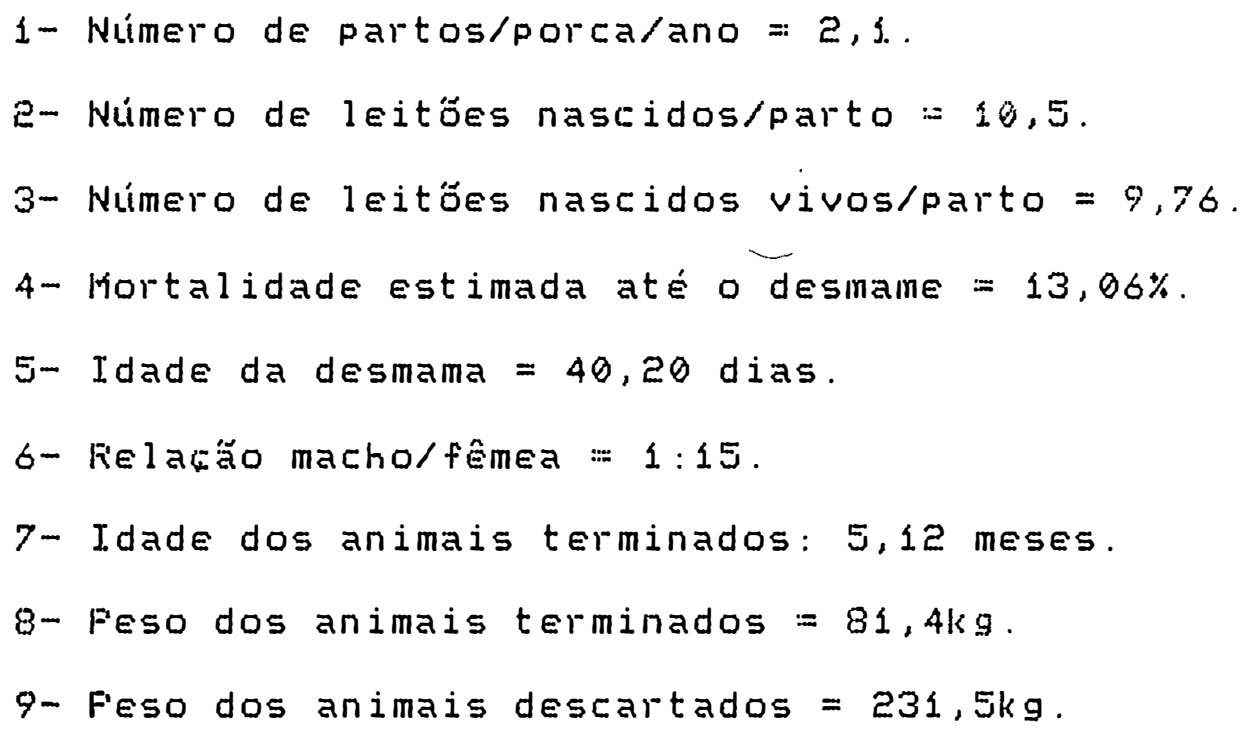

\section{Al imentạão:}

Ila análise das informacóes tem-se que săo utilizadas pelos produtores formulacóes de racóes a base de concentrados, super concentrados, núcleos e prémix vitaminicos e minerais. o uso de racăo balanceada pronta só foi detectado na categoria inicial, ou seja leitóes.

Além do milho que se constitui no elemento básico das rafóes, observou-se, de forma geral, o emprego dos seguintes ingredientes: farelode soja; farelo de arroz; soja; leite de soja; leite em pó; farinhal de carne; soro de leite; sal mineral; sal comum; vitamina $A$ laE, 
aquicar e cobre.

Milho:

Constatou-se que somente $1.4 \%$ dos componentes da amostra produzem 100\% do milho consumido na propriedade; 28\% compram todo o milho consumidoe os $58 \%$ restantes produzem milho numa proporgăo que varia entre 10 a $80 \%$ das necessidades

Quanto aos locais de aquisicăo tem-se que $75 \%$ dos entrevistados compram o milho na própria regiăo e o restante em Goiás, Săo faulo e governo, através da CFF'.

Quanto a época de aquisicăo do milho tem--me que $34 \%$ dos proprietários adquirem milho todo mês e os $66 \%$ restantes de dezembro a maio.

llos que se utilizam da armazenagem, $43 \%$ estocam milho a granel, $39 \%$ estoram o milho ensacado e $18 \%$ de forma ensacada $e$ a granel, e destes $80 \%$ possuem armazenamento próprio.

Mão de obra

Nesse item observa-se uma relaquăo direta entre tipo de mão de obra e tamanho da propriedade crelacionada com numero de matrizes). Llesse modo em $13,8 \%$ dos questjonários com até 15 matrizes é empregada a măo-de-obra basicamente familiar, para as demais 
măo-demobra familiar e/ou contratada.

0 valor dos salários varia entre 1 a 1,5 salarios minimos: chegando a e-2. encarregado ou gerente.

Higiene e profilaxia:

As doencas mais comumentes observadas, săo: Finite Atrófica, Fleuro-Fneumonia, Gastroenterite, Erisipela, Endoparasitose e Brucelose. Também observaram-se afeccóes ligadas a manejo e alimentacăo como Stress e Canibalismo.

Os exames feitos com certa freqência săo: Brucelose e Leptospirose. Outras análises realizadas săo as de água, fezes e matéria prima da racăo.

As seguintes vacinas săo mencionadas, em ordem decrescente de utilizacăo: Feste Suina, Faratifo, Finjte Atrófica, Aftosa e Antibacteriana.

Os medicamentos utilizados incluem o ferro para leitóes, verinifugos, indutores de parto, sarnicidas, antibióticos, etc. 
Instalacões e equipamentos:

- Fara os cacharos ae instalaroses possuem área variando entre 4me a 12me/cabeca, com área média de $7,8 \mathrm{~m} 2$.

- Fara as fases de préngestacăo e gestacăo observou-se tanto o sistema convencional em baias individuais $e$ coletivas, quanto o uso de confinamento em gaiolas.

- Na maternidade é usada com bastante frequência o sistema de gaiolas.

- Quanto aos piquetes foi observado em mais da metade das propriedades, exclusivamente para as categorias machos $e$ fêmeas reprodutoras.

Quanto a outras instalacóes existentes foram observadas as seguintes: depósito fábrica de racăo, pediluvio, embarcadouro e esterqueira.

No tocante aos silos, observado em $34 \%$ das propriedades (com rebanhos superiores a jo matrizes), a capacidade variou entre 100 a 720 ton., média de 445 ton. o material empregado na construcăo do silo é o zinco galvanizado (metal).

As instalacöes complementares observadas foram: casas de empregados, escritório e reservatório de água.

Equipamentos especificos incluem principalmente o triturador, misturador de racão, seguindo-se: balangas para racão e pesagem dos animais, lanca-chamas, pulverizadores, alicates, seringas revolver e descartável, geladeiras e carrinhos. 
Equipamentos

complementares:

veiculos

utilitários, caminhonetes, caminhăo, trator, carretas, tanque para carregar esterco, bombas e motores.

\section{Região de Campinas - sub-região de Braganca Paulista}

\section{Área de estudo:}

Este estudo abrangeu a lijif de Campinas, Llelegacia Agricola de Braganca Faulista $e$ os municipios de Braganca Faulista, Fedra Bela, Finhalzinho, Vargem Grande, Atibaia, Joanópolis, Nazareth Faulista, Firacaia $e$ Bom Jesus dos F'erdốes.

As principais atividades agricolas na riJfiA de Campinas săo: tomate envarado; tangerina; algodăo; laranja; limão; batata das águas; batata da seca; batata de inverno; cebola; cana; uva; mandioca; arroz; milho; café e pastagem (CAMAFGO, 1983).

Na sub-regiăo de Braganga fraulista os produtos expressivos săo: milho; café; feijăo das águas e seca; arroz; batata das águas, seca e inverno e pastagem (CAMAFIGO, 1983).

Em 1987, 26, 5\% do rebanho suino do estado achava-se concentrado na liira de Campinas. A llelegacia.de Braganca Faulista, com um efetivo de 85.800 animajs, respondeu por $16,2 \%$ dos suinos existentes na llira de: Campinas. 
Caracteristicas gerais da propriedade e do proprietário.

Em be\% das propriedades da amostra a suinocultora constitui-se na atividade principal; nas $38 \%$ restantes a participaqăo variul entre 30 a $90 \%$, e nesse caso as outras exploraqöes enunciadas em ordem decrescente foram: bovinos para corte e leite; café; gräos (milho); eucalipto e aves.

A área total variou entre 0,2 a 50 al queires.

A totalidade das propriedades da amostra encontra-se em plena producăo, e dessas $46 \%$ estão estabilizadas, $34 \%$ em expansăo e $20 \%$ em retracăo, isto em relacăo aos liltimos cinco anos.

Como fatores limitantes do aumento de producăo ou melhoria genética do rebanho, foram citados as baixas relacóes de troca do setor spregos recebidos pelos suinocultores/pregos pagos dos insumos).

- número médio de anos na atividade é de 13 anos, observando-se que $50 \%$ dos proprietarios encontran-se na faixa de até 10 anos na suinocultura, e $81 \%$ na de até 15 anos. 
Informes sobre comercializaça:

Freponderantemente as vendas de animais săo realizada: em peso vivo, havendo um desconto de $20 \%$ para PEso morto.

Quanto ao sistema de pagamento $84 \%$ vendem a prazo (10-15 dias) e 16\% a vista.

llentre os fatores utilizados para estabelecimento de precos, destacou-se o item peso $(95 \%)$, seguido pela pelagem, havendo preferencia pela de cor branca.

Ds locais de comercializacăo mais mencionados foram: Braganga Faulista, Suzano, Itapecerica da Serra, Santo André, Carapicuiba e Vale do Faraiba

Ile acordo com os informantes a venda de animais para abate é feita para frigorificos, intermediarios, marchantes e acougues. A venda dos reprodutores é feita na própria propriedade.

o frete de transporte dos animais terminados, segundo os entrevistados, fica por conta do comprador.

\section{Dados de exploracão}

Em 24\% das propriedades visitadas a finalidade principal da exploracăo é o de criacăo de leitöes para posterior venda aos terminadores. Ds demais săo criadores de ciclo completo, com alguns se dedicando também à venda de leitöes e reprodutores. 
Quanto ao escalonamento da producão foi

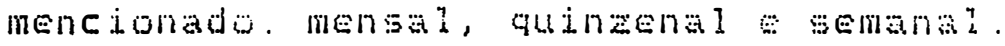

Na composicăo racial do rebanho prevalecem as racas Landrace $e$ Large white, no caso de machos $e$ o cruzamento entre racas e Largle White nas fêmeas (Tabelà Aㄹ. ㄱ.

TABEla A2.2. - Composicăo Fiacial do Fiebanho, fiegiăo de Braganca Faulista, Estado de Săo Faulo (em porcentagem)

Fiaca lluroc Landrace Large White Hampshire wessex racas

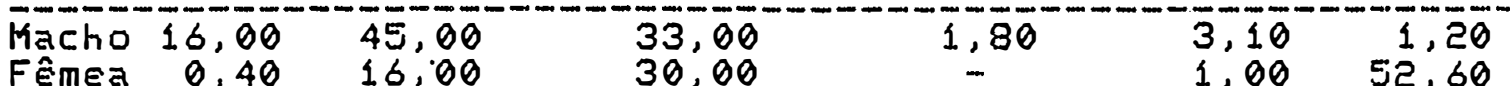

Fonte: llados de f'esquisa

o número de machos variou entre 1 a 37 , com uma média de 7. No caso dás fêmeas observou-se o mínimo de 10 e o máximo de 500, com média de 100 animais. Em termos globais obteve-se um rebanho de 2.997 fêmeas e 224 machos reprodutores, o que ocasionou uma relacăo macho/fêmea de $1: 13$.

Analisando-se as informacóes individuais na relacăo acima, por propriedade, constataram-se valores entre $1: 6$ a $1: 28$.

A porcentagem média de descarte de fêmeas e machos esteve entre $20-25 \%$. 
Índices médios de produtividade:

1- Número de partos/porca/ano = 2,07.

2.- Numero de leitóes nascidos/parto $=10,5$.

3- Número de leitóes nascidos vivos/parto $=9,45$.

- 4- Idade de desmama $=36,4$ dias.

5 - Mortalidade estimada até a desmama $=10,6 \%$.

6- Fielą̧ăo macho/fêmea = 1:13.

7- Idade média dos animais terminados:

a) caso dos criadores de leitóes $=60$ dias.

b) caso dos criadores de ciclo completo que também vendem leitŏøs: animais terminados 5,5 meses $€$ leitöes 70 dias.

c) eriadores de ciclo completo que também vendem reprodutores $=5$ meses tanto para reprodutores, quanto animais terminados.

d) criadores só de ciclo completo: = 171,18 dias.

8) peso médio dos animais terminados $=92,7 \mathrm{~kg}$.

9) peso médio dos reprodutores machos e fêmeas descartados $=249,25 \mathrm{~kg}$.

Al iment ação:

Assim como la regiăo de karilia os casos observados de arrocoamento dizem respeito ao uso de concentrados, superconcentrados, núcleos e prémixes vitaminicos-minerais. A utilizacăo de racăo balanceada pronta só foi observada para os leitóes até o desmame, mostrando-se uma prática bastante comum no caso dos 
criadores de leităo.

Em termos globais os ingredientes empregados pelos produtores săo: milho, farelo de soja, farelo de trjog, farjuha de carne, acucar, sal, sal mjneral, calcário, vitaminas, fosfato bicálcio, aminoácidos e leite Em Pó.

E prática comum o emprego na racăo de vermifugos, antibióticos, quimioterápicos, etc.

Milho:

Em Eraganca Faulista $60 \%$ dos entrevistados compram todo o milho, e para os demais (40\%) nenhum deles produz todo o milho consumido na propriedade. Fara esse liltimo caso têm-se que em média săo comprados $87,5 \%$ do milho necessário e produzidos $12,5 \%$.

Como locais de aquisicăo, desse milho, foram enumerados além da própria regiăo $(70 \%)$, a Eolsa de Cereais e CEAGESF $(23 \%)$ e Faraná $(7 \%)$.

Quanto a época de aquisiqăo do cereal, $52 \%$ dos suinocultores adquirem na safra; $30 \%$ todo o mês e $18 \%$ năo tem época definida, comprando quando necessário.

A forma de armazenagem encontrada para o milho segue a seguinte distribuigão : $50 \%$ ensacado, $43 \%$ a granel e $7 \%$ a granel e ensacado.

- armazenamento próprio ocorre, nas propriedades com rebantio superior a 20 femeas. 
Mão de obra:

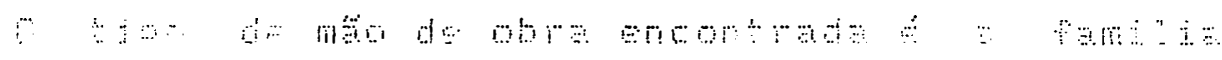

(24\%) E familiar e/ou contratada ( $76 \%$ ).

0) salário médio encontrado variou entre 1 a 1,7 salários minimos.

Higiene e profilaxia:

As doencas mais comuns na regiơ sỡo:

Fleuropneumonia e Gastroenterite.

Quanto aos exames realizados tem-se: Brucelose, Leptospirose, e análises gerais (fezes, raföes, etc.).

As vacinas mais utilizadas săo: F'este suina, Faratifo, Aftosa $e$ Finite Atrófica.

Constatou-se que os medicamentos usados pelos suinocultores săo: vermifugos, ferro para os leitóes, antibiótj.cos, sarnicidas, vitaminas, etc.

Instalacões e equipamentos:

Fara os cachacos a área das instlacöes valiou entre 4 a 12me, em média a área foi de $7,43 \mathrm{~m} 2$.

As instalabóes para porcas pré-gestantes gestantes compreendem tanto as baias convencionais quanto as gaiolas, as quajs são utilizadas com bastante 
frequência nas maternidades.

Ds piquetes quando existentes săo restritos para as categorias machos e femeas reprodutoras.

Fara as demais etapas da producăo observaram-se instalacóos que compreendem a creche, recria e terminacăo.

Os silos foram observados em $21 \%$ das propriedades, geralmence feitos de metal galvanizado, com capacidade média de 362 toneladas.

Na maioria das propriedades existe o depósito e fábrica de racăo. As outras instalacóes mencionadas foram: embarcadouro e esterqueira.

Os equipamentos especificos existentes săo: triturador, misturador de racăo, balancas para animais e racăo, lanca chamas, pulverizadores, alicates, seringas, geladeiras e carrinhos.

Equipamentos complementares: veiculos utilitários, caminhăo, trator, carretas, cacamba, tanque para puchar esterco, lava jato, mangueira, bombas $e$ motores. 
Região de Campinas - sub-região de Piracicaba

o municipio abrangido foi o de Firacicaba pertencente a lielegacia Agrjcola de firacicaba, da IIfiA de Campinas.

As principais atividades na llelegacia Agricola de Firacicaba săo: cana, milho, arroz, laranja, tangerina, feijăo da seca, mandioca e pastagem (CAKAfigo, 1983).

Em termos de IIIfiA têm-se: tomate envarado, tangerina, algodăo, laranja, limăo, batata das águas, batata da seca, batata de inverno, cebola, cana, uva, mandioca, arroz, milho, café e pastagem (CAMAfigo, 1983).

A Llelegacia de Firacicaba, em 1987, deteve $6,8 \%$ do rebanho suino da llira de Campinas

Caracteristicas gerais da propriedade e do proprietário:

A área média encontrada foi de 54 al queires. Nas propriedades em que a suinocultura representa a principal atividade (50\% da amostra) a area informada foi. de 7,6 alqueires e nas outras $50 \%$, em que a suinocultura participa com $75 \%$ da renda bruta, a área média girou em torno dos 100 alqueires, sendo as outras atividades mencionadas: bovinocultura, equinocultura emilho.

Quanto ao estágio de producăo, só $25 \%$ dos casos estudadas encontram-se en implantacaso, e os $75 \%$ restantes em producăo, sendo que destes uiltimos a situacăo em 
"

lientre os fatores limitantes, para o aumento dia

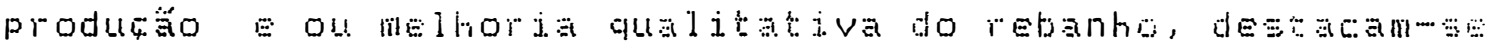
os referentes a felta de incentivos governamentsis para aumento da productóno de milho; preqos mujto altos dos principats insumos, inclusive milho; altos preios dos equipamentos; falta de financiamento para investimento; falta de máno-de-obra especializada.

Quanto ao tempo do proprietario na atjuidab: este variou entre 4 meses a 13 anos, e em termos medios 5,3 anos.

Informes sobre comercialização:

o sistema de vendas é fejto preponderadamente por peso vivo, havendo um desconto posterior de $20 \%$ para se chegar ao peso morto. o jistema de pacamento

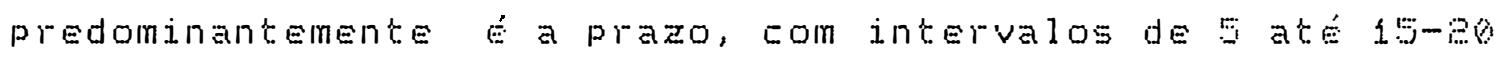
dias.

Quanto aos fatores utilizados pelo comprador

para estabelecer os pregos a serem pagos destacouse a item peso.

Como locais de comercializaroto, al sim das recibas proximas a zona produtora, foram mencionadas: Fio claro. Mogi. Mirime sáto Falo. 
Quanto ao custo de transporte de animais este

fica por conta do comprador, no entanto deve-se observar

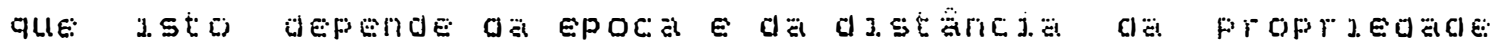
até o local de venda.

A venda de cevados é feita em grande parte para os frigoriticos.

\section{Dados de exploracão:}

Em 50\% da amostra os criadores săo de ciclo completo, 25\% săo terminadores de leităo e 25\% produtores de leităo e de reprodutores puros.

A composicăo do rebanho reprodutor (Tabela AR.3)

mostra que as racas Landrace large White săo as maj.s importantes no caso dos machos, destacando-se a landrace $e$ cruzamento entre racas para as fêmeas.

TABELA. AZ.3 - Composigăo Fiacial do Fiebanho, Fiegiăo de Firacicaba, Estado de Săo Faulo (em porcentagem)

$\begin{array}{lccccc}\text { Categoria } & \text { Luroc } & \text { Landrace } & \text { Large white } & \text { Cruzamento } \\ \text { Macho } & 20 & 40 & 40 & - \\ \text { Fêmea } & 5 & 34 & 24 & 37\end{array}$

Fonte: Llados da Fesquisa.

0 escalonamento da producăo é mensal, observando-se, entretanto, que no caso do terminador de: leităo apareceu também o esquema quinzenal 
0 numero total de fêmeas somou 453 animais $e$ os de macho 40, com variacóes de 30 a 124 animais, para o caso de femeas e 2 a 11 nos machos. A relacăo macholfêmea éde 1:11.

A porcentigem de descarte de matrizes e cachacos éde $25 \%$ ao ano.

\section{Índices médios de produtividade:}

1. Número de partos porta/ano = e, 16.

2. Número médio de leitóes nasc./parto = 11,16.

3. Numero de leitóes nascidos vivos/parto $=9,75$.

4. Forcentagem de mortes até o desmame = $17,1 . \%$.

5. Idade dos leitóges na desmama $=33,3$ dias.

6. J.dade média dos anjmais terminados $=5,5$ meses.

7. Idade média de venda de leitóes para recria = 65 dias.

8. Feso médio dos animais terminados $=86 \mathrm{~kg}$.

9. Feso médio dos animais descartados $=220 \mathrm{~kg}$.

Al iment ą̧ão:

Neste item observou-se que $25 \%$ da amostra estudada utiliza-se de superconcentrados e núcleos acrescidos de mitho (fubá), farelo de soja e farelo de trigo. Fara os demais constatou-se o uso de prémixes 
vitaminjcos-minerais, e nesses casos os ingrediences mencionados, de forma geral, pelos produtores săo, além do milho; farelo de trugo, tarelo de soja, farjuta de carne, fosfato bicálcio, sal, calcareo, leite, metionina, e: sulfato de cobre.

Como aditivos das razöes mencionaram-se: os vermifugos, antibióticos, quimioterápicos, etc.

Milho

Têm-se que $75 \%$ dos entrevistados compram todo 0 milho e só $25 \%$ produzem parte do milho consumido.

Quanto aos locais de aquisjcăo do milho, destacam---se as regiöes de ratui, Itapeva, Itararé e Firacicaba

Quanto à época de aquisiqăo tem-se que $75 \%$ compram na safra o restante(25\%) todo més.

A armazenagem do milho é feita em $50 \%$ das propriedades e acontece de forma ensacada.

Mão de obra:

o tipo de măo-de-obra utilizada na amostra estudada é a contratada, com salarios variando entre 1 a 1., 5 salários mínimos. 


\section{Higiene e profilaxia:}

As doencas mais comuns do rebanho săo: rinite atrófica, pneumoenterite, egastroenterite dos leitóses. Ds exames, incluem os de Brucelose, Aujeski e Leptospirose. As análises feitas săo de água componentes das racóos.

As vacinas mais usadas săo: Fieste Suina, Aftosa, Faratifo e contra Finite Atrófica.

Como medicamentos utilizados tem-se: vermifugos, ferro, antibióticos, sarnicidas, etc.

Instalacões e equipamentos:

A área para instalacoós de cachacos variou entre 9 a leme, implicando numa área média de lome.

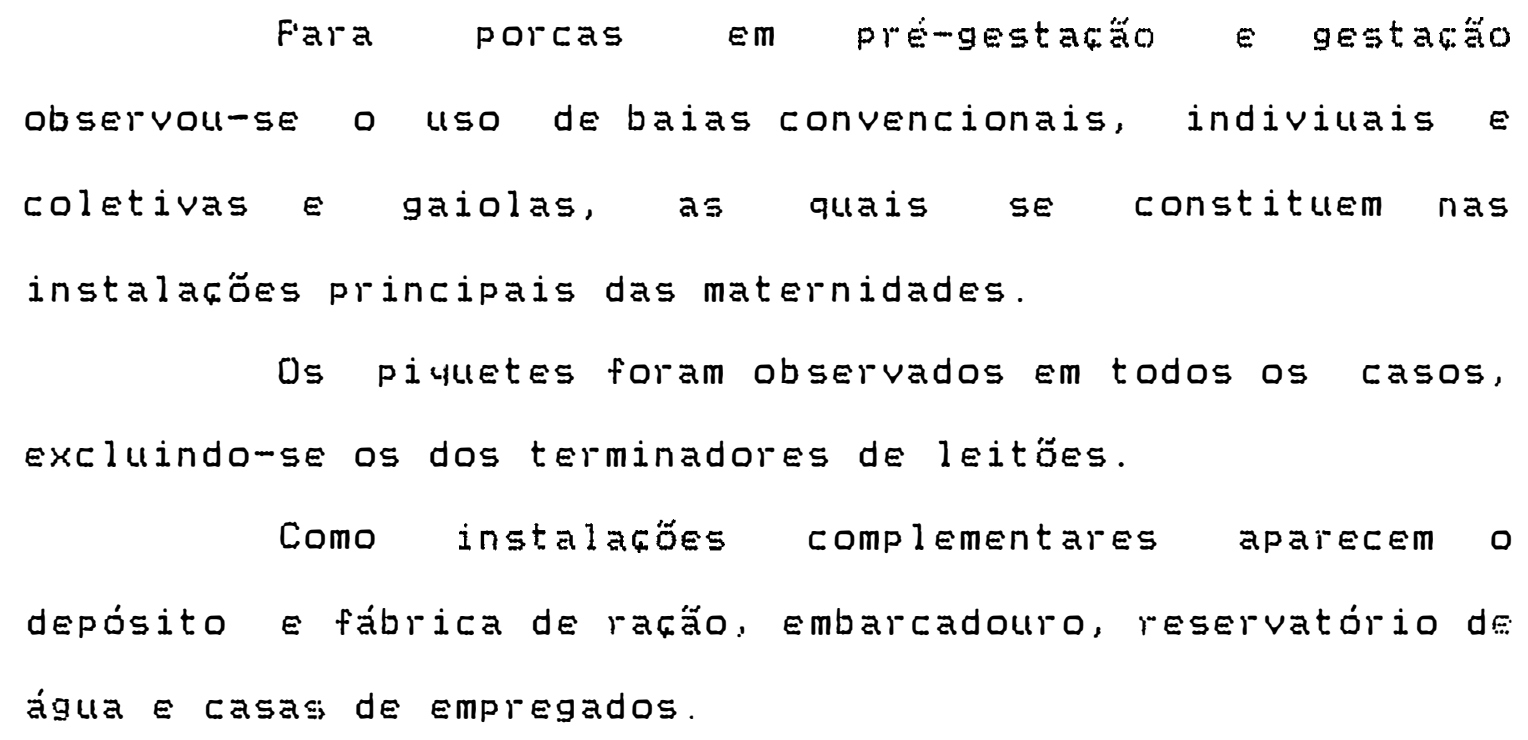


Ds equipamentos especificos incluem: trituracor, misturador de racăo, balanca para racăo, balanca para pesagem de animais, langa chamas, alicates, seringas, carrinhos, etc. Como equipamentos complementares destacaram-se: tanque para puxar esterco, bombas, motores, carreta, caminhăo, etc.

\section{Região de Sorocaba - sub-região de Avaré}

\section{Área de estudo:}

Os municipios constantes da pesquisa foram os de Cerqueira César e Taquarituba, ambos pertencentes a delegacia de Avaré, da llira de Sorocaba.

As principais atividades agricolas na rira de Sorocaba săo: feijăo (águas $e$ seca, inverno), cebola, tomate envarado, milho, tangerina, arroz, algodăo, trigo, Uva, soja e limăo, (CAMAFiGO, 1983).

Na llelegacia de Avaré (1) destacam-se: milho, fieijăo das águas, algodăo, soja, café, feijăo da seca, aroz, cana, trigo, batata (água $e$ seca) $e$ mandioca (CAMAFiGO, 1983).

Segundo o Instituto dé Economia Agricola, em 1987 a lira de Sorocaba deteve um rebanho de 283.046 (1) Nä pésquisa de Camargo (1983) a Il.A. de Avaré estava incluido na Sub-regiẫo de fibeirăo Vermelho do Sul. 
suinos, o que significa uma participacăo de 14,1.2\% em relacăo ao Estado. Na llelegacia de Avaré, encontra-se um efetivo de 44.996 animals, representando $15,90 \%$ do total detectado na lira de Sorocaba.

Caracteristicas gerais da propriedade e do proprietário:

A área total variou entre 1,5 a 17 alqueires o que resultou numa área média de 7,6 alqueires.

Verificou-se que em $25 \%$ das unidades da amostra a suinocultura é a cinica atividade com $100 \%$ de participacăo enquanto as $75 \%$ restantes, além de suinos exploram a bovinocultura e a cafeicultura, atividades estas que representam em média $20 \%$ da receita no total da propriedades.

lientre as empresas estudadas, têm-se que $25 \%$ retornavam a suinocultura, 50\% encontravam-se em expansăo

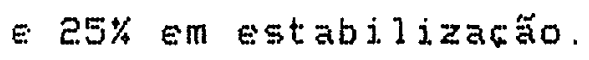

Os fatores mencionados como limitantes para aumento de producăo elou melhoria genética do rebanho foram: falta de milho na entressafra e falta de reprodutores.

o tempo dos empresários na atividade variou entre 5 meses (retornando) a 15 anos, e em média 9 anos. 
u sustema de venda preconizado na pesquisa tol o do peso vivo, com posterior desconto de 20* para o peso morto.

Em 1.00\% dos casos estudados o peso foi o fator mencionado para estabelecimento de precos.

Os locais de comercializacăo dos animais terminados incluem além da propria regiăo (Taquarituba E Cerqueira (ésar), regiöes vizjnhas e Săo Faulo.

Na venda dos animais, o transporte da propriedade at dos casos por conta do comprador, $e 25 \%$ a cargo do vendedor, que nesse caso vende parte da producăo em Săo Faulo.

Os agentes participantes da comercializacăo de suinos săo os intermediários, agougueiros, abetedouros $e$ frigorifj.cos sob Inspecăo Federal.

Dados de exploracăo

A finalidade das exploracóes é a venda de animais terminados, compreendendo todo o ciclo de producăo.

As racas predominantes săo a luroc, Landrace $e$ Large White para os machos e cruzamento entre racas para as fêmeas (Tabela A2.4). 
TABELA AE.4 - Composizăo fiacial do fiebanho, fiegjăo de

Sorocaba, Estado de Stro Fanto

(em porcentagem)

\begin{tabular}{|c|c|c|c|c|}
\hline & & & & $\begin{array}{c}\text { Cruzamento } \\
\text { entre }\end{array}$ \\
\hline Fiaca & linuroc & Landrace & Large White & racas \\
\hline Machos & 46,35 & 21,95 & 2.1. 95 & 9,75 \\
\hline Femeas & 8,26 & 8,26 & 3,30 & $80,5.8$ \\
\hline
\end{tabular}

Fonte: liados da Fiesquisa.

0 numero de fêmeas reprodutoras variou entre 15 a 480 , com 149 animais em termos médios. D rebanho de machos variou entre 2 a 30 , com uma média de 10 cachacos.

- rebanho de femeas somou bos animais e o de machos 41, o que implicou numa relacăo macho/femea de $1: 14,8$.

\section{Índices médios de produtividade}

1) Número de partos/porca/ano = e, 1.

2) Número de lej.tóes nascidos/parto $=1.0,75$.

3) Número de leitóes nascidos vivos/parto $=9$, 25 .

4) J.dade dos leitoes na desmama $=36,25$ dias.

5) Forcentagem de mortes até o desmame = $=6 \%$.

6) Idade de abate (meses) $=5,4$.

7) Feso no abate $=86,1 \mathrm{~kg}$.

8) Feso dos animais descartados =: $223,33 \mathrm{~kg}$. 
Aliment ą̧̃ăo

Em 25\% das propliedades a rąăo é compostă unicamente da mistura concentrado e milho. Nos outros $50 \%$ além do superconcentrado e núcleo observou-se a inclusăo de farelo de trigo e farelo de soja. Tambem detectou-se casos (25\%) de suinocultores que formulam racöes a partir de prémixes vitaminicosminerais adicionados ao milho, farelo de trigo, farelo de soja e fosfato.

\section{Milho}

llo milho utilizado na suinocultura somente $27 \%$ é produzido na propriedade, sendo o restante $63 \%$ adquirido na própria regiăo.

Quanto à época de aquisicao do milho os suinocultores costumam comprälo todo o mês, com mais intensidade na época da safra.

A forma de armazenagem do milho é a seguinte: $75 \%$ a granel e $25 \%$ ensacada; utilizando-se de armazéns próprios $(50 \%)$ e alugados $(50 \%)$. 
Mão de obra:

o tipo de măo de obra utilizada na suinocultura é a contratada, muito embora nas pequenas propriedades o:s donos participem dos trabalhos de conducăo da atividade.

Os salários variam entre il a 1,08 saláios minimos.

Higiene e profilaxia:

A doenca mais comum do rebanho E gastroenterite.

Quanto aos exames o mais usual \& o de brucelose, săo tamben feitos, com certa frequência, as análises de raqũอs $e$ fezes.

As vacinas mais utilizadas săo: Faratjfo, Fieste Suina e contra Finite Atrófica.

A vermifugacăo do rebanho e a aplicacăo do ferro nos leitóes săo práticas comuns. Além desses medicamentos observou-se o uso de antibióticos, poljujtaminj.cos, antidiarréicose sarnicidas. 
Insta]ąões e equipamentos:

Fara a categoria cachacos as instalacöes possuem área variando entre 8 a leme/cabega com area média de $6.75 m 2$.

Fara porcas em pré-gestacăo observou-se além do uso de baias convencionais o sistema de confinamento total em gajolas, o mesmo acontencendo nas instalacóes das maternidadss.

Quanto aos piquetes săo usados unicamente para as categorias machos e femeas reprodutoras.

0 silo só apareceu em 25\% dos casos e justamente nas grandes propriedades. o material empregado na construcăo é zinco galvanizado.

As outras instalacöes incluem o depósito, fábrica de racăo e casas de empregados.

Ds equipamentos especificos mencionados săo: triturador, misturador de racăo, balanfas, lanfa chamas, pulverizador, alicates, seringas e carrinhos.

Como equipamentos complementares tem-se: caminhonetes, carrinho, trator, carretas, tanque para puxar esterco, bombas, motores, etc. 
ANEXO 3. ESPECIFICACÃO DOS ITENS COMPONENTES DOS CUSTOS 
Ds precos dos fatores utilizados for am provenientes dos Levantamentos do Instituto de Economa Agricola, firmas, Sindicatos Associacóes de criadores, referentes ao mês de junho de 1988, como segue:

Animais de reproducão:

Fêmeas (7 meses) $=$ Cz\$ $29.000,00 /$ unidade

Machos ( 7 meses) $=$ Cz\$ $44.400,00 /$ unidade

Animais para abate:

Forco tipo carne = Cz\$2.208, 82/aroba

Animais de descarte (reprodutores) =

Cz\$1. $546,18 /$ arroba

Alimentos para racão e racão pronta:

Witho $=$ Cz\$ 1. $1.90,91.15 a c 060 \mathrm{~kg}$

Farelo de soja = Cz\$ $45,20 / \mathrm{kg}$

Farinha de carne $=C 2 \$ 35,62 / \mathrm{kg}$

Calcário $=$ Cz\$3,80/kg

Sal de cozinha $=$ Cz\$ $\$$ i.j, $00 / \mathrm{kg}$ 
Folivitaminico acabamento $=\mathrm{Cz} \$ 781,25 / \mathrm{kg}$

Folivitaminico reproducăo $=C z \$ 760,99 / \mathrm{kg}$

Concentiado crescimento $=\mathrm{Cz} 6 \%, 17 / \mathrm{kg}$

Concentrado engorda $=$ Cz\$56,26/kg

Concentrado reproducăo $=C z \$ 64,02 / \mathrm{kg}$

Fiąăo pré inicial = Cz\$ $56,84 / \mathrm{kg}$

Fiăăo inicial $=C z \$ 47,10 / \mathrm{kg}$

Racão formulada ao nivel de granja, à partir de polivitaminico:

Fiąăo inicial $=C z \$ 37,12 / \mathrm{kg}$

Fiąăo crescimento $=C z \$ 27,53 / \mathrm{kg}$

Fiąăo engorda $=C z \$ 23,90 / \mathrm{kg}$

Fiąăo reproducăo $=$ Cz\$ $23,58 / \mathrm{kg}$

Fiąăo lactąăo $=\operatorname{Cz} 24,68 / \mathrm{kg}$

Vacinas e medicamentos:

Vacina contra Feste Suina $=C z \$ 666,33 / f r a s c 0 d e$ $50 \mathrm{ml}$

Vacina contra Faratifo $=$ Cz\$ $54,85 / f r a s c 050 \mathrm{ml}$

Vermifugo injetável = Cz\$1.237,00/frasco de $250 \mathrm{ml}$

Ferro injetável $=$ Cz\$ $1.663,74 / f r a s c o$ de $1.00 \mathrm{~m}]$ 
Máquinas e equipamentos:

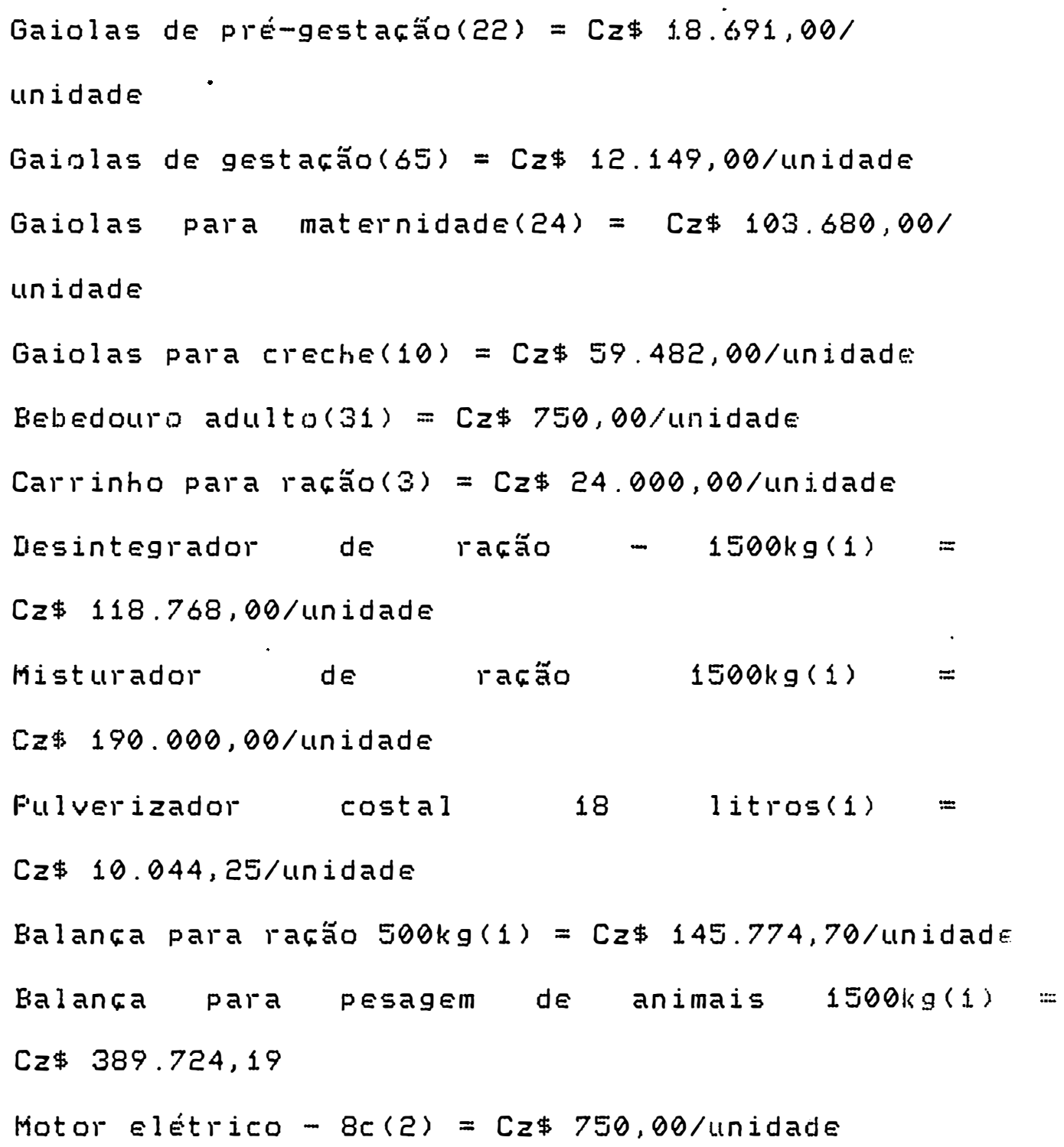


Benfeitorias e instalacões:

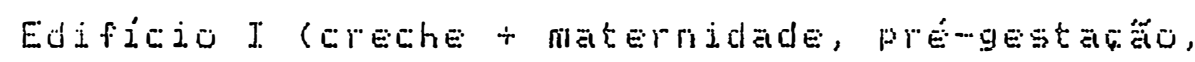
gestacăo $\quad$ cachacos $) \quad-. \quad(547,59 \mathrm{~m} 2) \quad:=$ $\mathrm{Cz} 8.867,70 / \mathrm{mL}$

Edificio II (recria-terminacao)-(605,00me) = $C 2 \$ 9.392,29 / \mathrm{m} 2$

Fieservatório de água - 3.600 ljtros = Cz\$ $1.396 .951,00$ (preqo total)

Casa de empregado $-60 \mathrm{~m} 2(2)=\mathrm{Cz} 23.563,43 / \mathrm{m} 2$ Llepósito fábica de racăo(110me) = C2\$ 11.520,80/m2

Ds valores dos imóveis foram calculados através da atualizacăo das planilhas de orcamento utilizadas pelo Eanco de llesenvolvimento do Estado de săo Faulo (BALESF), em projetos de investimento na suinocultura, compreendendo dados sobre a fundacăo, superestrutura, revestimento, piso, piscina, cobertura, instalacăo elétrica e instalacăo hidráuli.ca.

A atualizacăo foi feita acompanhando-se as cotacódes de materiais e servicos, registrados em junho de 1988 (data base de cálculo de custos) na revista "A Construcăo em Săo Faulo."

Os pregos para o reservatório de água, depósito e fábrica de racăo e escritório, foram obtidos através da conversăo dos valores constantes do projeto de REGAZZINI(1977), de fevereiro de 1977, para a data base, utilizando-se o indice FINI de custos e edificacö́s, 
publicado na revista citada.

Os valores das casas de empregados foram obtidos do Custo Lnitálo FINI de Edificacoes, também constante de "A Construcăo em Săo F'aulo".

Salários :

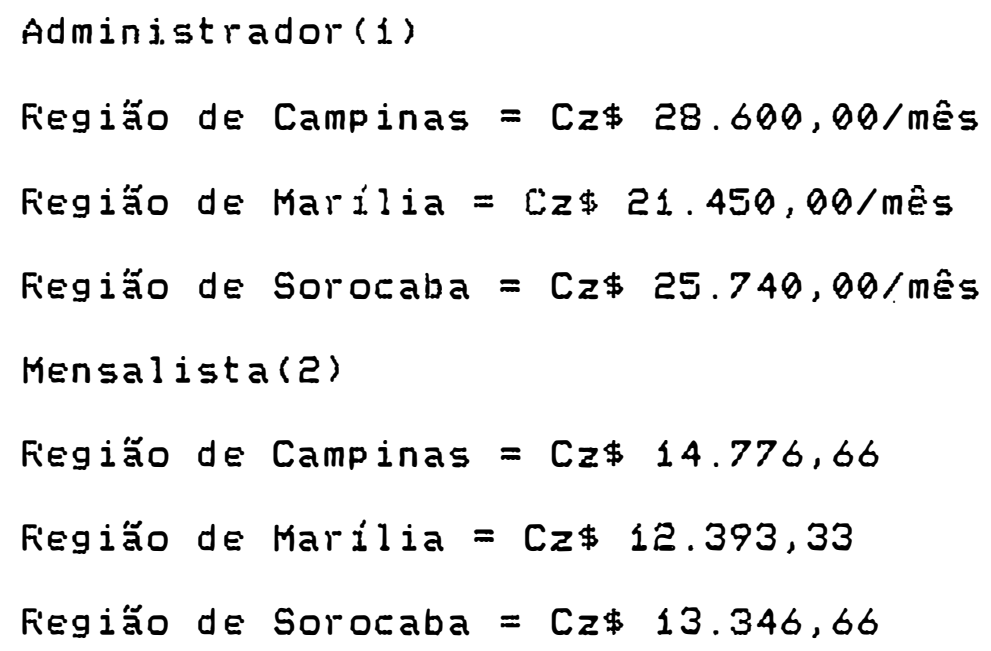

Terra(1ha):

Fiegiăo de Campinas = Cz\$ $92.200,00 / \mathrm{ha}$

Fiegiăo de Marilia $=C z \$ 44.600,00 / \mathrm{ha}$

Fiegiăo de Sorocaba $=C z \$ 56.700,00 / \mathrm{ha}$ 
ANEXO 4. MATRIZES PARA

DETERMINACÃO DOS CUSTOS, POR REGIÃO, E ESTIMATIUA DE UIDA ÚTIL DOS EQUIPAMENTOS 


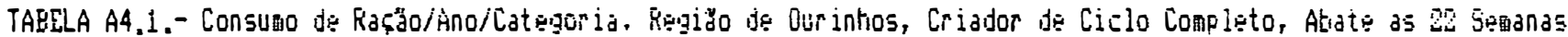
(E⿱一𫝀口亍i

\begin{tabular}{|c|c|c|c|c|c|}
\hline Sutegoniz & Ano 0 & $\sin 1$ & Anc 2 & $\ldots$ & $\operatorname{Mnc} 14$ \\
\hline Cactiaso & 3.724 & 5.096 & 5,096 & $\ldots$ & 5.096 \\
\hline Matriz $(1)$ & 48.720 & 58.240 & 52.240 & $\ldots$ & 50.240 \\
\hline Porca na Maternidade & 12.320 & 40.040 & 40.040 & $\ldots$ & 40.040 \\
\hline Leitao na Haternidade & 1.437 & 4.979 & 4.979 & $\ldots$ & 4.79 \\
\hline Leitäo na Cructie & 4.272 & 20.792 & 20.792 & $\ldots$ & 80.792 \\
\hline Leitäo na Recria & 10.312 & 107.295 & 107.295 & $\ldots$ & 10.275 \\
\hline Leitåo na Terainazỡo & 1.582 & 19.513 & 199.727 & $\ldots$ & 19.70 \\
\hline
\end{tabular}

(1) In:lui leitoa, poria vazia, píg-gestante ge gistante Fonte: Ilados da pesquisa 


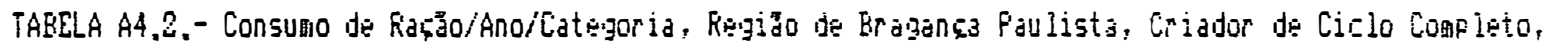
Ghate as 20 setianas

(EAi hig)

\begin{tabular}{|c|c|c|c|c|c|}
\hline Categoria & Ano 0 & Ang: & Ano 2 & $\ldots$ & Ano 14 \\
\hline Cothase & 3,724 & 5.98 & 500 & $\ldots$ & 5.096 \\
\hline Hatriz (1) & 48.720 & 58.240 & 58.240 & $\cdots$ & 58.240 \\
\hline F'orca na Maternidade & 12.320 & 40.040 & $40.67 \hat{0}$ & $\cdots$ & $40.04 \hat{0}$ \\
\hline Lẹitzo na Maternidade & 1.439 & 4.979 & 4.979 & $\ldots$ & 4.979 \\
\hline Leitảo na Croucher & 4.272 & 20.792 & 20.792 & $\ldots$ & 20.798 \\
\hline Leitgo na kecria & 10.312 & 107.295 & 107.295 & $\ldots$ & 107.295 \\
\hline Leitzo na Terminazäo & 1.682 & 230.510 & 237.641 & $\ldots$ & 237.641 \\
\hline
\end{tabular}

(1) Inclui leitoa, porca vazia, pri-gestante e gestante Fonte: liados da pesquisa 


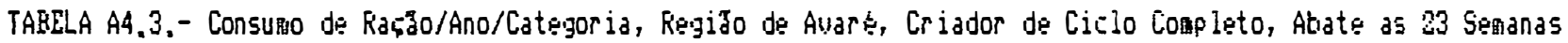
(Efi $\mathrm{kg}$ )

\begin{tabular}{|c|c|c|c|c|c|}
\hline Categoria & Ano 0 & Ano 1 & Ano 2 & $\ldots$ & ano 14 \\
\hline Carthaco & 3.724 & 5.096 & 5.096 & $\therefore$ & 5.096 \\
\hline Matriz (1) & 48,720 & 58.240 & 58.240 & $\ldots$ & 58.240 \\
\hline Forca na Haternidade & 12.320 & 40,040 & 40.040 & $\ldots$ & 40.040 \\
\hline Leit3o na haternidade & 1.401 & 4.848 & 4.848 & $\ldots$ & 4.848 \\
\hline Leitzo na Crectre & 4.398 & 21.403 & 21.403 & $n$ & 21,403 \\
\hline Leitgo na Recria & 10.312 & 107.295 & 107.295 & $\ldots$ & 107.295 \\
\hline 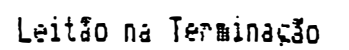 & 1.682 & 230.510 & 237.641 & $\ldots$ & 837.641 \\
\hline
\end{tabular}

(1) Inciui leitoa, poria vazia, pré-gestante e gestante Fonte: llados da pesquisa 
TARELA A4.4.- Consu解 de Raçăo/Ano/Categoria, Regizo de Piracicabia, Criador de Ciclo Coap lato, Abata dอ 3 sentanas

\begin{tabular}{|c|c|c|c|c|c|}
\hline Categuria & Ano 0 & Ano $\mathrm{I}$ & Hno & $\ldots$ & Ano $\mathrm{Ja}$ \\
\hline Cachiaso & 3.724 & 5.096 & 5.090 & $\ldots$ & 5,090 \\
\hline Matriz (1) & 90.700 & $58.24 \hat{7}$ & 5.240 & $\ldots$ & 80.940 \\
\hline Foría na Materiidade & 12.320 & 40.040 & 40.040 & $\ldots$ & 40.040 \\
\hline Leitgo na haternidade & 1.477 & 5.110 & 5.110 & $\ldots$ & 5.110 \\
\hline Leitáo na Creche & 4.398 & 21.403 & 21.403 & $\ldots$ & 21.403 \\
\hline Leitgo na fectia & 10.312 & 107.295 & 107.295 & $\ldots$ & 107.295 \\
\hline Lieitao na Ter minaşäo & 1.682 & 230.510 & 237.641 & $\ldots$ & 237.641 \\
\hline
\end{tabular}

(1) Inclui leitoa, porca vazia, pre-gestante gestante Fonte: llados da pesquisa 


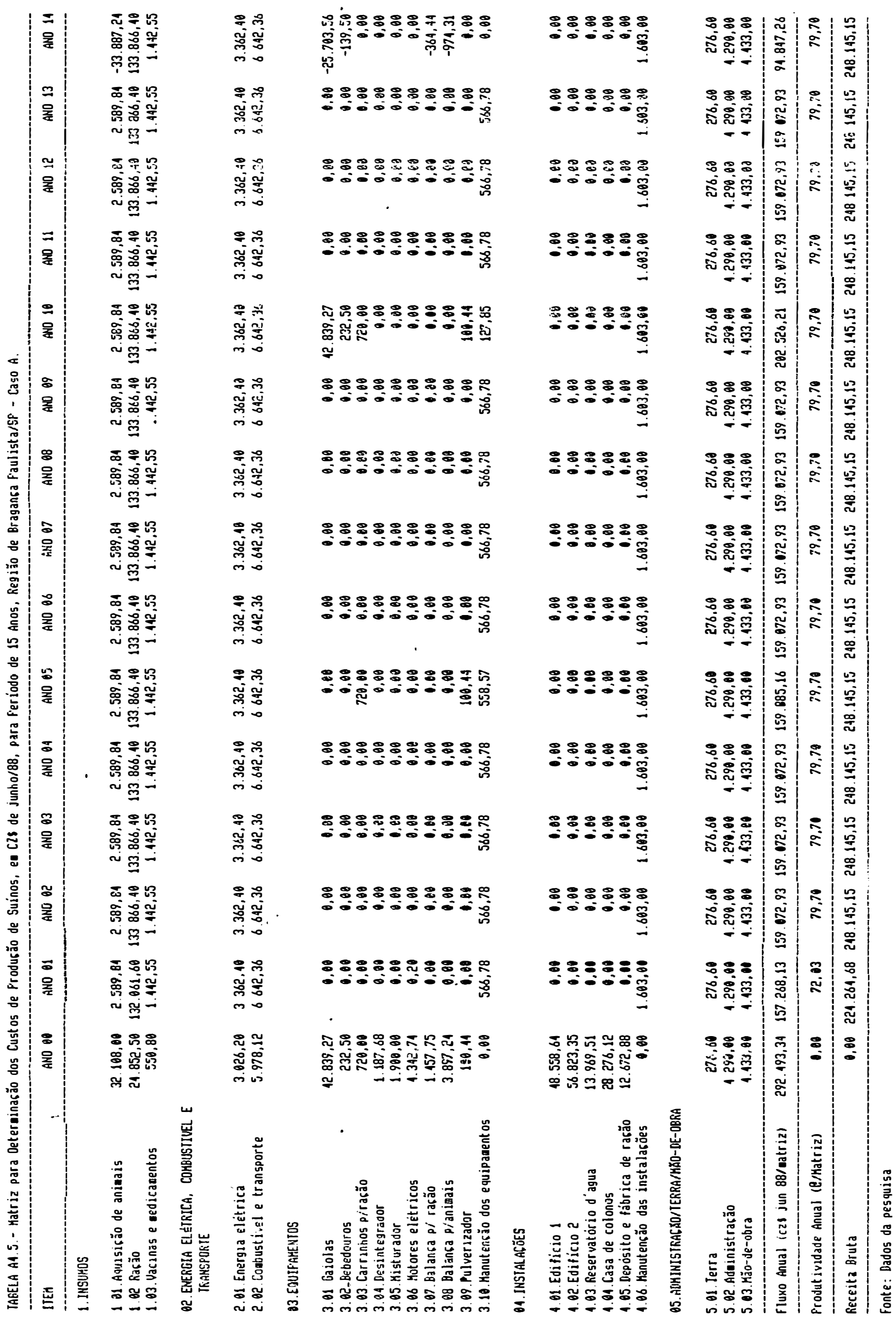




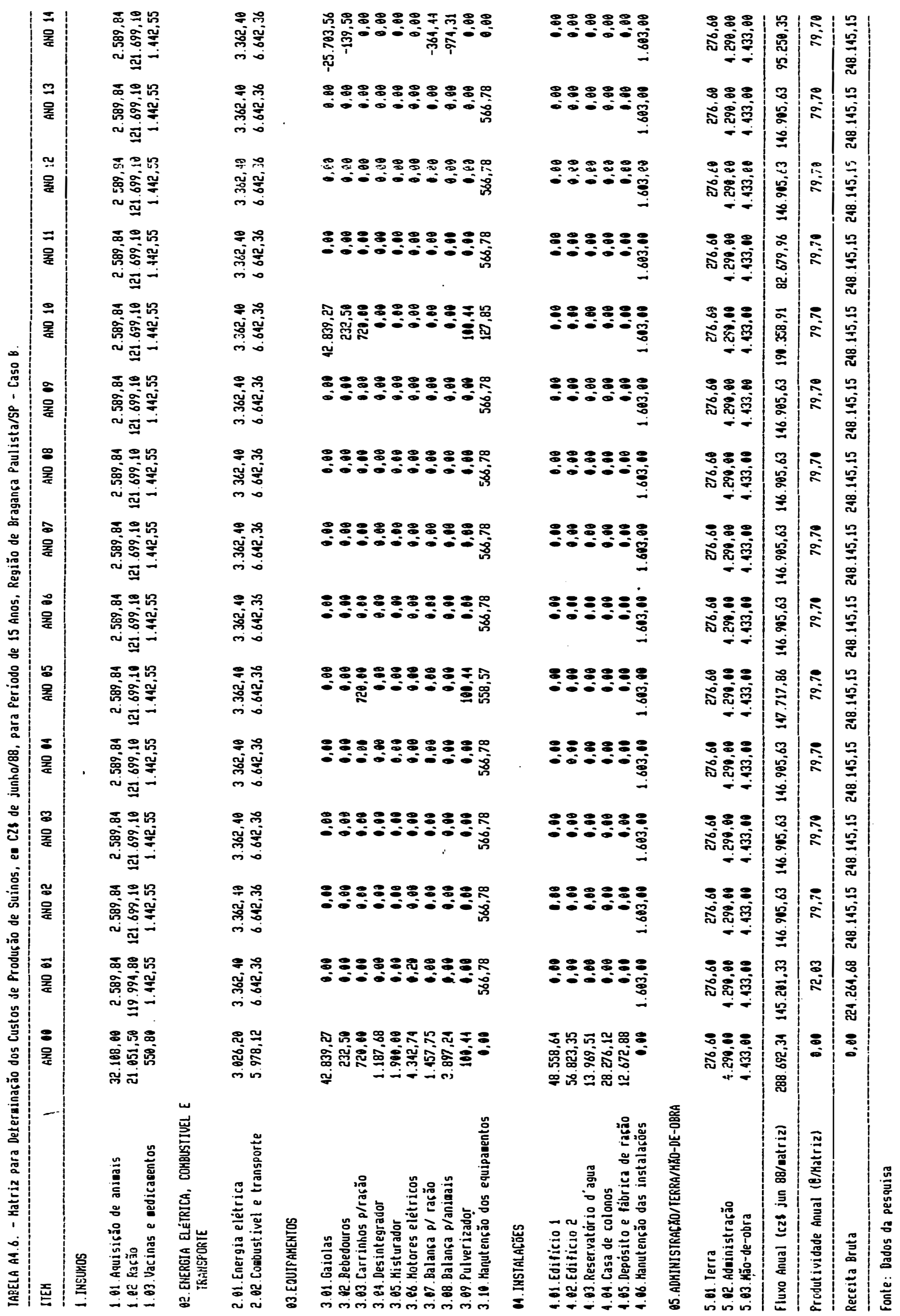




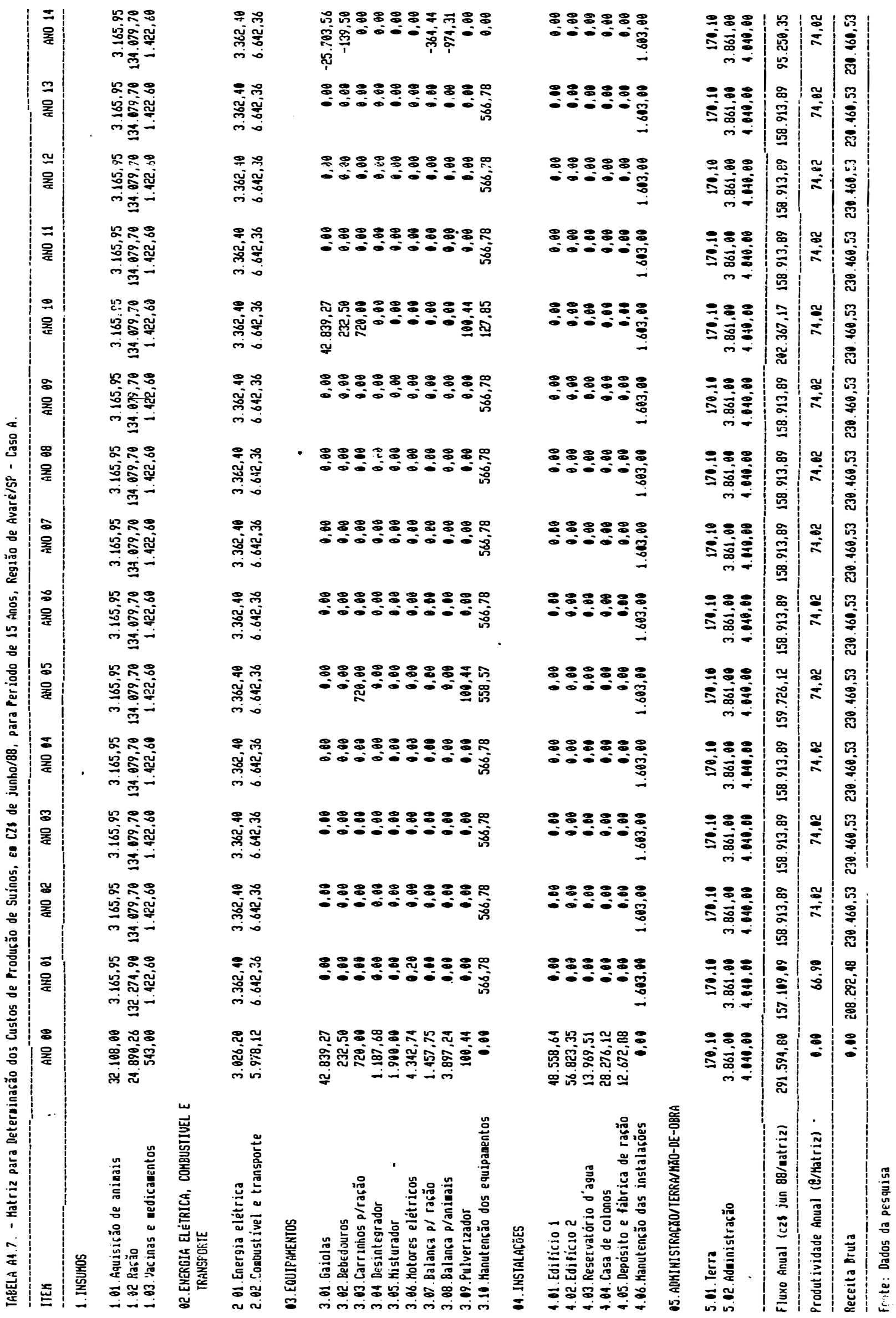




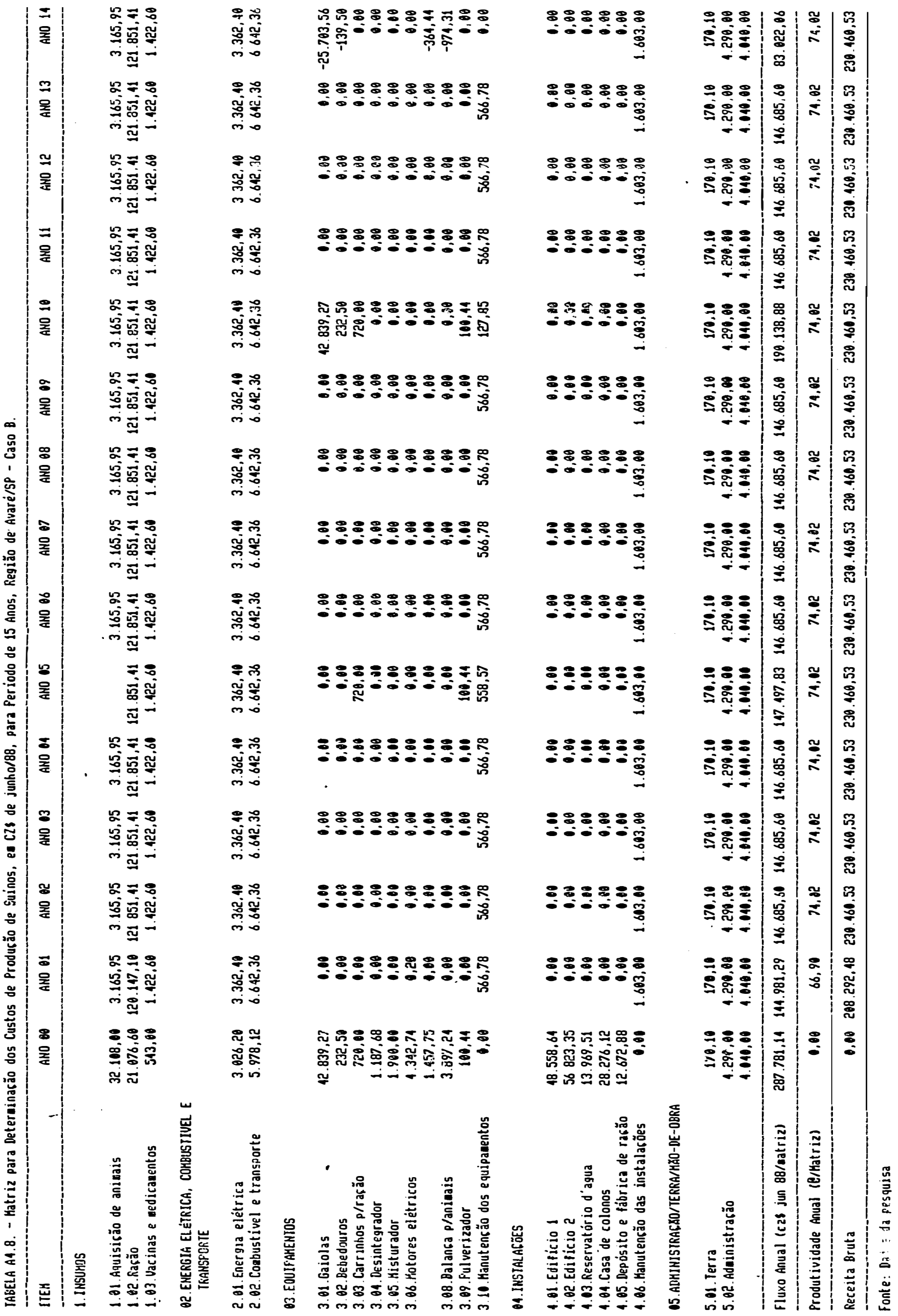




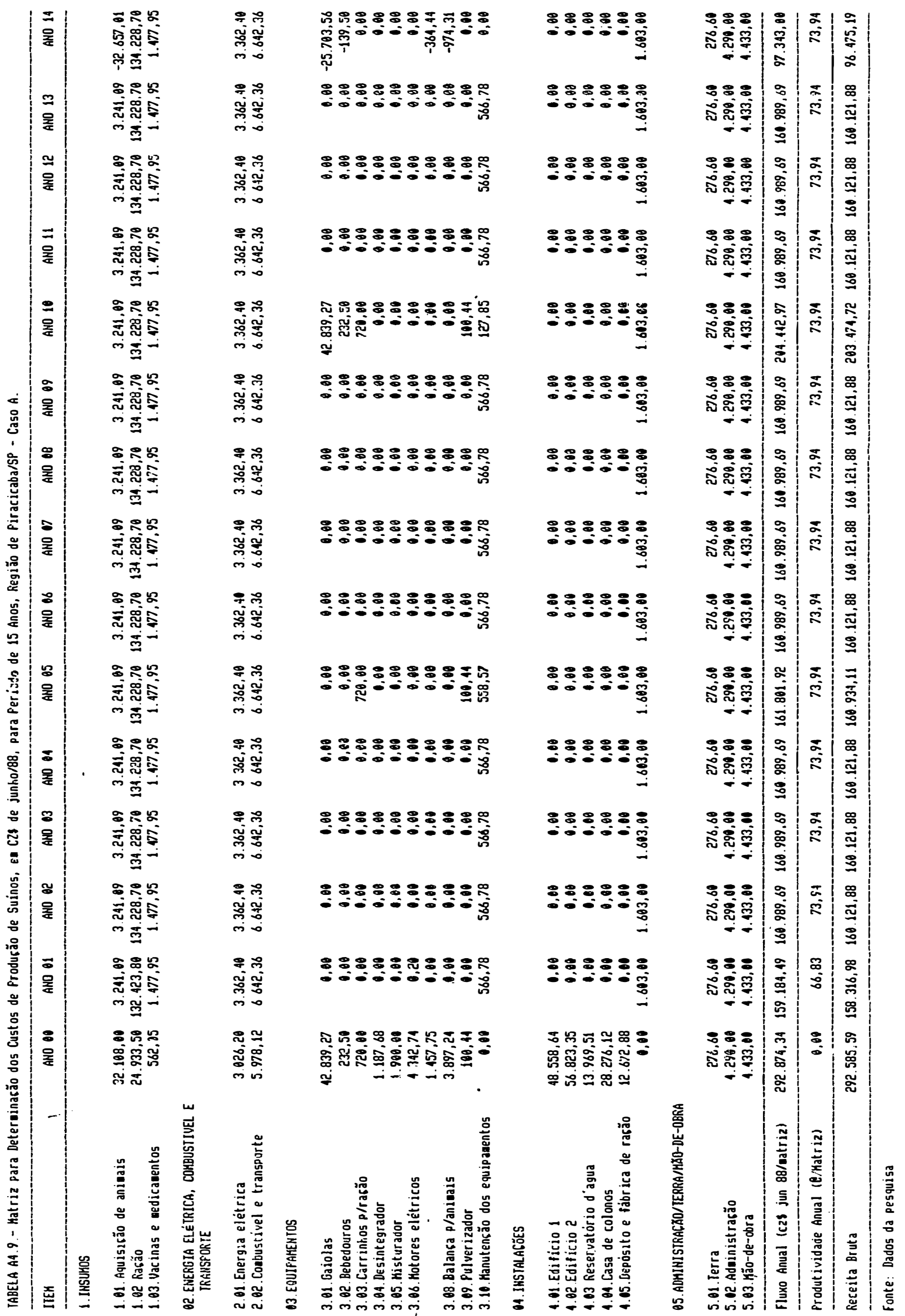




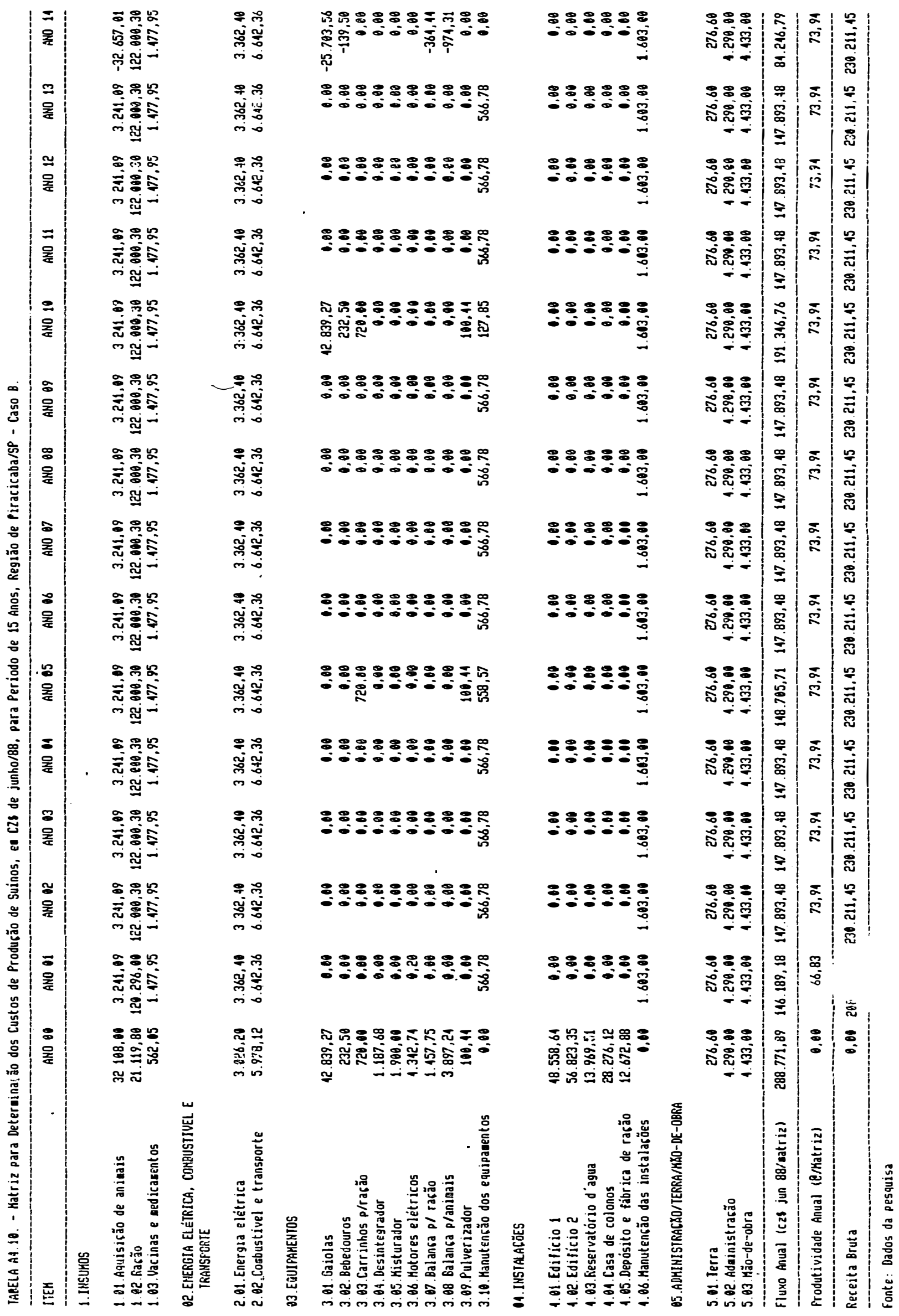




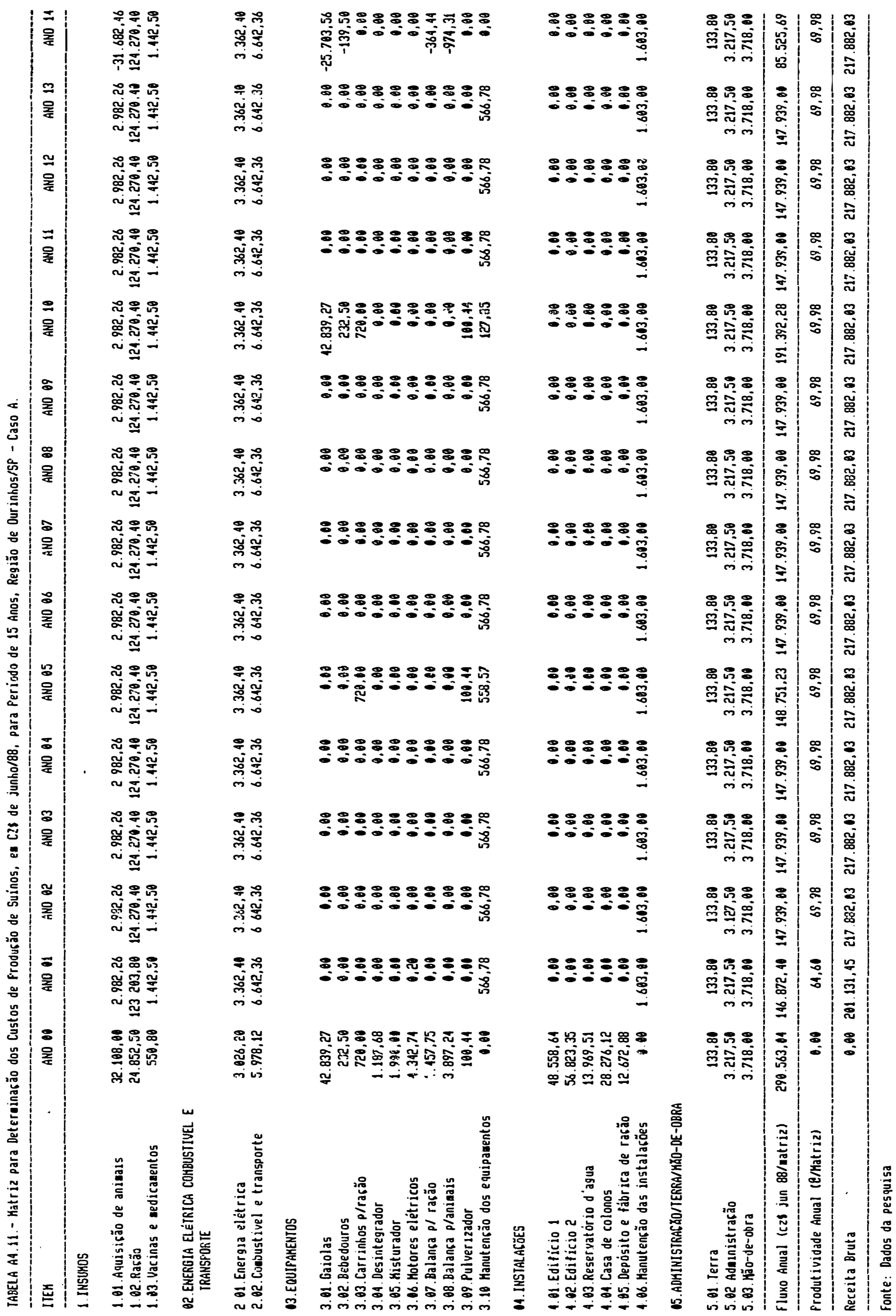




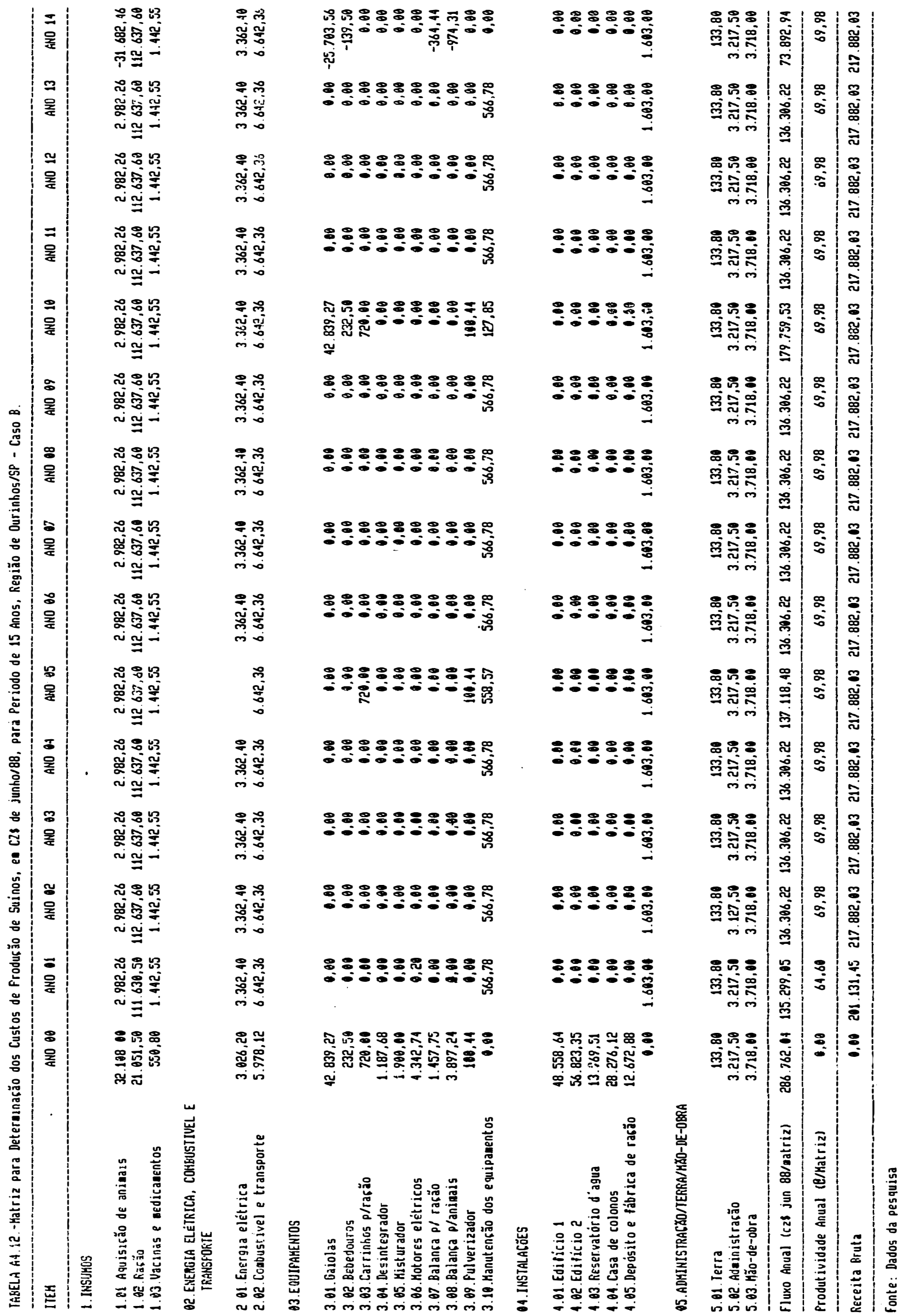


TABELA A4.13.- Estimativa de vida Util dos Equipamentos \& Instalacăes Números de anos

\begin{tabular}{lr}
\hline Casas de eupregados e depósito & 50 \\
Instalacöes de animais & 30 \\
Balancas & 20 \\
Kisturadores de racăo & 15 \\
Gaiolas & 10 \\
Bebedouro & 10 \\
Kotores elétricos & 15 \\
Desintegradores & 15 \\
-
\end{tabular}

Fonte: Dados da pesquisa; HOFFHANN et alii (1976) e Sá (1985) 


\begin{abstract}
ANEXO 5. ELEMENTOS DA ANÁLISE
DE RENTABILIDADE DA PRODUGÃO DE SUÍNOS, POR REGIÃO, ESTADC DE SÃO PAULO
\end{abstract}


TABELA A5.1.-Elegentos da Análise de Rentatilidade da Frodusło de Suinos, Regizo de Our inhos, Caso A (1)

\begin{tabular}{rrr} 
Beneficios & Custos & Fluxo Liquido \\
\hline 0,0 & $290.563,0$ & $-290.563,0$ \\
$201.131,4$ & $146.872,4$ & $54.259,0$ \\
$217.882,0$ & $147.939,0$ & $69.943,0$ \\
$217.882,0$ & $147.939,0$ & $69.943,0$ \\
$217.882,0$ & $147.939,0$ & $69.943,0$ \\
$217.882,0$ & $148.751,2$ & $69.130,8$ \\
$217.882,0$ & $147.939,0$ & $69.943,0$ \\
$217.882,0$ & $147.939,0$ & $69.943,0$ \\
$217.882,0$ & $147.939,0$ & $69.943,0$ \\
$217.882,0$ & $147.939,0$ & $69.943,0$ \\
$217.882,0$ & $191.392,3$ & $26.489,7$ \\
$217.882,0$ & $147.939,0$ & $69.943,0$ \\
$217.882,0$ & $147.939,0$ & $69.943,0$ \\
$217.882,0$ & $147.939,0$ & $69.943,0$ \\
$217.882,0$ & $85.525,7$ & $132.356,3$ \\
\hline-20 &
\end{tabular}

(1) Custo de oportunidade: 10,00\%

Fonte: llados da pesquisa 
TABELA A5.2.- Elementos da Análise de Rentatiilidade da Froducăo de Sulnos, Regizo de Ourinhros, Caso B (1)

\begin{tabular}{rrr} 
Beneficios & Custos & Fluxo Liquido \\
\hline 0,0 & $286.762,0$ & $-284.268,6$ \\
$210.131,4$ & $135.299,1$ & $65.832,3$ \\
$217.882,0$ & $136.306,2$ & $81.575,8$ \\
$217.882,0$ & $136.306,2$ & $81.575,8$ \\
$217.882,0$ & $136.306,2$ & $81.575,8$ \\
$217.882,0$ & $137.118,5$ & $80.763,6$ \\
$217.882,0$ & $136.306,2$ & $81.575,8$ \\
$217.882,0$ & $136.306,2$ & $81.575,8$ \\
$217.882,0$ & $136.306,2$ & $81.575,8$ \\
$217.882,0$ & $136.306,2$ & $81.575,8$ \\
$217.882,0$ & $179.759,5$ & $38.122,5$ \\
$217.882,0$ & $136.306,2$ & $81.575,8$ \\
$217.882,0$ & $136.306,2$ & $81.575,8$ \\
$217.882,0$ & $136.306,2$ & $81.575,8$ \\
$217.882,0$ & $73.892,9$ & $143.989,1$ \\
$-\cdots$ & &
\end{tabular}

(1) Custo de oportunidade: $10,00 \%$

Fonte: Dados da pesquisa 
TABELA A5.3.- Eleventos da Análise de Rentabilidade da Produszo de Suinos, Regizo de Auare, Caso A'(1)

\begin{tabular}{|c|c|c|}
\hline Beneflcios & Custos & Fluxo LIquido \\
\hline 0,0 & $291.594,8$ & $-291.594,8$ \\
\hline $208,292,5$ & $157.109,1$ & $51,183,4$ \\
\hline $230,460,5$ & $158.913,9$ & $71,546,6$ \\
\hline $230.460,5$ & $158.913,9$ & $71,546,6$ \\
\hline $230,460,5$ & $158,913,9$ & $71,546,6$ \\
\hline $230,460,5$ & $159,726,1$ & $70,734,4$ \\
\hline $230,460,5$ & $158,913,9$ & $71.546,6$ \\
\hline $230,460,5$ & $158,913,9-$ & $71,546,6$ \\
\hline $230,460,5$ & $158,913,9$ & $71,546,6$ \\
\hline $230,460,5$ & $158,913,9$ & $71.546,6$ \\
\hline $230,460,5$ & $202.367,2$ & $28.093,4$ \\
\hline $230,460,5$ & $158,913,9$ & $71.546,6$ \\
\hline $230,460,5$ & $158.913,9$ & $71.546,6$ \\
\hline $230.460,5$ & $158,913,9$ & $71.546,6$ \\
\hline $230.460,5$ & $95.250,3$ & $135.210,2$ \\
\hline
\end{tabular}

(1) Custo de oportunidade: 10,00\%

Fonte: llados da pesquisa 
TABELA A5.4.- Elementos da Análise de Rentabilidade da Frodusăo de Suinos, Regiao de Auart, Caso B (1)

\begin{tabular}{rrr}
\hline Beneficios & Custos & Fluxo Liquido \\
\hline 0,0 & $287.781,1$ & $-287.781,1$ \\
$208.292,5$ & $144.981,3$ & $63.311,2$ \\
$230.460,5$ & $146.685,6$ & $83.774,9$ \\
$230.460,5$ & $146.685,6$ & $83.774,9$ \\
$230.460,5$ & $146.685,6$ & $83.774,9$ \\
$230.460,5$ & $147.497,8$ & $82.962,7$ \\
$230.460,5$ & $146.685,6$ & $83.774,9$ \\
$230.460,5$ & $146.685,6$ & $83.774,9$ \\
$230.460,5$ & $146.685,6$ & $83.774,9$ \\
$230.460,5$ & $146.685,6$ & $83.774,9$ \\
$230.460,5$ & $190.138,9$ & $40.321,7$ \\
$230.460,5$ & $146.685,6$ & $83.774,9$ \\
$230.460,5$ & $146.685,6$ & $83.774,9$ \\
$230.460,5$ & $146.685,6$ & $83.774,9$ \\
$230.460,5$ & $83.022,1$ & $147.438,5$ \\
\hline$-\cdots$ & &
\end{tabular}

(1) Custo de oportunidade: $10,00 \%$

Fonte: Iados da pesquisa 
TABELA A5.5.- Elezentos da Análise de Rentabilidade da Froduszo de Suinos, Regizo de Braganca Faulista, Caso A (S)

\begin{tabular}{rrr}
\hline Eeneficios & Custos & Fluxo Liquido \\
\hline 0,0 & $292.493,3$ & $-292.493,3$ \\
$224.264,7$ & $157.268,1$ & $66.996,5$ \\
$248,145,1$ & $159.072,9$ & $89.072,2$ \\
$248,145,1$ & $159.072,9$ & $89.072,2$ \\
$248,145,1$ & $159.072,9$ & $89.072,2$ \\
$248,145,1$ & $159.885,2$ & $88.260,0$ \\
$248,145,1$ & $159.072,9$ & $89.072,2$ \\
$248,145,1$ & $159.072,9$ & $89.072,2$ \\
$248,145,1$ & $159.072,9$ & $89.072,2$ \\
$248,145,1$ & $159.072,9$ & $89.072,2$ \\
$248,145,1$ & $202.526,2$ & $45.618,9$ \\
$248,145,1$ & $159.072,9$ & $89.072,2$ \\
$248,145,1$ & $159.072,9$ & $89.072,2$ \\
$248.145,1$ & $159.072,9$ & $89.072,2$ \\
$248.145,1$ & $94.847,3$ & $153.297,9$ \\
$-\cdots--1$ &
\end{tabular}

(1) Custo de oportunidade: $10,00 \%$

Fonte: llados da pesquisa 
TARELA A5.6.- Elementos da Análise de Rentatiilidade da Producta de Suinos, Regizo de Er agania Fiaulista, Caso B (1)

\begin{tabular}{|c|c|c|c|}
\hline Eenefleios & Custos & & Fluxo Liquido \\
\hline 0,0 & $288,692,3$ & & $-288,692,3$ \\
\hline $224.264,7$ & $145.201,3$ & & $79.063,3$ \\
\hline $248,145,1$ & $146,905,6$ & & $101.239,5$ \\
\hline $248,145,1$ & $146.905,6$ & & $101.239,5$ \\
\hline $248,145,1$ & $146.905,6$ & & $101,239,5$ \\
\hline $248,145,1$ & $147,717,9$ & & $100,427,3$ \\
\hline $248,145,1$ & $146,905,6$ & $\nu$ & $101.239,5$ \\
\hline $248,145,1$ & $146,905,6$ & - & $101.239,5$ \\
\hline $248,145,1$ & $146.905,6$ & & $101,239,5$ \\
\hline $248,145,1$ & $146,905,6$ & & $101,239,5$ \\
\hline $248,145,1$ & $190.358,9$ & & $57.786,2$ \\
\hline $248,145,1$ & $146.905,6$ & & $101.239,5$ \\
\hline $248,145,1$ & $146,905,6$ & & $101.239,5$ \\
\hline $248,145,1$ & $146.905,6$ & & $101.239,5$ \\
\hline $248,145,1$ & $82,680,0$ & & $165.465,2$ \\
\hline
\end{tabular}

(1) Custo de oportunidade: 10,00\%

fonte: lados da pesquisa 


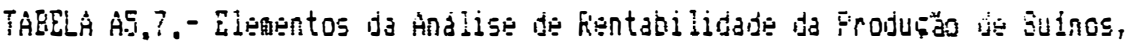

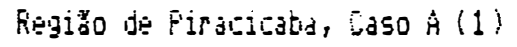

\begin{tabular}{|c|c|c|}
\hline inefl:ios & Custos & Fluxo Lfquidi \\
\hline 2,0 & $292.585,6$ & $-298.385, \dot{0}$ \\
\hline $208,074,5$ & $159.317,0$ & 49.797 .5 \\
\hline $230.211,4$ & $600.121,9$ & $70.989,5$ \\
\hline $230,211,4$ & $160,121,9$ & 70.089 .5 \\
\hline $230.211,4$ & $100,121,9$ & $70.689,5$ \\
\hline $230,211,4$ & $160.934,1$ & $50,077_{1}=$ \\
\hline $230.211,4$ & $160.121, ?$ & $70,089,5$ \\
\hline $230.211,4$ & $100,12 j, 9$ & $70.08 \%, 5$ \\
\hline $230,211,4$ & $160,121,9$ & $70,089,5$ \\
\hline $230.211,4$ & $160.121, ?$ & $70,087,5$ \\
\hline $230,211,4$ & $203,474,7$ & $26.736,7$ \\
\hline $230,21 i, 4$ & $160,121,9$ & $70.089,5$ \\
\hline $230,211,4$ & $160,121,9$ & $70.089,5$ \\
\hline $230,211,4$ & $100,121,9$ & $70,909,5$ \\
\hline $230,211,4$ & $96.175,2$ & $13,73,8$ \\
\hline
\end{tabular}

(1) Custo de oportunidade: 10,00\%

Fonte: iladus da pesquisa 
TABELA A5.8.- Eleaentos da Análise de Rentabilidade da Firoducáo de Suinos, Regizo de Firacicala, Caso B (1)

\begin{tabular}{rrr}
\hline Beneficios & Custos & Fluxo Liquido \\
\hline 0,0 & $288.771,9$ & $-288.771,9$ \\
$208.074,5$ & $146.189,2$ & $61.885,4$ \\
$230.211,4$ & $147.893,5$ & $82.318,0$ \\
$230.211,4$ & $147.893,5$ & $82.318,0$ \\
$230.211,4$ & $147.893,5$ & $82.318,0$ \\
$230.211,4$ & $148.705,7$ & $81.505,7$ \\
$230.211,4$ & $147.893,5$ & $82.318,0$ \\
$230.211,4$ & $147.893,5$ & $82.318,0$ \\
$230.211,4$ & $147.893,5$ & $82.318,0$ \\
$230.211,4$ & $147.893,5$ & $82.318,0$ \\
$230.211,4$ & $191.346,8$ & $38.864,7$ \\
$230.211,4$ & $147.893,5$ & $82.318,0$ \\
$230.211,4$ & $147.893,5$ & $82.318,0$ \\
$230.211,4$ & $147.893,5$ & $82.318,0$ \\
$230.211,4$ & $84.246,8$ & $145.964,7$ \\
$-\cdots--.-1$ &
\end{tabular}

(1) Custo de oportunidade: 10,00\%

Fonte: Dados da pesquisa 